\title{
REVISION 1
}

\section{Atomic arrangements around the $\mathrm{O3}$ site in $\mathrm{Al}$ - and $\mathrm{Cr}$-rich oxy- tourmalines: a combined EMP, SREF, FTIR and Raman study}

\author{
Ferdinando Bosi ${ }^{1,2}$, Henrik Skogby ${ }^{2}$, Peter Lazor $^{3}$ and Leonid Reznitskii ${ }^{4}$
}

${ }^{1}$ Dipartimento di Scienze della Terra, Sapienza Università di Roma, Piazzale Aldo Moro, 5, I-00185 Rome, Italy

${ }^{2}$ Department of Geosciences, Swedish Museum of Natural History, Box 50007, SE-10405 Stockholm, Sweden

${ }^{3}$ Department of Earth Sciences, Uppsala University, SE-752 36 Uppsala, Sweden

${ }^{4}$ Institute of the Earth's Crust, Siberian Branch, Russian Academy of Science, Lermontova str., 128, 664033 Irkutsk, Russia

Corresponding author:

Ferdinando Bosi, e-mail: ferdinando.bosi@uniroma1.it, tel: +39 0649914901, fax: +39 064454729

\begin{abstract}
A study of natural oxy-tourmalines belonging to the system oxy-dravite chromo-alumino-povondraite - oxy-chromium-dravite from the Sludyanka crystalline complex (Southern Baikal region, Russia) was carried out to explore the characteristic vibrational bands in the principal $(\mathrm{OH})$-stretching frequency and their relations to the $\mathrm{O} 3$
\end{abstract}


anion site of the tourmaline structure. Relevant information was obtained using electron microprobe analysis (EMPA), structural refinement (SREF), infrared (IR) and Raman single crystal spectroscopy. The studied oxy-tourmalines are characterized by the substitution $\mathrm{Al} \leftrightarrow \mathrm{Cr}$ which is accompanied by redistribution of $\mathrm{Mg}$ over the $Y$ and $Z$ sites. The occurrence of strong correlations between relative peak area intensities for two IR bands at 3565 and $3519 \mathrm{~cm}^{-1}$ and cation site populations derived from SREF and EMP data allowed assignment of the band at $3565 \mathrm{~cm}^{-1}$ to the cluster $\left[{ }^{\mathrm{Y}} \mathrm{Mg}^{\mathrm{Z}} \mathrm{Al}{ }^{\mathrm{Z}}(\mathrm{Al}, \mathrm{Mg})\right]-\mathrm{O} 3$ and the band at $3519 \mathrm{~cm}^{-1}$ to the cluster $\left.\left[{ }^{\mathrm{Y}} \mathrm{Cr}^{\mathrm{Z}}(\mathrm{Cr}, \mathrm{Al}){ }^{\mathrm{Z}}(\mathrm{Cr}, \mathrm{Al}, \mathrm{Mg})\right)\right]-\mathrm{O} 3$.

It appears that the combination of polarized IR and Raman spectra collected with the electric vector $\mathbf{E} \perp \mathbf{c}$ and $\mathbf{E} / / \mathbf{c}$ may provide a useful characterization of the local $(\mathrm{OH})$ environments around the $\mathrm{O} 3$ site of the tourmaline structure.

Keywords Tourmaline, Electron microprobe, Crystal structure refinement, Infrared spectroscopy, Raman spectroscopy, Short-range arrangement

\section{Introduction}

Tourmalines are complex borosilicates and their crystal structure and crystal chemistry have been extensively studied (e.g., Foit 1989; Ertl et al. 2002; Hawthorne and Henry 1999; Bosi et al. 2010; Lussier et al. 2011; Filip et al. 2012; Cempírek et al. 2013). In accordance with Henry et al. (2011), the general formula of tourmaline may be written as: $X Y_{3} Z_{6} T_{6} \mathrm{O}_{18}\left(B \mathrm{O}_{3}\right)_{3} V_{3} W,{ }^{[9]} X=\mathrm{Na}^{+}, \mathrm{K}^{+}, \mathrm{Ca}^{2+}, \square$ (=vacancy); ${ }^{[6]} Y=\mathrm{Al}^{3+}, \mathrm{Fe}^{3+}, \mathrm{Cr}^{3+}, \mathrm{V}^{3+}$, $\mathrm{Mg}^{2+}, \mathrm{Fe}^{2+}, \mathrm{Mn}^{2+}, \mathrm{Li}^{+} ;{ }^{[6]} Z=\mathrm{Al}^{3+}, \mathrm{Fe}^{3+}, \mathrm{Cr}^{3+}, \mathrm{V}^{3+}, \mathrm{Mg}^{2+}, \mathrm{Fe}^{2+} ;{ }^{[4]} T=\mathrm{Si}^{4+}, \mathrm{Al}^{3+}, \mathrm{B}^{3+} ;{ }^{[3]} B=$ $\mathrm{B}^{3+} ; V\left(\equiv{ }^{[3]} \mathrm{O} 3\right)=(\mathrm{OH})^{1-}, \mathrm{O}^{2-} ; W\left(\equiv{ }^{[3]} \mathrm{O} 1\right)=(\mathrm{OH})^{1-}, \mathrm{F}^{1-}, \mathrm{O}^{2-}$.

Vibrational transitions in the $(\mathrm{OH})$-stretching region has been presented for tourmaline in a number of studies (e.g., Gonzalez-Carreño et al. 1988; Castañeda et al. 2000; Hoang et al. 2011; Fantini et al. 2014). For elbaite, Skogby et al. (2012) presented a unifying assignment model for observed $(\mathrm{OH})$ stretching bands using a combination of 
long-range information (based on diffraction techniques) and short-range information (based on spectroscopic techniques).

In this paper, we use a similar approach to explore the infrared (IR) and Raman spectra in the wavenumber region $3000-4000 \mathrm{~cm}^{-1}$ of six single crystals of oxy-tourmalines belonging to the solid solution system oxy-dravite - chromo-alumino-povondraite - oxychromium-dravite, and present a model to link the vibrational bands to stable short-range arrangements supported by bond-valence constraints.

\section{Samples}

The samples used in this study (T89104, Tmt6b, PR85v, Tm1p43e, PR107 and PR108) are macroscopically emerald green and comes from metaquartzites in the Pereval marble quarry, Sludyanka crystalline complex, Southern Baikal region, Russia. At this locality (see Bosi et al. 2012a for a more detailed description), Cr-V-bearing metamorphic rocks are associated with $\mathrm{Cr}-\mathrm{V}$-bearing diopside and tremolite, escolaite, uvarovite, chromite, $\mathrm{V}$ bearing titanite, pyrite, barite and calcite together with euhedral and subhedral crystals of tourmaline. The host-rock consists of a lens (10-15 cm thickness) of greenish-grey medium-grained quartzite within the marbles of the Pereval quarry. The crystals are euhedral, reaching up to $0.3 \mathrm{~mm}$ in length, and are often chemically zoned. However, homogeneous crystals also occur, and were selected for the present study.

Four of the six studied oxy-tourmalines (samples Tmt6b, PR85v, Tm1p43e and PR107) have previously been structurally and chemically characterized by means of X-ray single-crystal diffraction, electron microprobe analysis and Mössbauer spectroscopy. Moreover, samples PR85v and PR107 were also characterized by means of IR and optical absorption spectroscopy (Bosi et al. 2004; Bosi et al. 2013; Reznitskii et al. 2014). The obtained structural and chemical information revealed a chemical composition corresponding to the chromo-alumino-povondraite species with a variation predominantly in the $\mathrm{Al}$ and $\mathrm{Cr}$ contents. In order to cover the major compositional range characterized by the $\mathrm{Cr}$ for $\mathrm{Al}$ substitution, an oxy-dravite sample (PR108) and an oxy-chromium-dravite (T89104) was also structurally and chemically characterized. These samples were also characterized by IR and Raman single crystal spectroscopy (for details, see Table 1). 


\section{Experimental methods}

\section{Single-crystal structural refinement}

Two representative crystals of oxy-dravite (sample PR108) and oxy-chromium-dravite (sample T89104) were selected for X-ray diffraction measurements on a Bruker KAPPA APEX-II single-crystal diffractometer, at Sapienza University of Rome (Earth Sciences Department), equipped with a CCD area detector $\left(6.2 \times 6.2 \mathrm{~cm}^{2}\right.$ active detection area, 512 $\times 512$ pixels) and a graphite crystal monochromator, using MoKa radiation from a finefocus sealed X-ray tube. The sample-to-detector distance was $4 \mathrm{~cm}$. A total of 3265 (for PR108) and 1469 (for T89104) exposures ( $\mathrm{step}=0.2^{\circ}$, time $/ \mathrm{step}=20 \mathrm{~s}$ ) covering the full reciprocal sphere with a redundancy of about 10 (for PR108) and 6 (for T89104). Final unit-cell parameters were refined with the Bruker AXS SAINT program using reflections with $I>10 \sigma(I)$ in the range $5^{\circ}<2 \theta<70^{\circ}$. The intensity data were processed and corrected for Lorentz, polarization, and background effects with the APEX2 software program of Bruker AXS. The data were corrected for absorption using the multi-scan method (SADABS). The absorption correction led to a significant improvement in $R_{\text {int. No }}$ violations of $R 3 m$ symmetry were noted.

Structural refinement was done with the SHELXL-2013 program (Sheldrick 2013). Starting coordinates were taken from Bosi et al. (2014). Variable parameters were: scale factor, extinction coefficient, atom coordinates, site scattering values and atom displacement factors. In detail, the $X$ site was modeled by using the Na scattering factor; the $Y$ site was modeled with $\mathrm{Cr}$ and $\mathrm{Mg}$ scattering factors; the occupancy of the $Z$ site was modeled with $\mathrm{Al}$ scattering factor for sample PR108, and $\mathrm{Cr}$ and $\mathrm{Mg}$ scattering factors for sample T89104. The $T$ and $B$ sites were modeled, respectively, with $\mathrm{Si}$ and $\mathrm{B}$ scattering factors and with a fixed occupancy of 1, because refinement with unconstrained occupancies showed no significant deviations from this value. Three full-matrix refinement cycles with isotropic displacement parameters for all atoms were followed by anisotropic cycles until convergence was attained. No significant correlations over a value of 0.7 between the parameters were observed at the end of refinement. Table 2 lists crystal data, 
data-collection information and refinement details; Table 3 gives the fractional atom coordinates and site occupancies; Table 4 gives the displacement parameters; Table 5 gives selected bond distances.

\section{Electron microprobe analysis}

Electron-microprobe analyses of the crystals used for X-ray diffraction refinement were obtained by wavelength-dispersive spectrometry (WDS mode) with a Cameca SX50 instrument at the "Istituto di Geologia Ambientale e Geoingegneria (Rome, Italy), CNR", operating at an accelerating potential of $15 \mathrm{kV}$, a sample current of $15 \mathrm{nA}$, and a $10 \mu \mathrm{m}$ beam diameter. Minerals and synthetic compounds were used as standards: wollastonite $(\mathrm{Si}, \mathrm{Ca})$, magnetite $(\mathrm{Fe})$, rutile $(\mathrm{Ti})$, corundum $(\mathrm{Al})$, vanadinite $(\mathrm{V})$ fluorphlogopite $(\mathrm{F})$, periclase $(\mathrm{Mg})$, jadeite $(\mathrm{Na}), \mathrm{K}$-feldspar $(\mathrm{K})$, sphalerite $(\mathrm{Zn})$, metallic $\mathrm{Cr}$, $\mathrm{Mn}$ and $\mathrm{Cu}$. Peak interferences of $\mathrm{V} \mathrm{K} \beta$ on $\mathrm{Cr} \mathrm{K} \alpha$ and $\mathrm{Ti} \mathrm{K} \beta$ on $\mathrm{V} \mathrm{K} \alpha$ were corrected and the PAP routine were applied (Pouchou and Pichoir 1991). The results (Table 6) represent mean values of 10 spot analyses. In accord with the very low concentration of Li in dravitic samples (e.g., Henry et al. 2011) and the crystallization environment of the studied sample (i.e., Crbearing metaquartzites), the $\mathrm{Li}_{2} \mathrm{O}$ content was assumed to be insignificant. The elements $\mathrm{Mn}, \mathrm{Fe}, \mathrm{Cu}$, and $\mathrm{Zn}$ were below the detection limits $(0.03 \mathrm{wt} \%)$ in the studied sample.

\section{Single crystal infrared spectroscopy}

Representative crystals of the four tourmaline samples that had not previously been studied were measured by Fourier transform infrared (FTIR) spectroscopy to characterize their $(\mathrm{OH})$ vibrational absorption bands. The spectrometer system consisted of a Bruker Equinox 55 spectrometer in conjunction with a Biorad infrared microscope, using a halogen lamp source, a $\mathrm{CaF}_{2}$ beam-splitter, a wire-grid polarizer (KRS-5) and an MCT detector. The crystals were oriented by morphology and optical microscopy, mounted on glass plates in thermoplastic resin and polished on two parallel sides, including the c-axis direction. Polarized absorption spectra were then acquired with a resolution of $4 \mathrm{~cm}^{-1}$ in the wavenumber range $2000-5000 \mathrm{~cm}^{-1}$ parallel and perpendicular to the crystallographic c-axis direction, using rectangular measurement areas of ca. $50 \times 50 \mu \mathrm{m}$ on the $26-50 \mu \mathrm{m}$ thick 
crystals. Sample Tmt6b that was available in slightly larger crystal size was mounted on a $100 \mu \mathrm{m}$ pin-hole aperture and was measured in the sample compartment of the spectrometer system using the same set-up, except for an InSb detector. As typically observed for tourmaline samples, the main $(\mathrm{OH})$ absorption bands polarized parallel the caxis direction were exceedingly intense, and it was not possible to thin the samples sufficiently to avoid off-scale absorption intensity for the strongest bands. Spectra obtained perpendicular to c-axis direction were analyzed by band-fitting using the Jandel PeakFit 4.12 software.

\section{Single crystal Raman spectroscopy}

Raman spectra were recorded on five representative single crystals using a spectroscopic system built at the Department of Earth Sciences, Uppsala University. The key system components include a high-throughput, single stage imaging spectrometer (HoloSpec f/1.8i, Kaiser Optical Systems, Inc.) equipped with a holographic transmission grating and a thermoelectrically cooled $\left(-60^{\circ} \mathrm{C}\right) \mathrm{CCD}$ detector (Newton, Andor Technology, $1600 \times 400$ pixels), a diode-pumped laser (Samba by Cobolt AB, $532.42 \mathrm{~nm}, 150 \mathrm{~mW} \mathrm{CW}$ ), and an optical imaging system (magnification $20 \times$, spatial resolution $\sim 1 \mu \mathrm{m}$ ). Two notch filters (Ondax Inc.) blocked the Rayleigh line. Polarized Raman spectra in parallel and perpendicular c-axis directions $\left(\mathrm{n}_{\varepsilon}\right.$ and $\left.\mathrm{n}_{\omega}\right)$ were collected in the back-scattering geometry at a resolution and accuracy of about $2 \mathrm{~cm}^{-1}$ and $1.5 \mathrm{~cm}^{-1}$, respectively. Typical acquisition time varied between 1 and 4 minutes, applying $15 \mathrm{~mW}$ of the laser power on the doublypolished parallel-plate oriented single crystals.

\section{Results}

\section{Determination of atomic proportions}

In agreement with the structural-refinement results, the boron content was assumed to be stoichiometric in samples PR108 and T89104 $\left(\mathrm{B}^{3+}=3.00 \mathrm{apfu}\right)$. Both the site-scattering results and the bond lengths of $B$ and $T$ are consistent with the $B$ site fully occupied by 
boron and no amount of $\mathrm{B}^{3+}$ at the $T$ site (e.g., Hawthorne 1996; Bosi and Lucchesi 2007). The $(\mathrm{OH})$ content can then be calculated by charge balance with the assumption $T+Y+Z$ $=15.00$ (e.g., Henry and Dutrow 1996). The atomic proportions were calculated on this assumption (Table 6). The excellent match between the number of electrons per formula unit (epfu) derived from chemical and structural analysis supports this procedure, respectively: 240.6 and 240.0 epfu for sample PR108, 279.3 and 279.4 epfu for sample T89104.

\section{Site populations}

The anion site populations in the studied samples follow the general preference suggested for tourmaline (e.g., Grice and Ercit 1993; Henry et al. 2011): the O3 site (V position in the general formula) is occupied by $(\mathrm{OH})^{1-}$ and $\mathrm{O}^{2-}$; the $\mathrm{O} 1$ site $(\mathrm{W}$ position in the general formula) is occupied by $\mathrm{O}^{2-},(\mathrm{OH})^{1-}$ and $\mathrm{F}^{1-}$. The cation distribution at the $T, Y$ and $Z$ sites was optimized by using a quadratic program to minimize the residuals between calculated and observed data (based on the chemical and structural analysis). Site-scattering values, octahedral and tetrahedral mean bond-distances (i.e., $\langle Y-\mathrm{O}\rangle,\langle Z-\mathrm{O}\rangle$ and $\langle T-\mathrm{O}\rangle$ ) were calculated as the linear contribution of each cation multiplied by its ideal bond-distance. More details about the ideal distances as well as the optimization procedure may be found in Bosi et al. (2004) and Bosi and Lucchesi (2004; 2007). The robustness of this approach was confirmed by another optimization procedure (Wright et al. 2000), which led to very similar cation distributions (Table 7). The final structural formulae for samples PR108 and T89104 are reported in Table 8 along with those of the previously studied samples Tmt6b, PR85v, Tm1p43e, and PR107 for comparison reasons. In accordance with the classification of Henry et al. (2011) and the findings of Bosi and Skogby (2013) and Bosi et al. (2012a), samples PR108 and T89104 can be classified, respectively, as oxy-dravite and oxychromium-dravite.

\section{Infrared and Raman spectra}

The IR spectra obtained parallel to the c-axis direction of the tourmaline samples are characterized by a strong absorption feature in the $3450-3600 \mathrm{~cm}^{-1}$ range (Fig. 1a) which is 
truncated due to exceedingly strong absorption, in line with previous studies (e.g., Bosi et al. 2012b, Skogby et al. 2012). Weak bands occur in the $3700-3800 \mathrm{~cm}^{-1}$ region, and are also polarized in the c-axis direction. Although a slight shift in position of the main absorption feature is apparent, any possible fine structures are obscured by the off-scale intensity recorded along the $\mathbf{c}$-axis. However, spectra polarized perpendicular to the $\mathbf{c}$-axis are much less intense and reveal two partly overlapping bands with systematic variation of their absorption intensities (Fig. 1b). This trend is associated with sample composition, where the band at higher wavenumbers increases with decreasing $\mathrm{Cr}$ content. In order to characterize and quantify these intensity shifts, the spectra were fitted with a model using two bands with variable absorption intensities, similar but variable band widths, and with band centres fixed at 3519 and $3565 \mathrm{~cm}^{-1}$. The band centres were initially obtained by unconstrained fits of spectra of the most Al-rich sample (PR108) and the most Cr-rich sample (T89104), which are both dominated by one of these bands. Completely unconstrained fits of all spectra were also tried, but were abandoned because the low band resolution for the spectra of the intermediate compositions caused unsystematic drift of the band centres. The obtained absorption area distributions for the two bands are listed in Table 9.

For the excitation wavelength, Raman spectra in the $(\mathrm{OH})$-region are characterized by a strong red fluorescence decreasing the signal-to-noise-ratio. This precluded spectral acquisitions for sample with the highest Al-content (PR108) for which the effect was most pronounced. Raman spectra obtained for electric field (E) direction parallel to the c-axis (E // c) are shown in Fig. 2. The overall appearance of spectra as well as their evolution upon varying Al-Cr content resembles that of infrared absorption for the perpendicular configuration $(\mathbf{E} \perp \mathbf{c})$ when the above-described two-band fitting model is applied. Positions of bands of the most Cr-rich sample (T89104) were used for all compositions when fitting the Raman spectra. The low quality of the spectrum for the Al-rich sample PR107 (Fig. 2) translated into a larger fitting uncertainty. The absorption area distributions for the two bands are listed in Table 9. A somewhat lower value of position of the $3556 \mathrm{~cm}^{-}$ ${ }^{1}$ Raman band, as compared to the corresponding $3565 \mathrm{~cm}^{-1}$ IR band, likely originates from comparing the spectra of different polarizations, parallel Raman (E // c) versus perpendicular IR $(\mathbf{E} \perp \mathbf{c})$, and from the fitting uncertainties. No Raman bands in the $(\mathrm{OH})$ region were observed for the configuration $\mathbf{E} \perp \mathbf{c}$. 


\section{Discussion}

\section{Crystal chemistry}

The six samples used for this study can be referred to the following ideal formulae:

- oxy-chromium-dravite, $\mathrm{Na}^{\mathrm{Y}} \mathrm{Cr}_{3}{ }^{\mathrm{Z}}\left(\mathrm{Cr}_{4} \mathrm{Mg}_{2}\right)\left(\mathrm{Si}_{6} \mathrm{O}_{18}\right)\left(\mathrm{BO}_{3}\right)_{3}(\mathrm{OH})_{3} \mathrm{O}$;

- chromo-alumino-povondraite, $\mathrm{Na}^{\mathrm{Y}} \mathrm{Cr}_{3}{ }^{\mathrm{Z}}\left(\mathrm{Al}_{4} \mathrm{Mg}_{2}\right)\left(\mathrm{Si}_{6} \mathrm{O}_{18}\right)\left(\mathrm{BO}_{3}\right)_{3}(\mathrm{OH})_{3} \mathrm{O}$;

- oxy-dravite, $\mathrm{Na}^{\mathrm{Y}}\left(\mathrm{Al}_{2} \mathrm{Mg}\right)^{\mathrm{Z}}\left(\mathrm{Al}_{5} \mathrm{Mg}\right)\left(\mathrm{Si}_{6} \mathrm{O}_{18}\right)\left(\mathrm{BO}_{3}\right)_{3}(\mathrm{OH})_{3} \mathrm{O}$.

They all have the $X$ site dominated by $\mathrm{Na}(0.68-0.98 \mathrm{apfu})$ with minor amount of $\mathrm{Ca}$, vacancies and $\mathrm{K}$. The $T$ site is dominated by $\mathrm{Si}$ (5.95-5.99 apfu) along with very minor amounts of $\mathrm{Al}$. The $\mathrm{O} 1$ site is dominated by $\mathrm{O}^{2-}(\sim 0.7 \mathrm{apfu})$, followed by $\mathrm{F}(0.1-0.3 \mathrm{apfu})$ and then by $(\mathrm{OH})$ (up to $0.3 \mathrm{apfu}$ ). The main compositional variation is characterized by the substitution of $\mathrm{Al}$ for $\mathrm{Cr}^{3+}$ at both the $Y$ and $Z$ sites (Fig. 3). In detail, moving from oxychromium-dravite to chromo-alumino-povondraite and further to oxy-dravite, ${ }^{\mathrm{Y}} \mathrm{Al}$ increases from zero to 0.65 apfu and ${ }^{\mathrm{Z}} \mathrm{Al}$ from 1.80 apfu to 4.33, whereas ${ }^{\mathrm{Y}} \mathrm{Cr}$ decreases from 2.55 to 0.63 apfu and ${ }^{\mathrm{Z}} \mathrm{Cr}$ from 2.23 to 0.33 apfu. Minor amounts of $\mathrm{V}^{3+}(<0.3$ apfu) are also present, alternatively at the $Y$ and $Z$ site. Minor amounts of $\mathrm{Fe}^{3+}(\sim 0.3$ apfu) are present at the $Z$ site only for sample PR107. The presence of $\mathrm{Mg}$ increases from 0.27 to 1.33 apfu at $Y$, whereas it decreases from 1.96 apfu to 1.34 apfu at $Z$ in accordance with the orderdisorder reaction between $R^{3+}$-cations and $\mathrm{Mg}$ at the $Y$ and $Z$ sites (see below). With respect to the ideal formulae, the observed octahedral site populations can chiefly be described by the ideal substitutions that follow:

oxy-chromium-dravite $\leftrightarrow$ chromo-alumino-povondraite

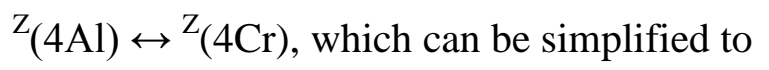

$$
\mathrm{Z}_{(\mathrm{Al})} \leftrightarrow^{\mathrm{Z}_{(}}(\mathrm{Cr})
$$

chromo-alumino-povondraite $\leftrightarrow$ oxy-dravite

$$
\begin{aligned}
& { }_{(3 \mathrm{Cr})}{ }^{\mathrm{Z}}(4 \mathrm{Al}+\mathrm{Mg}) \leftrightarrow{ }^{\mathrm{Y}}(2 \mathrm{Al}+\mathrm{Mg})+{ }^{\mathrm{Z}}(5 \mathrm{Al}) \text {, which can be simplified to } \\
& { }^{\mathrm{Y}}(3 \mathrm{Cr})+{ }^{\mathrm{Z}}(\mathrm{Mg}) \leftrightarrow{ }^{\mathrm{Y}}(2 \mathrm{Al}+\mathrm{Mg})+{ }^{\mathrm{Z}}(\mathrm{Al})
\end{aligned}
$$


The substitution of $\mathrm{Al}$ for $\mathrm{Cr}$ is accompanied by redistribution of $\mathrm{Mg}$ over the $Y$ and $Z$ sites, which can be summarized by the substitutions occurring along the oxy-chromium-dravite oxy-dravite join:

$$
\begin{aligned}
& { }^{\mathrm{Y}}(3 \mathrm{Cr})+{ }^{\mathrm{Z}}(4 \mathrm{Cr}+2 \mathrm{Mg}) \leftrightarrow{ }^{\mathrm{Y}}(2 \mathrm{Al}+\mathrm{Mg})+{ }^{\mathrm{Z}}(5 \mathrm{Al}+\mathrm{Mg}) \text {, which can be simplified to } \\
& \mathrm{Y}(3 \mathrm{Cr})+{ }^{\mathrm{Z}}(4 \mathrm{Cr}+\mathrm{Mg}) \leftrightarrow{ }^{\mathrm{Y}}(2 \mathrm{Al}+\mathrm{Mg})+{ }^{\mathrm{Z}}(5 \mathrm{Al})
\end{aligned}
$$

\section{Short-range arrangements around $\mathrm{Ol}$ and $\mathrm{O} 3$}

Short-range bond-valence requirements around the O1 site in tourmaline (Hawthorne 1996, 2002; Bosi 2010, 2011, 2013) invoke the occurrence of the following possible and stable short-range arrangements for the studied samples:

$$
\begin{aligned}
& \mathrm{Y}(\mathrm{Mg}+\mathrm{Mg}+\mathrm{Mg})-{ }^{\mathrm{O} 1}(\mathrm{OH}, \mathrm{F}), \\
& \mathrm{Y}\left(\mathrm{Mg}+\mathrm{Mg}+R^{3+}\right)-{ }^{\mathrm{O} 1}(\mathrm{OH}, \mathrm{F}), \\
& \mathrm{Y}\left(\mathrm{Mg}+R^{3+}+R^{3+}\right)-{ }^{\mathrm{O} 1}\left(\mathrm{O}^{2-}\right), \\
& \mathrm{Y}\left(R^{3+}+R^{3+}+R^{3+}\right)-{ }^{\mathrm{O} 1}\left(\mathrm{O}^{2-}\right)
\end{aligned}
$$

where $(\mathrm{OH}, \mathrm{F})$ correspond to two different $\mathrm{O} 1$-site arrangements and $R^{3+}=\mathrm{Al}, \mathrm{Cr}$ and $\mathrm{V}$.

As the anion at the $\mathrm{O} 3$ site is bonded to one $Y$ and two $Z$ cations, the cations occurring in the local arrangements around $\mathrm{O} 1$ should also be involved with the local arrangements around $\mathrm{O} 3$. In the studied samples, the $\mathrm{O} 3$ site is essentially occupied by $(\mathrm{OH})$, thus practically all the $\mathrm{Z}$-cations (e.g., $\mathrm{Al}, \mathrm{Cr}, \mathrm{V}, \mathrm{Mg}$ ) impact on the absorption bands of the infrared and Raman spectra around $\mathrm{O} 3$ because they are part of the general local arrangement $\left[{ }^{\mathrm{Y}}(R)-{ }^{\mathrm{O} 3}(\mathrm{OH}){ }^{\mathrm{Z}}(R+R)\right]$, where $R$ is a generalized cation. Moreover, in accord with bond-valence requirements (Hawthorne 1996; Bosi 2011), the high amounts of $R^{3+}$ at the $Y$ and $Z$ sites may determine the occurrence of $\mathrm{O}^{2-}$ at the $\mathrm{O} 3$ site, with arrangements of the type $\left[{ }^{\mathrm{Y}}\left(R^{3+}\right)-{ }^{\mathrm{O} 3}\left(\mathrm{O}^{2-}\right){ }^{\mathrm{Z}}\left(R^{3+}+R^{3+}\right)\right]$. If these arrangements occur, they will cause a disorder of $(\mathrm{OH})^{1-}$ between the $\mathrm{O} 3$ and $\mathrm{O} 1$ sites via the mechanism ${ }^{\mathrm{O} 3}(\mathrm{OH})^{1-}+{ }^{\mathrm{O} 1}\left(\mathrm{O}^{2-}\right) \leftrightarrow$ ${ }^{\mathrm{O} 3}\left(\mathrm{O}^{2-}\right)+{ }^{\mathrm{O} 1}(\mathrm{OH})^{1-}$. Although it is difficult to quantify ${ }^{\mathrm{O} 3}\left(\mathrm{O}^{2-}\right)$ and ${ }^{\mathrm{O} 1}(\mathrm{OH})^{1-}$ associated with such a disordering mechanism, the spectra of Fig. 1 show peaks at wavenumber $>3650 \mathrm{~cm}^{-}$ ${ }^{1}$ indicative of ${ }^{\mathrm{O} 1}(\mathrm{OH})^{1-}$ (see below) also in samples previously defined as ${ }^{\mathrm{O} 1}(\mathrm{OH})$-free (Table 8). Therefore, it is likely that arrangements of the type $\left[{ }^{\mathrm{O} 1}(\mathrm{OH})^{1-}-{ }^{\mathrm{Y}}\left(R^{3+}\right){ }^{\mathrm{O} 3}\left(\mathrm{O}^{2-}\right)-\right.$ $\left.\mathrm{Z}_{(}\left(R^{3+}+R^{3+}\right)\right]$ may occur, as in sample Tmt6b: the structural formula indicates absence of ${ }^{\mathrm{O} 1}(\mathrm{OH})^{1-}$ (Table 8), whereas the IR spectrum (Fig. 1a) shows the presence of weak bands at 
$\sim 3712-3762 \mathrm{~cm}^{-1}$. The amount of disorder of $(\mathrm{OH})$ should, however, be very small since the peaks at wavenumber $>3650 \mathrm{~cm}^{-1}$ are much weaker than those at wavenumber $<3650$ $\mathrm{cm}^{-1}$ and, in some samples, amounts of ${ }^{\mathrm{O} 1}(\mathrm{OH})$ are already predicted by stoichiometry (Table 8).

\section{Relation between octahedral site population and vibrational peak area intensity}

In line with previous studies (e.g., Gonzalez-Carreño et al. 1988; Bosi et al. 2012b) and the small ${ }^{\mathrm{O}}(\mathrm{OH})^{1-}$ contents observed in the studied samples, it can be anticipated that the weak vibrational bands above $3650 \mathrm{~cm}^{-1}$ are related to the $\mathrm{O} 1$ site and the strong bands below $3650 \mathrm{~cm}^{-1}$ to the $\mathrm{O} 3$ site (Fig. 1).

A strong positive correlation occurs between $\mathrm{Al}_{\text {total }}$ and the peak area intensity (PAI) in the IR (and Raman) spectra at 3565 (and 3556 in Raman) $\mathrm{cm}^{-1}\left(\mathrm{r}^{2}>0.9\right)$ as well as between $\mathrm{Cr}_{\text {total }}$ and PAI at 3519 (and 3520 in Raman) $\mathrm{cm}^{-1}\left(\mathrm{r}^{2}>0.9\right)$, indicating a distinct role of $\mathrm{Al}$ and $\mathrm{Cr}$ for the cause of these two bands. Consequently, the accommodation of cations at the $Y$ and $Z$ sites is expected to be related to PAI via the substitutions (1), (2) and (3), and in fact, high correlations between the amounts of $\mathrm{Mg}$ and $\mathrm{Cr}$ at the $Y$ site and PAI are observed, whereas no reliable correlation was observed with ${ }^{\mathrm{Y}} \mathrm{Al}$. Compared to the Raman spectra, the IR spectra appear to be of better quality and could also be acquired for all the six samples. Consequently, the IR data will be used to evaluate the relation between site population and vibrational peak area intensity. However, it can be noted that the Raman spectra obtained parallel to the c-axis essentially show the same trend as observed by FTIR spectra obtained perpendicular to the c-axis.

Fig. 4a displays the positive correlation between $\mathrm{Mg}$ at the $Y$ site and PAI at 3565 $\mathrm{cm}^{-1}$ from oxy-chromium-dravite via chromo-alumino-povondraite to oxy-dravite, indicating that the occurrence of this band is strongly related to a local arrangement involving $\mathrm{Mg}$ at the $Y$ site. Moreover, the deviation of the slope of the linear regression ( 50) from the ideal value expected for oxy-dravite $(=100)$ can be ascribed to the essentially constant sum of monovalent anions $[\mathrm{F}+(\mathrm{OH})]$ at the $\mathrm{O} 1$ site $(\sim 0.3 \mathrm{apfu})$ which represent the dravite and fluor-dravite components. Consequently, ${ }^{\mathrm{Y}} \mathrm{Mg}$ should be bonded to ${ }^{\mathrm{O} 1} \mathrm{O}^{2-}$ and ${ }^{\mathrm{O} 1}(\mathrm{OH}, \mathrm{F})$ according to the following two cluster proportions: $\left[{ }^{\mathrm{O} 1}\left(\mathrm{O}^{2-}\right)-{ }^{\mathrm{Y}}(\mathrm{Mg})-\right.$ $\left.{ }^{\mathrm{O} 3}(\mathrm{OH})-{ }^{\mathrm{Z}}(R+R)\right]_{0.7}$ and $\left[{ }^{\mathrm{O} 1}(\mathrm{OH}, \mathrm{F})-{ }^{\mathrm{Y}}(\mathrm{Mg})-{ }^{\mathrm{O} 3}(\mathrm{OH})-{ }^{\mathrm{Z}}(R+R)\right]_{0.3}$. The band at $3519 \mathrm{~cm}^{-1}$ 
shows a high positive correlation with $\mathrm{Cr}$ at $Y$ from oxy-dravite to oxy-chromium-dravite (Fig. 4b), indicating that this band is strictly related to a local arrangement involving $\mathrm{Cr}$ at the $Y$ site. As the slope of the linear regression $(\sim 33)$ is in very good agreement with the substitution (3), ${ }^{\mathrm{Y}} \mathrm{Cr}$ should be mainly bonded to ${ }^{\mathrm{O} 1} \mathrm{O}^{2-}$ rather than to ${ }^{\mathrm{O}}(\mathrm{OH}, \mathrm{F})$ according to the cluster: $\left[{ }^{\mathrm{O} 1}\left(\mathrm{O}^{2-}\right)-{ }^{\mathrm{Y}}(\mathrm{Cr})-{ }^{\mathrm{O} 3}(\mathrm{OH})-{ }^{\mathrm{Z}}(R+R)\right]$.

The bands at $3565 \mathrm{~cm}^{-1}$ and $3519 \mathrm{~cm}^{-1}$ can therefore be assumed to be associated with ${ }^{\mathrm{Y}} \mathrm{Mg}$ and ${ }^{\mathrm{Y}} \mathrm{Cr}$ (respectively). However, these absorption bands also show relations with the cations at the $Z$ site, which can be explained by the substitutions (1) and (2). The relation between $\mathrm{Cr}$ at $Z$ and PAI at $3565 \mathrm{~cm}^{-1}$ is displayed in Fig. 5a, indicating that this band first increases from oxy-chromium-dravite to chromo-alumino-povondraite with decreasing ${ }^{\mathrm{Z}} \mathrm{Cr}$ according to the substitution (1), ${ }^{\mathrm{Z}} \mathrm{Al} \rightarrow{ }^{\mathrm{Z}} \mathrm{Cr}$, and then continues to increase towards oxy-dravite but with increasing ${ }^{\mathrm{Z}} \mathrm{Al}$ (and ${ }^{\mathrm{Y}} \mathrm{Mg}$ ) according to the substitution (2): ${ }^{\mathrm{Y}}(2 \mathrm{Al}+\mathrm{Mg})+{ }^{\mathrm{Z}}(\mathrm{Al}) \rightarrow{ }^{\mathrm{Y}}(3 \mathrm{Cr})+{ }^{\mathrm{Z}}(\mathrm{Mg})$. A corresponding explanation can be given for the relation between $\mathrm{Cr}$ at $Z$ and PAI at $3519 \mathrm{~cm}^{-1}$ (Fig. 5b). This band decreases from oxychromium-dravite to chromo-alumino-povondraite with decreasing ${ }^{\mathrm{Z}} \mathrm{Cr}$ according to substitution (1), and then continues to decrease to oxy-dravite but with decreasing ${ }^{\mathrm{Y}} \mathrm{Cr}$ according to substitution (2). The correlation between Al at $Z$ and PAI at $3565 \mathrm{~cm}^{-1}$ (Fig. 5c) can be explained in a similar way. This band increases from oxy-chromium-dravite to chromo-alumino-povondraite with increasing ${ }^{\mathrm{Z}} \mathrm{Al}$ according to substitution (1), and then continues to increase to oxy-dravite with increasing ${ }^{\mathrm{Z}} \mathrm{Al}$ (and ${ }^{\mathrm{Y}} \mathrm{Mg}$ ) according to substitution (2). A corresponding explanation can also be given for the correlation between $\mathrm{Al}$ at $Z$ and PAI at $3519 \mathrm{~cm}^{-1}$ (Fig. 5d). This band decreases from oxy-chromium-dravite to chromo-alumino-povondraite with increasing ${ }^{\mathrm{Z}} \mathrm{Al}$ according to the substitution (1), and then continues to decrease to oxy-dravite but with decreasing ${ }^{\mathrm{Y}} \mathrm{Cr}$ according to substitution (2). The occurrence of a negative correlation between ${ }^{\mathrm{Z}} \mathrm{Mg}$ and the PAI at $3565 \mathrm{~cm}^{-1}$ (Fig. 5e) from oxy-chromium-dravite to oxy-dravite can be explained by the substitution (3), ${ }^{\mathrm{Y}}(2 \mathrm{Al}+$ $\mathrm{Mg})+{ }^{\mathrm{Z}}(5 \mathrm{Al}) \rightarrow{ }^{\mathrm{Y}}(3 \mathrm{Cr})+{ }^{\mathrm{Z}}(4 \mathrm{Cr}+\mathrm{Mg})$, which decrease ${ }^{\mathrm{Z}} \mathrm{Mg}$ and increase ${ }^{\mathrm{Y}} \mathrm{Mg}$. Likewise, the positive correlation between ${ }^{\mathrm{Z}} \mathrm{Mg}$ and the PAI at $3519 \mathrm{~cm}^{-1}$ (Fig. 5f) is linked to ${ }^{\mathrm{Y}}(3 \mathrm{Cr}$ ) $+{ }^{\mathrm{Z}}(4 \mathrm{Cr}+\mathrm{Mg}) \rightarrow{ }^{\mathrm{Y}}(2 \mathrm{Al}+\mathrm{Mg})+{ }^{\mathrm{Z}}(5 \mathrm{Al})$, which increases both ${ }^{\mathrm{Z}} \mathrm{Mg}$ and ${ }^{\mathrm{Y}} \mathrm{Cr}$.

In summary, the band at $3565 \mathrm{~cm}^{-1}$ can be ascribed to the clusters $\left[{ }^{\mathrm{O} 1}\left(\mathrm{O}^{2-}\right)-^{\mathrm{Y}}(\mathrm{Mg})-\right.$ $\left.{ }^{\mathrm{O} 3}(\mathrm{OH})-{ }^{\mathrm{Z}}\left(\mathrm{Al}_{1.7} \mathrm{Mg}_{0.3}\right)\right]_{0.7}$ and $\left[{ }^{\mathrm{O} 1}(\mathrm{OH}, \mathrm{F})-{ }^{\mathrm{Y}}(\mathrm{Mg})-{ }^{\mathrm{O} 3}(\mathrm{OH})-{ }^{\mathrm{Z}}(\mathrm{AlAl})\right]_{0.3}$ which represent the oxy-dravite and (fluor-)dravite components (respectively), whereas the band at $3519 \mathrm{~cm}^{-1}$ 
can be ascribed to $\left[{ }^{\mathrm{O} 1}\left(\mathrm{O}^{2-}\right)-{ }^{\mathrm{Y}}(\mathrm{Cr})-{ }^{\mathrm{O} 3}(\mathrm{OH})-{ }^{\mathrm{Z}}\left(\mathrm{Al}_{1.3} \mathrm{Mg}_{0.7}\right)\right]$ and $\left[{ }^{\mathrm{O} 1}\left(\mathrm{O}^{2-}\right)-{ }^{\mathrm{Y}}(\mathrm{Cr}){ }^{\mathrm{O} 3}(\mathrm{OH})-\right.$ $\mathrm{Z}_{\left.\left(\mathrm{Cr}_{1.3} \mathrm{Mg}_{0.7}\right)\right]}$ which represent the chromo-alumino-povondraite and oxy-chromium-dravite components (respectively).

\section{(OH) band assignment}

Each of the more frequent local arrangements around the two types of $(\mathrm{OH})$ groups, which occupy the two different crystallographic sites $\mathrm{O} 1$ and $\mathrm{O} 3$, is expected to produce an absorption band in the FTIR and Raman spectra. As above mentioned, the $\mathrm{O} 1$ site is surrounded by three $Y$ cations, whereas the $\mathrm{O} 3$ site is surrounded by one $Y$ and two $Z$ cations. In addition, the occupancy of the $X$ site may also affect the absorption band related to O1 (Gonzalez-Carreño et al. 1988).

In our band assignment model, we assume that the frequency of the $(\mathrm{OH})$ stretching absorption bands is inversely related to the sum of charges of cations which are coordinated to the $(\mathrm{OH})$ group (e.g., Martínez-Alonso et al. 2002; Bosi et al. 2012b). In accordance with Gatta et al. (2014), we also assume that the ${ }^{\mathrm{O} 1}(\mathrm{OH})$ group forms a very weak hydrogen bond (bond strength $<0.05$ valence units), whereas the ${ }^{03}(\mathrm{OH})$ group forms a weak hydrogen bond (bond strength $\sim 0.11$ valence units) with the closest $\mathrm{O} 5$ atom $\left({ }^{\mathrm{O} 3} \mathrm{O}-\right.$ $\left.{ }^{03} \mathrm{H} \cdots \mathrm{O} 5\right)$, and that the strength of the hydrogen bond will influence the frequency of the principal (OH)-stretching vibration (e.g., Libowitzky 1999). Based on these criteria, we arrive at an assignment model for the observed main IR and Raman bands to the following stable short-range arrangements:

- band $3519 \mathrm{~cm}^{-1}$ is assigned to $\left.\left[{ }^{\mathrm{Y}} \mathrm{Cr}^{\mathrm{Z}}(\mathrm{Cr}, \mathrm{Al}){ }^{\mathrm{Z}}(\mathrm{Cr}, \mathrm{Al}, \mathrm{Mg})\right)\right]-{ }^{\mathrm{O} 3}(\mathrm{OH})$

- band $3565 \mathrm{~cm}^{-1}$ is assigned to $\left[{ }^{\mathrm{Y}} \mathrm{Mg}^{\mathrm{Z}} \mathrm{Al}{ }^{\mathrm{Z}}(\mathrm{Al}, \mathrm{Mg})\right]-{ }^{\mathrm{O} 3}(\mathrm{OH})$

- weak bands $3712-3762 \mathrm{~cm}^{-1}$ are assigned to ${ }^{\mathrm{Y}}\left[\mathrm{Mg} \mathrm{Mg}\left(\mathrm{Mg}, R^{3+}\right)\right]-{ }^{\mathrm{O} 1}(\mathrm{OH})$ where $R^{3+}$ is a group of trivalent cations at the $Y$ sites.

\section{Concluding remarks}

The fundamental $(\mathrm{OH})$-stretching bands in IR spectra of tourmalines display pronounced pleochroism (anisotropic intensities) with very strong absorption for spectra polarized along 
the c-axis (e.g., Gebert and Zemann 1965) owing to the orientation of the (OH) dipoles, which is approximately parallel to the c-axis direction (e.g., Gatta et al. 2014). This causes severe problems for the identification of absorption bands related to the $\mathrm{O} 3$ site of tourmaline, as it is generally not possible to thin crystals sufficiently to avoid off-scale intensity of these bands. Raman spectra are normally not affected by this problem, but may suffer from fluorescence effects. In this study, we showed that the combination of single crystal FTIR and Raman spectra collected with $\mathbf{E} \perp \mathbf{c}$ and $\mathbf{E} / / \mathbf{c}$ (respectively) may provide a useful characterization of the local $(\mathrm{OH})$ environments around the $\mathrm{O} 3$ site. Very good correlations were found between the obtained PAI at 3519 and $3565 \mathrm{~cm}^{-1}$ derived from short-range information and the site populations derived from long-range information (i.e., SREF and EMPA). For the system oxy-dravite - chromo-alumino-povondraite - oxychromium-dravite, the band at $3519 \mathrm{~cm}^{-1}$ was shown to be associated with ${ }^{\mathrm{Y}} \mathrm{Cr}-\mathrm{O} 3-(\mathrm{Z}+$ $Z$ ), while the band at $3565 \mathrm{~cm}^{-1}$ was shown to be associated with ${ }^{\mathrm{Y}} \mathrm{Mg}-\mathrm{O} 3-(Z+Z)$.

Acknowledgments Chemical analyses were done with the kind assistance of M. Serracino to whom the authors express their gratitude. L. Reznitskii was supported by a grant from the Russian Foundation for Basic Research (project 13-05-00258). We thanks the reviewers D. Henry and J. Cempirek for their useful suggestions that improved the manuscript.

\section{References}

Bosi F (2010) Octahedrally coordinated vacancies in tourmaline: a theoretical approach. Mineral Mag 74:1037-1044

Bosi F (2011) Stereochemical constraints in tourmaline: from a short-range to a long-range structure. Can Mineral 49:17-27

Bosi F (2013) Bond-valence constraints around the O1 site of tourmaline. Mineral Mag 77:343-351.

Bosi F, Lucchesi S (2004) Crystal chemistry of the schorl-dravite series. Eur J Mineral $16: 335-344$. 
Bosi F, Lucchesi S (2007) Crystal chemical relationships in the tourmaline group: Structural constraints on chemical variability. Am Mineral 92:1054-1063

Bosi F, Skogby H (2013) Oxy-dravite, $\mathrm{Na}\left(\mathrm{Al}_{2} \mathrm{Mg}\right)\left(\mathrm{Al}_{5} \mathrm{Mg}\right)\left(\mathrm{Si}_{6} \mathrm{O}_{18}\right)\left(\mathrm{BO}_{3}\right)_{3}(\mathrm{OH})_{3} \mathrm{O}$, a new mineral species of the tourmaline supergroup. Am Mineral 98:1442-1448

Bosi F, Lucchesi S, Reznitskii L (2004) Crystal chemistry of the dravite-chromdravite series. Eur J Mineral 16:345-352

Bosi F, Balić-Žunić T, Surour AA (2010) Crystal structure analysis of four tourmalines from the Cleopatra's Mines (Egypt) and Jabal Zalm (Saudi Arabia), and the role of Al in the tourmaline group. Am Mineral 95:510-518

Bosi F, Reznitskii L, Skogby H (2012a) Oxy-chromium-dravite, $\mathrm{NaCr}_{3}\left(\mathrm{Cr}_{4} \mathrm{Mg}_{2}\right)\left(\mathrm{Si}_{6} \mathrm{O}_{18}\right)\left(\mathrm{BO}_{3}\right)_{3}(\mathrm{OH})_{3} \mathrm{O}$, a new mineral species of the tourmaline supergroup. Am Mineral 97:2024-2030

Bosi F, Skogby H, Agrosì G, Scandale E (2012b) Tsilaisite, $\mathrm{NaMn}_{3} \mathrm{Al}_{6}\left(\mathrm{Si}_{6} \mathrm{O}_{18}\right)\left(\mathrm{BO}_{3}\right)_{3}(\mathrm{OH})_{3} \mathrm{OH}$, a new mineral species of the tourmaline supergroup from Grotta d'Oggi, San Pietro in Campo, island of Elba, Italy. Am Mineral 97:989-994

Bosi F, Skogby H, Hålenius U, Reznitskii L (2013) Crystallographic and spectroscopic characterization of Fe-bearing chromo-alumino-povondraite and its relations with oxy-chromium-dravite and oxy-dravite. Am Mineral 98:1557-1564

Bosi F, Skogby H, Reznitskii L, Hålenius U (2014) Vanadio-oxy-dravite, $\mathrm{NaV}_{3}\left(\mathrm{Al}_{4} \mathrm{Mg}_{2}\right)\left(\mathrm{Si}_{6} \mathrm{O}_{18}\right)\left(\mathrm{BO}_{3}\right)_{3}(\mathrm{OH})_{3} \mathrm{O}$, a new mineral species of the tourmaline supergroup. Am Mineral 99:218-224

Cempírek J, Houzar S, Novák M, Groat LA, Selway JB, Šrein V (2013) Crystal structure and compositional evolution of vanadium-rich oxydravite from graphite quartzite at Bítovánky, Czech Republic. J Geosci 58:149-162.

Castañeda C, Oliveira EF, Gomes N, Soares ACP (2000) Infrared study of OH in tourmaline from the elbaite-schorl series. Am Mineral 85:1503-1507

Ertl A, Hughes JM, Pertlik F, Foit FF Jr, Wright SE, Brandstatter F, Marler B (2002) Polyhedron distortions in tourmaline. Can Mineral 40:153-162

Fantini C, Tavares MC, Krambrock K, Moreira RL, Righi A (2014) Raman and infrared study of hydroxyl sites in natural uvite, fluor-uvite, magnesio-foitite, dravite and elbaite tourmalines. Phys Chem Minerals 41:247-254 
Filip J, Bosi F, Novák M, Skogby H, Tuček J, Čuda J, Wildner M. (2012) Redox processes of iron in the tourmaline structure: example of the high-temperature treatment of $\mathrm{Fe}^{3+}-$ rich schorl. Geochim Cosmochim Acta 86:239-256

Foit FF Jr (1989) Crystal chemistry of alkali-deficient schorl and tourmaline structural relationships. Am Mineral 74:422-431

Gatta GD, Bosi F, McIntyre GJ, Skogby H (2014) First accurate location of two proton sites in tourmaline: A single-crystal neutron diffraction study of oxy-dravite. Mineral Mag 78:681-692

Gebert W, Zemann J (1965) Messung des Ultrarot-Pleochroismus von Mineralen II. Der Pleochroismus der OH-Streckfrequenz in Turmalin. Neues Jahrb Mineral Monatsh $8: 232-235$

Gonzalez-Carreño T, Fernandez M, Sanz J (1988) Infrared and electron microprobe analysis of tourmalines. Phy Chem Minerals 15:452-460

Grice JD, Ercit TS (1993) Ordering of Fe and Mg in the tourmaline crystal structure: the correct formula. Neues Jahrb Mineral Abh 165:245-266

Hawthorne FC (1996) Structural mechanisms for light-element variations in tourmaline. Can Mineral 34:123-132

Hawthorne FC (2002) Bond-valence constraints on the chemical composition of tourmaline. Can Mineral 40:789-797

Hawthorne FC, Henry DJ (1999) Classification of the minerals of the tourmaline group. Eur J Mineral 11:201-215

Henry, D.J. and Dutrow, B.L. (1996) Metamorphic tourmaline and its petrologic applications. In L.M. Anovitz and E.S. Grew, Eds., Boron: Mineralogy, Petrology and Geochemistry, 33, p. 503-557. Reviews in Mineralogy, Mineralogical Society of America, Chantilly, Virginia.

Henry DJ, Novák M, Hawthorne FC, Ertl A, Dutrow B, Uher P, Pezzotta F (2011) Nomenclature of the tourmaline supergroup minerals. Am Mineral 96: 895-913.

Hoang LH, Hien NTM, Chen XB, Minh NV, Yang I-S (2011) Raman spectroscopic study of various types of tourmalines. J Raman Spec 42:1442-1446

Libowitzky E, (1999) Correlation of $\mathrm{O}-\mathrm{H}$ stretching frequencies and $\mathrm{O}-\mathrm{H}^{\cdots} \mathrm{O}$ hydrogen bond lengths in minerals. Monatsh Chemie 130:1047-1059 
Lussier AJ, Hawthorne FC, Aguiar PM, Michaelis VK, Kroeker S (2011) Elbaiteliddicoatite from Black Rapids glacier, Alaska. Period Mineral 80:57-73

Martìnez-Alonso S, Rustad JR, Goetz AFH (2002) Ab initio quantum mechanical modeling of infrared vibrational frequencies of the $\mathrm{OH}$ group in dioctahedral phyllosilicates. Part II: Main physical factors governing the $\mathrm{OH}$ vibrations. Am Mineral 87:12241234

Pouchou JL, Pichoir F (1991) Quantitative analysis of homogeneous or stratified microvolumes applying the model "PAP." In K.F.J. Heinrich and D.E. Newbury, Eds., Electron Probe Quantitation, p. 31-75. Plenum, New York

Reznitskii L, Clark CM, Hawthorne FC, Grice JD, Skogby H, Hålenius U, Bosi F (2014) Chromo-alumino-povondraite, $\mathrm{NaCr}_{3}\left(\mathrm{Al}_{4} \mathrm{Mg}_{2}\right)\left(\mathrm{Si}_{6} \mathrm{O}_{18}\right)\left(\mathrm{BO}_{3}\right)_{3}(\mathrm{OH})_{3} \mathrm{O}$, a new mineral species of the tourmaline supergroup. Am Mineral 99:1767-1773

Sheldrick G M (2013) SHELXL2013. University of Göttingen, Germany

Skogby H, Bosi F, Lazor P (2012) Short-range order in tourmaline: a vibrational spectroscopic approach to elbaite. Phy Chem Minerals 39:811-816

Wright SE, Foley JA, Hughes JM (2000) Optimization of site occupancies in minerals using quadratic programming. Am Mineral 85:524-531 


\section{List of tables}

Table 1. Methodologies used to characterize the six oxy-tourmaline samples used in this study and references.

Table 2. Single-crystal X-ray diffraction data details for oxy-chromium-dravite (T89104) and oxy-dravite (PR108).

Table 3. Fractional atom coordinates and site occupancy for oxy-chromium-dravite (T89104) and oxy-dravite (PR108).

Table 4. Displacement parameters $\left(\AA^{2}\right)$ for oxy-chromium-dravite (T89104) and oxydravite (PR108).

Table 5. Selected bond distances $(\AA)$ for oxy-chromium-dravite (T89104) and oxy-dravite (PR108).

Table 6. Chemical composition for oxy-chromium-dravite (T89104) and oxy-dravite (PR108).

Table 7. Cation site populations (apfu), mean atomic numbers and mean bond lengths ( $(\AA)$ for oxy-chromium-dravite (T89104) and oxy-dravite (PR108).

Table 8. Structural formulae of six oxy-tourmalines used in this study.

Table 9. Sample thicknesses and relative peak area intensities for infrared $(\mathbf{E} \perp \mathbf{c})$ and Raman (E // c) bands.

\section{List of figures and figure captions}

Figure 1. FTIR spectra polarized parallel (a) and perpendicular (b) to the c-axis direction. From top to bottom: sample PR108, PR107, Tm1p43e, PR85v, Tmt6b and T89104. Dotted spectra indicate the two fitted bands for the T89104 spectrum. Spectra are vertically offset for clarity.

Figure 2. Raman spectra polarized parallel to the c-axis direction. From top to bottom: sample PR107, Tm1p43e, PR85v and T89104. Spectra are vertically offset for clarity. 
Figure 3. Ternary diagram of the $\mathrm{V}_{\text {total }}-\mathrm{Cr}_{\text {total }}-\mathrm{Al}_{\text {total }}$ subsystem for oxy-tourmaline $\mathrm{Na}^{\mathrm{Y}}\left(R^{3+}\right)_{3}{ }^{\mathrm{Z}}\left(R_{4}{ }^{3+} \mathrm{Mg}_{2}\right) \mathrm{Si}_{6} \mathrm{O}_{18}\left(\mathrm{BO}_{3}\right)_{3}(\mathrm{OH})_{3} \mathrm{O}$. The solid black circles represent the samples used in this study. $\mathrm{Cr}_{5} \mathrm{Al}_{2}$ and $\mathrm{Cr}_{1.5} \mathrm{Al}_{5.5}$ indicate the borderlines between oxy-chromium-dravite and chromo-alumino-povondraite and between oxy-dravite and chromo-alumino-povondraite, respectively.

Figure 4. (a) Relative peak area intensity (PAI) for the $3565 \mathrm{~cm}^{-1}$ band versus $\mathrm{Mg}$ at $Y$. Dashed lines indicate expected correlation for ideal solid-solution between oxychromium-dravite-oxy-dravite and oxy-chromium-dravite-(fluor-)dravite. (b) PAI for the $3519 \mathrm{~cm}^{-1}$ band versus $\mathrm{Cr}$ at $Y$. Dashed line indicates expected correlation for ideal solid-solution between oxy-dravite and oxy-chromiumdravite. Solid lines are linear regressions for the experimental data fitted through the origin.

Figure 5. Plots of peak area distribution for the $3565 \mathrm{~cm}^{-1}$ and $3519 \mathrm{~cm}^{-1}$ bands versus cation occupancy at the $Z$ site. Solid lines are guide for the eye, dashed lines represent a linear distribution between the end-members. (a) PAI for the 3519 $\mathrm{cm}^{-1}$ band versus $\mathrm{Cr}$ at $Z$. (b) PAI for the $3519 \mathrm{~cm}^{-1}$ band versus $\mathrm{Cr}$ at $Z$. (c) PAI for the $3565 \mathrm{~cm}^{-1}$ band versus $\mathrm{Al}$ at $Z$. (d) PAI for $3519 \mathrm{~cm}^{-1}$ band versus $\mathrm{Al}$ at $Z$. (e) PAI for the $3565 \mathrm{~cm}^{-1}$ band versus $\mathrm{Mg}$ at $Z$. (f) PAI for the 3519 $\mathrm{cm}^{-1}$ band versus $\mathrm{Mg}$ at $Z$. See text for further explanation. 


\title{
Atomic arrangements around the $\mathrm{O3}$ site in Al- and Cr-rich oxy- tourmalines: a combined EMP, SREF, FTIR and Raman study
}

\author{
Ferdinando Bosi ${ }^{1,2}$, Henrik Skogby ${ }^{2}$, Peter Lazor ${ }^{3}$ and Leonid Reznitskii ${ }^{4}$
}

${ }^{1}$ Dipartimento di Scienze della Terra, Sapienza Università di Roma, Piazzale Aldo Moro, 5, I-00185 Rome, Italy

${ }^{2}$ Department of Geosciences, Swedish Museum of Natural History, Box 50007, SE-10405

Stockholm, Sweden

${ }^{3}$ Department of Earth Sciences, Uppsala University, SE-752 36 Uppsala, Sweden

${ }^{4}$ Institute of the Earth's Crust, Siberian Branch, Russian Academy of Science, Lermontova str., 128, 664033 Irkutsk, Russia

Corresponding author:

Ferdinando Bosi, e-mail: ferdinando.bosi@uniroma1.it, tel: +39 0649914901, fax: +39 064454729

\begin{abstract}
An experimental study on oxy-tourmalines belonging to the system oxy-dravite chromo-alumino-povondraite - oxy-chromium-dravite from the Sludyanka crystalline complex (Southern Baikal region, Russia) was carried out using electron microprobe analysis (EMPA), structural refinement (SREF), infrared (IR) and Raman single crystal spectroscopy in order to explore the characteristic vibrational bands in the principal $(\mathrm{OH})$ stretching frequency and their relations to the $\mathrm{O} 3$ anion site of the tourmaline structure. The studied oxy-tourmalines are characterized by the substitution $\mathrm{Al} \leftrightarrow \mathrm{Cr}$ which is accompanied by redistribution of $\mathrm{Mg}$ over the $Y$ and $Z$ sites. The occurrence of strong correlations between relative peak area intensities for two bands at 3565 and $3519 \mathrm{~cm}^{-1}$ and
\end{abstract}


cation site populations derived from SREF and EMP data allowed to ascribe the band at $3565 \mathrm{~cm}^{-1}$ to the cluster $\left[{ }^{\mathrm{Y}} \mathrm{Mg}{ }^{\mathrm{Z}} \mathrm{Al}{ }^{\mathrm{Z}}(\mathrm{Al}, \mathrm{Mg})\right]-\mathrm{O} 3$ and the band at $3519 \mathrm{~cm}^{-1}$ to the cluster $\left.\left[{ }^{\mathrm{Y}} \mathrm{Cr}^{\mathrm{Z}}(\mathrm{Cr}, \mathrm{Al}){ }^{\mathrm{Z}}(\mathrm{Cr}, \mathrm{Al}, \mathrm{Mg})\right)\right]-\mathrm{O} 3$.

Moreover, this study showed that the combination of polarized IR and Raman spectra collected with the electric vector $\mathbf{E} \perp \mathbf{c}$ and $\mathbf{E} / / \mathbf{c}$ (respectively) may provide a useful characterization of the local $(\mathrm{OH})$ environments around the $\mathrm{O} 3$ site of the tourmaline structure.

Keywords Tourmaline, Electron microprobe, Crystal structure refinement, Infrared spectroscopy, Raman spectroscopy, Short-range arrangement

\section{Introduction}

Tourmalines are complex borosilicates and their crystal structure and crystal chemistry have been extensively studied (e.g., Foit 1989; Ertl et al. 2002; Hawthorne and Henry 1999; Bosi et al. 2010; Lussier et al. 2011; Filip et al. 2012). In accordance with Henry et al. (2011), the general formula of tourmaline may be written as: $X Y_{3} Z_{6} T_{6} \mathrm{O}_{18}\left(B \mathrm{O}_{3}\right)_{3} V_{3} W,{ }^{[9]} X=$ $\mathrm{Na}^{+}, \mathrm{K}^{+}, \mathrm{Ca}^{2+}, \square$ (=vacancy); ${ }^{[6]} Y=\mathrm{Al}^{3+}, \mathrm{Fe}^{3+}, \mathrm{Cr}^{3+}, \mathrm{V}^{3+}, \mathrm{Mg}^{2+}, \mathrm{Fe}^{2+}, \mathrm{Mn}^{2+}, \mathrm{Li}^{+} ;{ }^{[6]} \mathrm{Z}=\mathrm{Al}^{3+}$, $\mathrm{Fe}^{3+}, \mathrm{Cr}^{3+}, \mathrm{V}^{3+}, \mathrm{Mg}^{2+}, \mathrm{Fe}^{2+} ;{ }^{[4]} T=\mathrm{Si}^{4+}, \mathrm{Al}^{3+}, \mathrm{B}^{3+} ;{ }^{[3]} B=\mathrm{B}^{3+} ; V\left(\equiv{ }^{[3]} \mathrm{O} 3\right)=\mathrm{OH}^{1-}, \mathrm{O}^{2-} ; W(\equiv$ $\left.{ }^{[3]} \mathrm{O} 1\right)=\mathrm{OH}^{1-}, \mathrm{F}^{1-}, \mathrm{O}^{2-}$.

Vibrational transitions in the $(\mathrm{OH})$-stretching region has been presented for tourmaline in a number of studies (e.g., Gonzalez-Carreño et al. 1988; Castañeda et al. 2000; Hoang et al. 2011; Fantini et al. 2014). For elbaite, Skogby et al. (2012) presented a unifying assignment model for observed $(\mathrm{OH})$ stretching bands using a combination of long-range information (based on diffraction techniques) and short-range information (based on spectroscopic techniques).

In this paper, we use a similar approach to explore the infrared (IR) and Raman spectra in the wavenumber region $3000-4000 \mathrm{~cm}^{-1}$ of six single crystals of oxy-tourmalines 
belonging to the solid solution system oxy-dravite - chromo-alumino-povondraite - oxychromium-dravite, and present a model to link the vibrational bands to stable short-range arrangements supported by bond-valence constraints.

\section{Samples}

The samples used in this study (T89104, Tmt6b, PR85v, Tm1p43e, PR107 and PR108) are emerald green and comes from metaquartzites in the Pereval marble quarry, Sludyanka crystalline complex, Southern Baikal region, Russia. At this locality (see Bosi et al. 2012a for a more detailed description), Cr-V-bearing metamorphic rocks are associated with $\mathrm{Cr}$ V-bearing diopside and tremolite, escolaite, uvarovite, chromite, V-bearing titanite, pyrite, barite and calcite together with euhedral and subhedral crystals of tourmaline. The hostrock consists of a lens (10-15 cm thickness) of greenish-grey medium-grained quartzite within the marbles of the Pereval quarry. The crystals are euhedral, reaching up to $0.3 \mathrm{~mm}$ in length, and are often chemically zoned, but homogeneous crystals also occur.

Four of the six studied oxy-tourmalines (samples Tmt6b, PR85v, Tm1p43e and PR107) have previously been structurally and chemically characterized by means of X-ray single-crystal diffraction, electron microprobe analysis and Mössbauer spectroscopy. Moreover, samples PR85v and PR107 were also characterized by means of IR and optical absorption spectroscopy (Bosi et al. 2004; Bosi et al. 2013; Reznitskii et al. 2014). The obtained structural and chemical information revealed a chemical composition corresponding to the chromo-alumino-povondraite species with a variation predominantly in the $\mathrm{Al}$ and $\mathrm{Cr}$ contents. In order to cover the major compositional range characterized by the $\mathrm{Cr}$ for $\mathrm{Al}$ substitution, an oxy-dravite sample (PR108) and an oxy-chromium-dravite (T89104) was also structurally and chemically characterized. These samples were also characterized by IR and Raman single crystal spectroscopy (for details, see Table 1).

\section{Experimental methods}

Single-crystal structural refinement 
Two representative crystals of oxy-dravite (sample PR108) and oxy-chromium-dravite (sample T89104) were selected for X-ray diffraction measurements on a Bruker KAPPA APEX-II single-crystal diffractometer, at Sapienza University of Rome (Earth Sciences Department), equipped with a CCD area detector $\left(6.2 \times 6.2 \mathrm{~cm}^{2}\right.$ active detection area, 512 $\times 512$ pixels) and a graphite crystal monochromator, using MoKa radiation from a finefocus sealed X-ray tube. The sample-to-detector distance was $4 \mathrm{~cm}$. A total of 3265 (for PR108) and 1469 (for T89104) exposures (step $=0.2^{\circ}$, time/step $=20 \mathrm{~s}$ ) covering the full reciprocal sphere with a redundancy of about 10 (for PR108) and 6 (for T89104). Final unit-cell parameters were refined with the Bruker AXS SAINT program using reflections with $I>10 \sigma(I)$ in the range $5^{\circ}<2 \theta<70^{\circ}$. The intensity data were processed and corrected for Lorentz, polarization, and background effects with the APEX2 software program of Bruker AXS. The data were corrected for absorption using the multi-scan method (SADABS). The absorption correction led to a significant improvement in $R_{\text {int }}$. No violations of $R 3 m$ symmetry were noted.

Structural refinement was done with the SHELXL-2013 program (Sheldrick 2013). Starting coordinates were taken from Bosi et al. (2014). Variable parameters were: scale factor, extinction coefficient, atom coordinates, site scattering values and atom displacement factors. In detail, the $X$ site was modeled by using the Na scattering factor; the $Y$ site was modeled considering the presence of $\mathrm{Cr}$ and $\mathrm{Mg}$; the occupancy of the $Z$ site was modeled considering $\mathrm{Al}$ for sample PR108, and $\mathrm{Cr}$ and $\mathrm{Mg}$ for sample T89104. The $T$ and $B$ sites were modeled, respectively, with $\mathrm{Si}$ and $\mathrm{B}$ scattering factors and with a fixed occupancy of 1 , because refinement with unconstrained occupancies showed no significant deviations from this value. Three full-matrix refinement cycles with isotropic displacement parameters for all atoms were followed by anisotropic cycles until convergence was attained. No significant correlations over a value of 0.7 between the parameters were observed at the end of refinement. Table 2 lists crystal data, data-collection information and refinement details; Table 3 gives the fractional atom coordinates and site occupancies; Table 4 gives the displacement parameters; Table 5 gives selected bond distances.

\section{Electron microprobe analysis}


Electron-microprobe analyses of the crystals used for X-ray diffraction refinement were obtained by wavelength-dispersive spectrometry (WDS mode) with a Cameca SX50 instrument at the "Istituto di Geologia Ambientale e Geoingegneria (Rome, Italy), CNR", operating at an accelerating potential of $15 \mathrm{kV}$ and a sample current of $15 \mathrm{nA}, 10 \mu \mathrm{m}$ beam diameter. Minerals and synthetic compounds were used as standards: wollastonite ( $\mathrm{Si}, \mathrm{Ca}$ ), magnetite $(\mathrm{Fe})$, rutile $(\mathrm{Ti})$, corundum $(\mathrm{Al})$, vanadinite $(\mathrm{V})$ fluorphlogopite $(\mathrm{F})$, periclase $(\mathrm{Mg})$, jadeite $(\mathrm{Na})$, K-feldspar $(\mathrm{K})$, sphalerite $(\mathrm{Zn})$, metallic $\mathrm{Cr}, \mathrm{Mn}$ and $\mathrm{Cu}$. The overlap corrections and the PAP routine were applied (Pouchou and Pichoir 1991). The results (Table 6) represent mean values of 10 spot analyses. In accord with the very low concentration of $\mathrm{Li}$ in dravitic samples (e.g., Henry et al. 2011) and the crystallization environment of the studied sample (i.e., Cr-bearing metaquartzites), the $\mathrm{Li}_{2} \mathrm{O}$ content was assumed to be insignificant. The elements $\mathrm{Mn}, \mathrm{Fe}, \mathrm{Cu}$, and $\mathrm{Zn}$ were below the detection limits $(0.03 \mathrm{wt} \%)$ in the studied sample.

\section{Single crystal infrared spectroscopy}

Representative crystals of the four tourmaline samples that had not previously been studied were measured by Fourier transform infrared (FTIR) spectroscopy to characterize their $(\mathrm{OH})$ vibrational absorption bands. The spectrometer system consisted of a Bruker Equinox 55 spectrometer in conjunction with a Biorad infrared microscope, using a halogen lamp source, a $\mathrm{CaF}_{2}$ beam-splitter, a wire-grid polarizer (KRS-5) and an MCT detector. The crystals were oriented by morphology and optical microscopy, mounted on glass plates in thermoplastic resin and polished on two parallel sides, including the c-axis direction. Polarized absorption spectra were then acquired with a resolution of $4 \mathrm{~cm}^{-1}$ in the wavenumber range $2000-5000 \mathrm{~cm}^{-1}$ parallel and perpendicular to the crystallographic c-axis direction, using rectangular measurement areas of ca. $50 \times 50 \mu \mathrm{m}$ on the $26-50 \mu \mathrm{m}$ thick crystals. Sample Tmt6b that was available in slightly larger crystal size was mounted on a $100 \mu \mathrm{m}$ pin-hole aperture and was measured in the sample compartment of the spectrometer system using the same set-up, except for an InSb detector. As typically observed for tourmaline samples, the main $(\mathrm{OH})$ absorption bands polarized parallel the caxis direction were exceedingly intense, and it was not possible to thin the samples sufficiently to avoid off-scale absorption intensity for the strongest bands. Spectra obtained 
perpendicular to c-axis direction were analyzed by band-fitting using the Jandel PeakFit 4.12 software.

\section{Single crystal Raman spectroscopy}

Raman spectra were recorded on five representative single crystals using a spectroscopic system built at the Department of Earth Sciences, Uppsala University. The key system components include a high-throughput, single stage imaging spectrometer (HoloSpec f/1.8i, Kaiser Optical Systems, Inc.) equipped with a holographic transmission grating and a thermoelectrically cooled $\left(-60^{\circ} \mathrm{C}\right) \mathrm{CCD}$ detector (Newton, Andor Technology, $1600 \times 400$ pixels), a diode-pumped laser (Samba by Cobolt AB, $532.42 \mathrm{~nm}, 150 \mathrm{~mW} \mathrm{CW}$ ), and an optical imaging system (magnification $20 \times$, spatial resolution $\sim 1 \mu \mathrm{m}$ ). Two notch filters (Ondax Inc.) blocked the Rayleigh line. Polarized Raman spectra in parallel and perpendicular $\mathbf{c}$-axis directions $\left(\mathrm{n}_{\varepsilon}\right.$ and $\left.\mathrm{n}_{\omega}\right)$ were collected in the back-scattering geometry at a resolution and accuracy of about $2 \mathrm{~cm}^{-1}$ and $1.5 \mathrm{~cm}^{-1}$, respectively. Typical acquisition time varied between 1 and 4 minutes, applying $15 \mathrm{~mW}$ of the laser power on a doublypolished parallel-plate oriented single crystal, roughly $0.5 \mathrm{~mm}$ thick.

\section{Results}

\section{Determination of atomic proportions}

In agreement with the structural-refinement results, the boron content was assumed to be stoichiometric in samples PR108 and T89104 $\left(\mathrm{B}^{3+}=3.00 \mathrm{apfu}\right)$. Both the site-scattering results and the bond lengths of $B$ and $T$ are consistent with the $B$ site fully occupied by boron and no amount of $\mathrm{B}^{3+}$ at the $T$ site (e.g., Hawthorne 1996; Bosi and Lucchesi 2007). The $(\mathrm{OH})$ content can then be calculated by charge balance with the assumption $T+Y+Z$ $=15.00$. The atomic proportions were calculated on this assumption (Table 6). The excellent match between the number of electrons per formula unit (epfu) derived from chemical and structural analysis supports this procedure, respectively: 240.6 and 239.9 epfu for sample PR108, 279.3 and 279.5 epfu for sample T89104. 


\section{Site populations}

The anion site populations in the studied sample follow the general preference suggested for tourmaline (e.g., Grice and Ercit 1993; Henry et al. 2011): the O3 site (V position in the general formula) is occupied by $(\mathrm{OH})$, and the $\mathrm{O} 1$ site (W position in the general formula) is occupied by $\mathrm{O}^{2-},(\mathrm{OH})^{1-}$ and $\mathrm{F}^{1-}$. The cation distribution at the $T, Y$ and $Z$ sites was optimized by using a quadratic program to minimize the residuals between calculated and observed data (based on the chemical and structural analysis). Site-scattering values, octahedral and tetrahedral mean bond-distances (i.e., $\langle Y-\mathrm{O}\rangle,\langle Z-\mathrm{O}\rangle$ and $\langle T-\mathrm{O}\rangle$ ) were calculated as the linear contribution of each cation multiplied by its ideal bond-distance. More details about the ideal distances as well as the optimization procedure may be found in Bosi et al. (2004) and Bosi and Lucchesi (2004; 2007). The robustness of this approach was confirmed by another optimization procedure (Wright et al. 2000), which led to very similar cation distributions (Table 7). The final structural formulae for samples PR108 and T89104 are reported in Table 8 along with those of the previously studied samples Tmt6b, PR85v, Tm1p43e, and PR107 for comparison reasons. In accordance with the classification of Henry et al. (2011) and the findings of Bosi and Skogby (2013) and Bosi et al. (2012a), samples PR108 and T89104 can be classified, respectively, as oxy-dravite and oxychromium-dravite.

\section{Infrared and Raman spectra}

The IR spectra obtained parallel to the c-axis direction of the tourmaline samples are characterized by a strong absorption feature in the $3450-3600 \mathrm{~cm}^{-1}$ range (Fig. 1a) which is truncated due to exceedingly strong absorption, in line with previous studies (e.g., Bosi et al. 2012b, Skogby et al. 2012). Weak bands occur in the $3700-3800 \mathrm{~cm}^{-1}$ region, and are also polarized in the c-axis direction. Although a slight shift in position of the main absorption feature is apparent, any possible fine structures are obscured by the off-scale intensity recorded along the c-axis. However, spectra polarized perpendicular to the $\mathbf{c}$-axis are much less intense and reveal two partly overlapping bands with systematic variation of their absorption intensities (Fig. 1b). This trend is associated with sample composition, 
where the band at higher wavenumbers increases with decreasing $\mathrm{Cr}$ content. In order to characterize and quantify these intensity shifts, the spectra were fitted with a model using two bands with fixed positions (3519 and $3565 \mathrm{~cm}^{-1}$ ), but varying absorption areas. The band positions were initially obtained by an unconstrained fit of spectra of the most Al-rich sample (PR108) and the most Cr-rich sample (T89104), which are both dominated by one of these bands. The obtained absorption area distributions for the two bands are listed in Table 9.

For the used excitation wavelength, Raman spectra in the $(\mathrm{OH})$-region are characterized by a strong red fluorescence decreasing the signal-to-noise-ratio. This precluded spectral acquisitions for sample with the highest Al-content (PR108) for which the effect was the most pronounced. Raman spectra obtained for electric field (E) direction parallel to the $\mathbf{c}$-axis $(\mathbf{E} / / \mathbf{c})$ are shown in Fig. 2. The overall appearance of spectra as well as their evolution upon varying Al-Cr content resembles that of infrared absorption for the perpendicular configuration $(\mathbf{E} \perp \mathbf{c}$ ) when the above-described two-band fitting model is applied. Positions of bands of the most Cr-rich sample (T89104) were used for all compositions when fitting the Raman spectra. The low quality of the spectrum for the Alrich sample PR107 (Fig. 2) translated into a larger fitting uncertainty. The obtained absorption area distributions for the two bands are listed in Table 9. A somewhat lower value of position of the $3556 \mathrm{~cm}^{-1}$ Raman band, as compared to the corresponding $3565 \mathrm{~cm}^{-}$

${ }^{1}$ IR band, originates likely from comparing the spectra of different polarizations, parallel Raman $(\mathbf{E} / / \mathbf{c})$ versus perpendicular IR $(\mathbf{E} \perp \mathbf{c})$, and from the fitting uncertainties. No Raman bands in the $(\mathrm{OH})$-region were observed for the configuration $\mathbf{E} \perp \mathbf{c}$.

\section{Discussion}

\section{Crystal chemistry}

The six samples used for this study can be referred to the following ideal formulae:

- oxy-chromium-dravite, $\mathrm{Na}^{\mathrm{Y}} \mathrm{Cr}_{3}{ }^{\mathrm{Z}}\left(\mathrm{Cr}_{4} \mathrm{Mg}_{2}\right)\left(\mathrm{Si}_{6} \mathrm{O}_{18}\right)\left(\mathrm{BO}_{3}\right)_{3}(\mathrm{OH})_{3} \mathrm{O}$;

- chromo-alumino-povondraite, $\mathrm{Na}^{\mathrm{Y}} \mathrm{Cr}_{3}{ }^{\mathrm{Z}}\left(\mathrm{Al}_{4} \mathrm{Mg}_{2}\right)\left(\mathrm{Si}_{6} \mathrm{O}_{18}\right)\left(\mathrm{BO}_{3}\right)_{3}(\mathrm{OH})_{3} \mathrm{O}$;

- oxy-dravite, $\mathrm{Na}^{\mathrm{Y}}\left(\mathrm{Al}_{2} \mathrm{Mg}\right)^{\mathrm{Z}}\left(\mathrm{Al}_{5} \mathrm{Mg}\right)\left(\mathrm{Si}_{6} \mathrm{O}_{18}\right)\left(\mathrm{BO}_{3}\right)_{3}(\mathrm{OH})_{3} \mathrm{O}$. 
They all have the $X$ site dominated by $\mathrm{Na}(0.68-0.98 \mathrm{apfu})$ with minor amount of $\mathrm{Ca}$, vacancies and $\mathrm{K}$. The $T$ site is dominated by $\mathrm{Si}$ (5.95-5.99 apfu) along with very minor amounts of $\mathrm{Al}$. The $\mathrm{O} 1$ site is dominated by $\mathrm{O}^{2-}$ ( 0.7 apfu), followed by $\mathrm{F}$ (0.1-0.3 apfu) and then by $(\mathrm{OH})$ (up to $0.3 \mathrm{apfu}$ ). The main compositional variation is characterized by the substitution of $\mathrm{Al}$ for $\mathrm{Cr}^{3+}$ at both the $Y$ and $Z$ sites (Fig. 3). In detail, moving from oxychromium-dravite to chromo-alumino-povondraite and further to oxy-dravite, ${ }^{\mathrm{Y}} \mathrm{Al}$ increases from zero to 0.65 apfu and ${ }^{\mathrm{Z}} \mathrm{Al}$ from 1.80 apfu to 4.33, whereas ${ }^{\mathrm{Y}} \mathrm{Cr}$ decreases from 2.55 to 0.63 apfu and ${ }^{\mathrm{Z}} \mathrm{Cr}$ from 2.23 to 0.33 apfu. Minor amounts of $\mathrm{V}^{3+}(<0.3$ apfu) are also present, alternatively at the $Y$ and $Z$ site. Minor amounts of $\mathrm{Fe}^{3+}(\sim 0.3 \mathrm{apfu})$ are present at the $Z$ site only for sample PR107. The presence of $\mathrm{Mg}$ increases from 0.27 to 1.33 apfu at $Y$, whereas it decreases from 1.96 apfu to 1.34 apfu at $Z$ according to an order-disorder reaction between $R^{3+}$-cations and $\mathrm{Mg}$ at the $Y$ and $Z$ sites (see below). With respect to the ideal formulae, the observed octahedral site populations can chiefly be described by the ideal substitutions that follow:

oxy-chromium-dravite $\leftrightarrow$ chromo-alumino-povondraite

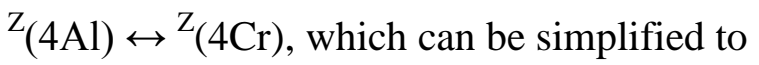

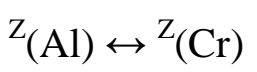

chromo-alumino-povondraite $\leftrightarrow$ oxy-dravite

$$
\begin{aligned}
& \mathrm{Y}_{(3 \mathrm{Cr})}+{ }^{\mathrm{Z}}(4 \mathrm{Al}+\mathrm{Mg}) \leftrightarrow{ }^{\mathrm{Y}}(2 \mathrm{Al}+\mathrm{Mg})+{ }^{\mathrm{Z}}(5 \mathrm{Al}) \text {, which can be simplified to } \\
& { }^{\mathrm{Y}}(3 \mathrm{Cr})+{ }^{\mathrm{Z}}(\mathrm{Mg}) \leftrightarrow{ }^{\mathrm{Y}}(2 \mathrm{Al}+\mathrm{Mg})+{ }^{\mathrm{Z}}(\mathrm{Al})
\end{aligned}
$$

The substitution of $\mathrm{Al}$ for $\mathrm{Cr}$ is accompanied by redistribution of $\mathrm{Mg}$ over the $Y$ and $Z$ sites, which can be summarized by the substitutions occurring along the oxy-chromium-dravite oxy-dravite join:

$$
\begin{aligned}
& { }^{\mathrm{Y}}(3 \mathrm{Cr})+{ }^{\mathrm{Z}}(4 \mathrm{Cr}+2 \mathrm{Mg}) \leftrightarrow{ }^{\mathrm{Y}}(2 \mathrm{Al}+\mathrm{Mg})+{ }^{\mathrm{Z}}(5 \mathrm{Al}+\mathrm{Mg}) \text {, which can be simplified to } \\
& { }^{\mathrm{Y}}(3 \mathrm{Cr})+{ }^{\mathrm{Z}}(4 \mathrm{Cr}+\mathrm{Mg}) \leftrightarrow{ }^{\mathrm{Y}}(2 \mathrm{Al}+\mathrm{Mg})+{ }^{\mathrm{Z}}(5 \mathrm{Al})
\end{aligned}
$$

\section{Short-range arrangements around $\mathrm{Ol}$ and $\mathrm{O} 3$}

Short-range bond-valence requirements around the $\mathrm{O} 1$ site in of tourmaline (Hawthorne 1996, 2002; Bosi 2010, 2011, 2013) invoke the occurrence of the following possible and stable short-range arrangements for the studied samples:

$$
{ }^{\mathrm{Y}}(\mathrm{Mg}+\mathrm{Mg}+\mathrm{Mg})-{ }^{\mathrm{O} 1}(\mathrm{OH}, \mathrm{F}) \text {, }
$$




$$
\begin{aligned}
& \mathrm{Y}\left(\mathrm{Mg}+\mathrm{Mg}+R^{3+}\right)-{ }^{\mathrm{O} 1}(\mathrm{OH}, \mathrm{F}), \\
& \mathrm{Y}\left(\mathrm{Mg}+R^{3+}+R^{3+}\right)-{ }^{\mathrm{O} 1}\left(\mathrm{O}^{2-}\right), \\
& \mathrm{Y}\left(R^{3+}+R^{3+}+R^{3+}\right)-^{\mathrm{O} 1}\left(\mathrm{O}^{2-}\right)
\end{aligned}
$$

where $(\mathrm{OH}, \mathrm{F})$ correspond to two different $\mathrm{O} 1$-site arrangements and $R^{3+}=\mathrm{Al}, \mathrm{Cr}$ and $\mathrm{V}$.

As the anion at the $\mathrm{O} 3$ site is bonded to one $Y$ and two $Z$ cations, the cations occurring in the local arrangements around $\mathrm{O} 1$ should also be involved with the local arrangements around $\mathrm{O} 3$. In the studied sample, the $\mathrm{O} 3$ site is practically fully occupied by $(\mathrm{OH})$, thus all the Z-cations (e.g., $\mathrm{Al}, \mathrm{Cr}, \mathrm{V}, \mathrm{Mg}$ ) impact on the absorption bands of the infrared and Raman spectra around $\mathrm{O} 3$ because they are part of the general local arrangement $\left[{ }^{\mathrm{Y}}(R)-{ }^{\mathrm{O} 3}(\mathrm{OH})-{ }^{\mathrm{Z}}(R+R)\right]$, where $R$ is a generic cation.

\section{Relation between octahedral site population and vibrational peak area intensity}

In line with previous studies (e.g., Gonzalez-Carreño et al. 1988; Bosi et al. 2012b) and the very small ${ }^{\mathrm{O}}(\mathrm{OH})$ contents observed in the structural formulae, it can be anticipated that the weak vibrational bands above $3650 \mathrm{~cm}^{-1}$ are related to the $\mathrm{O} 1$ site and the strong bands below $3650 \mathrm{~cm}^{-1}$ to the $\mathrm{O} 3$ site (Fig. 1).

A strong positive correlation occurs between $\mathrm{Al}_{\text {total }}$ and the peak area intensity (PAI) in the IR (and Raman) spectra at 3565 (and 3556 in Raman) $\mathrm{cm}^{-1}\left(\mathrm{r}^{2}>0.9\right)$ as well as between $\mathrm{Cr}_{\text {total }}$ and PAI at 3519 (and 3520 in Raman) $\mathrm{cm}^{-1}\left(\mathrm{r}^{2}>0.9\right)$, indicating a distinct role of $\mathrm{Al}$ and $\mathrm{Cr}$ for the cause of these two bands. Consequently, the accommodation of cations at the $Y$ and $Z$ sites is expected to be related to PAI via the substitutions (1), (2) and (3), and in fact, high correlations between the amounts of $\mathrm{Mg}$ and $\mathrm{Cr}$ at the $Y$ site and PAI are observed, whereas no relevant correlation was observed with ${ }^{\mathrm{Y}} \mathrm{Al}$. With respect to the Raman spectra, the IR spectra appear to be of better quality and could also be acquired for all the six samples. Consequently, we will use the IR data to evaluate the relation between site population and vibrational peak area intensity. However, it can be noted that the Raman spectra obtained parallel to the c-axis essentially show the same trend as observed by FTIR spectra obtained perpendicular to the c-axis.

Fig. 4a displays the positive correlation between and $\mathrm{Mg}$ at the $Y$ site and PAI at $3565 \mathrm{~cm}^{-1}$ from oxy-chromium-dravite via chromo-alumino-povondraite to oxy-dravite, indicating that the occurrence of this band is strongly related to a local arrangement 
involving $\mathrm{Mg}$ at the $Y$ site. Moreover, the deviation of the angular coefficient of the linear regression $(\sim 50)$ from the ideal value expected for oxy-dravite $(=100)$ can be ascribed to the practically constant sum of monovalent anions $[\mathrm{F}+(\mathrm{OH})]$ at the $\mathrm{O} 1$ site $(\sim 0.3 \mathrm{apfu})$ which represent the dravite and fluor-dravite components. Consequently, ${ }^{\mathrm{Y}} \mathrm{Mg}$ should be bonded to ${ }^{\mathrm{O} 1} \mathrm{O}^{2-}$ and ${ }^{\mathrm{O} 1}(\mathrm{OH}, \mathrm{F})$ according to the following two cluster proportions: $\left[{ }^{\mathrm{O}}\left(\mathrm{O}^{2-}\right)-\right.$ $\left.{ }^{\mathrm{Y}}(\mathrm{Mg})-{ }^{\mathrm{O} 3}(\mathrm{OH})-{ }^{\mathrm{Z}}(R+R)\right]_{0.7}$ and $\left[{ }^{\mathrm{O} 1}(\mathrm{OH}, \mathrm{F})-{ }^{\mathrm{Y}}(\mathrm{Mg})-{ }^{\mathrm{O} 3}(\mathrm{OH})-{ }^{\mathrm{Z}}(R+R)\right]_{0.3}$. The band at 3519 $\mathrm{cm}^{-1}$ shows a high positive correlation with $\mathrm{Cr}$ at $Y$ from oxy-dravite to oxy-chromiumdravite (Fig. 4b), indicating that this band is strictly related to a local arrangement involving $\mathrm{Cr}$ at the $Y$ site. As the angular coefficient of the linear regression $(\sim 33)$ is in very good agreement with the substitution (3), ${ }^{\mathrm{Y}} \mathrm{Cr}$ should be mainly bonded to ${ }^{\mathrm{O}} \mathrm{O}^{2-}$ rather than to ${ }^{\mathrm{O} 1}(\mathrm{OH}, \mathrm{F})$ according to the cluster: $\left[{ }^{\mathrm{O} 1}\left(\mathrm{O}^{2-}\right){ }^{\mathrm{Y}}(\mathrm{Cr})-{ }^{\mathrm{O} 3}(\mathrm{OH}){ }^{-}{ }^{\mathrm{Z}}(R+R)\right]$.

The bands at $3565 \mathrm{~cm}^{-1}$ and $3519 \mathrm{~cm}^{-1}$ can therefore be assumed to be associated with ${ }^{\mathrm{Y}} \mathrm{Mg}$ and ${ }^{\mathrm{Y}} \mathrm{Cr}$ (respectively). However, these absorption bands also show relations with the cations at the $Z$ site, which can be explained by the substitutions (1) and (2). The relation between $\mathrm{Cr}$ at $Z$ and PAI at $3565 \mathrm{~cm}^{-1}$ is displayed in Fig. 5a, indicating that this band first increases from oxy-chromium-dravite to chromo-alumino-povondraite with decreasing ${ }^{\mathrm{Z}} \mathrm{Cr}$ according to the substitution (1), ${ }^{\mathrm{Z}} \mathrm{Al} \rightarrow{ }^{\mathrm{Z}} \mathrm{Cr}$, and then continues to increase towards oxy-dravite but with increasing ${ }^{\mathrm{Z}} \mathrm{Al}$ (and ${ }^{\mathrm{Y}} \mathrm{Mg}$ ) according to the substitution (2): ${ }^{\mathrm{Y}}(2 \mathrm{Al}+\mathrm{Mg})+{ }^{\mathrm{Z}}(\mathrm{Al}) \rightarrow{ }^{\mathrm{Y}}(3 \mathrm{Cr})+{ }^{\mathrm{Z}}(\mathrm{Mg})$. A corresponding specular explanation can be given for the relation between $\mathrm{Cr}$ at $Z$ and PAI at $3519 \mathrm{~cm}^{-1}$ (Fig. 5b). This band decreases from oxy-chromium-dravite to chromo-alumino-povondraite with decreasing ${ }^{\mathrm{Z}} \mathrm{Cr}$ according to substitution (1), and then continues to decrease to oxy-dravite but with decreasing ${ }^{\mathrm{Y}} \mathrm{Cr}$ according to substitution (2). The correlation between Al at $Z$ and PAI at $3565 \mathrm{~cm}^{-1}$ (Fig. 5c) can be explained in a similar way. This band increases from oxy-chromium-dravite to chromo-alumino-povondraite with increasing ${ }^{\mathrm{Z}} \mathrm{Al}$ according to substitution (1), and then continues to increase to oxy-dravite with increasing ${ }^{\mathrm{Z}} \mathrm{Al}$ (and ${ }^{\mathrm{Y}} \mathrm{Mg}$ ) according to substitution (2). A specular explanation can also be given for the correlation between $\mathrm{Al}$ at $Z$ and PAI at $3519 \mathrm{~cm}^{-1}$ (Fig. 5d). This band decreases from oxy-chromium-dravite to chromo-alumino-povondraite with increasing ${ }^{\mathrm{Z}} \mathrm{Al}$ according to the substitution (1), and then it continues to decrease to oxy-dravite but with decreasing ${ }^{\mathrm{Y}} \mathrm{Cr}$ according to substitution (2). The occurrence of a negative correlation between ${ }^{\mathrm{Z}} \mathrm{Mg}$ and the PAI at $3565 \mathrm{~cm}^{-1}$ (Fig. 5e) from oxy-chromium-dravite to oxy-dravite can be explained by the substitution (3), 
${ }^{\mathrm{Y}}(2 \mathrm{Al}+\mathrm{Mg})+{ }^{\mathrm{Z}}(5 \mathrm{Al}) \rightarrow{ }^{\mathrm{Y}}(3 \mathrm{Cr})+{ }^{\mathrm{Z}}(4 \mathrm{Cr}+\mathrm{Mg})$, which decrease ${ }^{\mathrm{Z}} \mathrm{Mg}$ and increase ${ }^{\mathrm{Y}} \mathrm{Mg}$. Likewise, the positive correlation between ${ }^{\mathrm{Z}} \mathrm{Mg}$ and the PAI at $3519 \mathrm{~cm}^{-1}$ (Fig. $5 \mathrm{f}$ ) is linked to ${ }^{\mathrm{Y}}(3 \mathrm{Cr})+{ }^{\mathrm{Z}}(4 \mathrm{Cr}+\mathrm{Mg}) \rightarrow{ }^{\mathrm{Y}}(2 \mathrm{Al}+\mathrm{Mg})+{ }^{\mathrm{Z}}(5 \mathrm{Al})$, which increases both ${ }^{\mathrm{Z}} \mathrm{Mg}$ and ${ }^{\mathrm{Y}} \mathrm{Cr}$.

In summary, the band at $3565 \mathrm{~cm}^{-1}$ can be ascribed to the clusters $\left[{ }^{\mathrm{Ol}}\left(\mathrm{O}^{2-}\right)-{ }^{\mathrm{Y}}(\mathrm{Mg})-\right.$ $\left.{ }^{\mathrm{O} 3}(\mathrm{OH}){ }^{\mathrm{Z}}\left(\mathrm{Al}_{1.7} \mathrm{Mg}_{0.3)}\right)\right]_{0.7}$ and $\left[{ }^{\mathrm{O}}(\mathrm{OH}, \mathrm{F})-{ }^{\mathrm{Y}}(\mathrm{Mg})-{ }^{\mathrm{O}}(\mathrm{OH}){ }^{\mathrm{Z}}(\mathrm{AlAl})\right]_{0.3}$ which represent the oxy-dravite and (fluor-)dravite components (respectively), whereas the band at $3519 \mathrm{~cm}^{-1}$ can be ascribed to $\left[{ }^{\mathrm{Ol}}\left(\mathrm{O}^{2-}\right)-{ }^{\mathrm{Y}}(\mathrm{Cr})-{ }^{\mathrm{O} 3}(\mathrm{OH})-{ }^{\mathrm{Z}}\left(\mathrm{Al}_{1.3} \mathrm{Mg}_{0.7}\right)_{\Sigma 2.0}\right]$ and $\left[{ }^{\mathrm{O}}\left(\mathrm{O}^{2-}\right)_{-}{ }^{\mathrm{Y}}(\mathrm{Cr})^{-}{ }^{\mathrm{O} 3}(\mathrm{OH})-\right.$ $\left.\left.\mathrm{Z}_{(} \mathrm{Cr}_{1.3} \mathrm{Mg}_{0.7}\right)\right]$ which represent the chromo-alumino-povondraite and oxy-chromium-dravite components (respectively).

\section{$(\mathrm{OH})$ band assignment}

Each of the more frequent local arrangements around the two types of $(\mathrm{OH})$ groups, which occupy the two different crystallographic sites $\mathrm{O} 1$ and $\mathrm{O} 3$, is expected to produce an absorption band in the FTIR and Raman spectra. As above mentioned, The O1 site is surrounded by three $Y$ cations, whereas the $\mathrm{O} 3$ site is surrounded by one $Y$ and two $Z$ cations. In addition, the occupancy of the $X$ site may also affect the absorption band related to O1 (Gonzalez-Carreño et al. 1988).

In our band assignment model, we assume that the frequency of the $(\mathrm{OH})$ stretching absorption bands is inversely related to the sum of charges of cations which are coordinated to the (OH) group (e.g., Martínez-Alonso et al. 2002; Bosi et al. 2012b). In accordance with Gatta et al. (2014), we also assume that: the ${ }^{\mathrm{O}}(\mathrm{OH})$ group forms a very weak hydrogen bond (bond strength $<0.05$ valence units), whereas the ${ }^{03}(\mathrm{OH})$ group forms a weak hydrogen bond (bond strength $\sim 0.11$ valence units) with the closest $\mathrm{O} 5$ atom $\left({ }^{03} \mathrm{O}-\right.$ $\left.{ }^{\mathrm{O} 3} \mathrm{H} \cdot \mathrm{OO} 5\right)$, and that the strength of the hydrogen bond will impact on the frequency of the principal (OH)-stretching vibration (e.g., Libowitzky 1999). Based on these criteria, we arrive at an assignment model for the observed main IR and Raman bands to stable shortrange arrangements as follows:

- the band at $3519 \mathrm{~cm}^{-1}$ is assigned to $\left.\left[{ }^{\mathrm{Y}} \mathrm{Cr}^{\mathrm{Z}}(\mathrm{Cr}, \mathrm{Al}){ }^{\mathrm{Z}}(\mathrm{Cr}, \mathrm{Al}, \mathrm{Mg})\right)\right]-{ }^{\mathrm{O}}(\mathrm{OH})$

- the band at $3565 \mathrm{~cm}^{-1}$ is assigned to $\left[{ }^{\mathrm{Y}} \mathrm{Mg}^{\mathrm{Z}} \mathrm{Al}^{\mathrm{Z}}(\mathrm{Al}, \mathrm{Mg})\right]-{ }^{03}(\mathrm{OH})$

- the weak bands at $3712-3762 \mathrm{~cm}^{-1}$ are assigned to ${ }^{\mathrm{Y}}\left[\mathrm{Mg} \mathrm{Mg}\left(\mathrm{Mg}, R^{3+}\right)\right]-{ }^{\mathrm{O}}(\mathrm{OH})$ where $R^{3+}$ is a group of trivalent cations at the $Y$ sites. 


\section{Concluding remarks}

The fundamental $(\mathrm{OH})$-stretching bands in IR spectra of tourmalines display pronounced pleochroism (anisotropic intensities) with very strong absorption for spectra polarized along the c-axis (e.g., Gebert and Zemann 1965) owing to the orientation of the (OH) dipoles, which is approximately parallel to the c-axis direction (e.g., Gatta et al. 2014). This causes severe experimental problems for the identification of absorption bands related to the $\mathrm{O} 3$ site of tourmaline, as it is generally not possible to thin crystals sufficiently to avoid offscale intensity of these bands. Raman spectra are normally not affected by this problem, but may suffer from fluorescence effects. In this study, we showed that the combination of single crystal FTIR and Raman spectra collected with $\mathbf{E} / / \mathbf{c}$ and $\mathbf{E} \perp \mathbf{c}$ (respectively) may provide a useful characterization of the local $(\mathrm{OH})$ environments around the $\mathrm{O} 3$ site. Very good correlations were found between the obtained PAI at 3519 and $3565 \mathrm{~cm}^{-1}$ derived from short-range information and the site populations derived from long-range information (i.e., SREF and EMPA). For the system oxy-dravite - chromo-alumino-povondraite - oxychromium-dravite, the band at $3519 \mathrm{~cm}^{-1}$ was shown to be associated with ${ }^{\mathrm{Y}} \mathrm{Cr}-\mathrm{O} 3-(Z+$ $Z$ ), while the band at $3565 \mathrm{~cm}^{-1}$ was shown to be associated with ${ }^{\mathrm{Y}} \mathrm{Mg}-\mathrm{O} 3-(Z+Z)$.

Acknowledgments Chemical analyses were done with the kind assistance of Marcello Serracino to whom the authors express their gratitude. Leonid Reznitskii was supported by a grant from the Russian Foundation for Basic Research (project 13-05-00258).

\section{References}

Bosi F (2010) Octahedrally coordinated vacancies in tourmaline: a theoretical approach. Mineral Mag 74:1037-1044 
Bosi F (2011) Stereochemical constraints in tourmaline: from a short-range to a long-range structure. Can Mineral 49:17-27

Bosi F (2013) Bond-valence constraints around the O1 site of tourmaline. Mineral Mag 77: 343-351.

Bosi F, Lucchesi S (2004) Crystal chemistry of the schorl-dravite series. Eur J Mineral 16: $335-344$.

Bosi F, Lucchesi S (2007) Crystal chemical relationships in the tourmaline group: Structural constraints on chemical variability. Am Mineral 92:1054-1063

Bosi F, Skogby H (2013) Oxy-dravite, $\mathrm{Na}\left(\mathrm{Al}_{2} \mathrm{Mg}\right)\left(\mathrm{Al}_{5} \mathrm{Mg}\right)\left(\mathrm{Si}_{6} \mathrm{O}_{18}\right)\left(\mathrm{BO}_{3}\right)_{3}(\mathrm{OH})_{3} \mathrm{O}$, a new mineral species of the tourmaline supergroup. Am Mineral 98: 1442-1448

Bosi F, Lucchesi S, Reznitskii L (2004) Crystal chemistry of the dravite-chromdravite series. Eur J Mineral 16: 345-352

Bosi F, Balić-Žunić T, Surour AA (2010) Crystal structure analysis of four tourmalines from the Cleopatra's Mines (Egypt) and Jabal Zalm (Saudi Arabia), and the role of Al in the tourmaline group. Am Mineral 95:510-518

Bosi F, Reznitskii L, Skogby H (2012a) Oxy-chromium-dravite, $\mathrm{NaCr}_{3}\left(\mathrm{Cr}_{4} \mathrm{Mg}_{2}\right)\left(\mathrm{Si}_{6} \mathrm{O}_{18}\right)\left(\mathrm{BO}_{3}\right)_{3}(\mathrm{OH})_{3} \mathrm{O}$, a new mineral species of the tourmaline supergroup. Am Mineral 97: 2024-2030

Bosi F, Skogby H, Agrosì G, Scandale E (2012b) Tsilaisite, $\mathrm{NaMn}_{3} \mathrm{Al}_{6}\left(\mathrm{Si}_{6} \mathrm{O}_{18}\right)\left(\mathrm{BO}_{3}\right)_{3}(\mathrm{OH})_{3} \mathrm{OH}$, a new mineral species of the tourmaline supergroup from Grotta d'Oggi, San Pietro in Campo, island of Elba, Italy. Am Mineral 97:989-994

Bosi F, Skogby H, Hålenius U, Reznitskii L (2013) Crystallographic and spectroscopic characterization of Fe-bearing chromo-alumino-povondraite and its relations with oxy-chromium-dravite and oxy-dravite. Am Mineral 98: 1557-1564

Bosi F, Skogby H, Reznitskii L, Hålenius U (2014) Vanadio-oxy-dravite, $\mathrm{NaV}_{3}\left(\mathrm{Al}_{4} \mathrm{Mg}_{2}\right)\left(\mathrm{Si}_{6} \mathrm{O}_{18}\right)\left(\mathrm{BO}_{3}\right)_{3}(\mathrm{OH})_{3} \mathrm{O}$, a new mineral species of the tourmaline supergroup. Am Mineral 99: 218-224

Castañeda C, Oliveira EF, Gomes N, Soares ACP (2000) Infrared study of OH in tourmaline from the elbaite-schorl series. Am Mineral 85:1503-1507

Ertl A, Hughes JM, Pertlik F, Foit FF Jr, Wright SE, Brandstatter F, Marler B (2002) Polyhedron distortions in tourmaline. Can Mineral 40:153-162 
Fantini C, Tavares MC, Krambrock K, Moreira RL, Righi A (2014) Raman and infrared study of hydroxyl sites in natural uvite, fluor-uvite, magnesio-foitite, dravite and elbaite tourmalines. Phys Chem Minerals 41: 247-254

Filip J, Bosi F, Novák M, Skogby H, Tuček J, Čuda J, Wildner M. (2012) Redox processes of iron in the tourmaline structure: example of the high-temperature treatment of $\mathrm{Fe}^{3+}$ rich schorl. Geochim Cosmochim Acta 86:239-256

Foit FF Jr (1989) Crystal chemistry of alkali-deficient schorl and tourmaline structural relationships. Am Mineral 74:422-431

Gatta GD, Bosi F, McIntyre GJ, Skogby H (2014) First accurate location of two proton sites in tourmaline: A single-crystal neutron diffraction study of oxy-dravite. Mineral Mag 78: 681-692

Gebert W, Zemann J (1965) Messung des Ultrarot-Pleochroismus von Mineralen II. Der Pleochroismus der OH-Streckfrequenz in Turmalin. Neues Jahrb Mineral Monatsh $8: 232-235$

Gonzalez-Carreño T, Fernandez M, Sanz J (1988) Infrared and electron microprobe analysis of tourmalines. Phy Chem Minerals 15:452-460

Grice JD, Ercit TS (1993) Ordering of Fe and Mg in the tourmaline crystal structure: the correct formula. Neues Jahrb Mineral Abh 165:245-266

Hawthorne FC (1996) Structural mechanisms for light-element variations in tourmaline. Can Mineral 34:123-132

Hawthorne FC (2002) Bond-valence constraints on the chemical composition of tourmaline. Can Mineral 40:789-797

Hawthorne FC, Henry DJ (1999) Classification of the minerals of the tourmaline group. Eur J Mineral 11:201-215

Henry DJ, Novák M, Hawthorne FC, Ertl A, Dutrow B, Uher P, Pezzotta F (2011) Nomenclature of the tourmaline supergroup minerals. Am Mineral 96: 895-913.

Hoang LH, Hien NTM, Chen XB, Minh NV, Yang I-S (2011) Raman spectroscopic study of various types of tourmalines. J Raman Spec 42:1442-1446

Libowitzky E, (1999) Correlation of $\mathrm{O}-\mathrm{H}$ stretching frequencies and $\mathrm{O}-\mathrm{H}{ }^{\cdots} \mathrm{O}$ hydrogen bond lengths in minerals. Monatsh Chemie 130:1047-1059

Lussier AJ, Hawthorne FC, Aguiar PM, Michaelis VK, Kroeker S (2011) Elbaiteliddicoatite from Black Rapids glacier, Alaska. Period Mineral 80:57-73 
Martìnez-Alonso S, Rustad JR, Goetz AFH (2002) Ab initio quantum mechanical modeling of infrared vibrational frequencies of the $\mathrm{OH}$ group in dioctahedral phyllosilicates. Part II: Main physical factors governing the $\mathrm{OH}$ vibrations. Am Mineral 87:12241234

Pouchou JL, Pichoir F (1991) Quantitative analysis of homogeneous or stratified microvolumes applying the model "PAP." In K.F.J. Heinrich and D.E. Newbury, Eds., Electron Probe Quantitation, p. 31-75. Plenum, New York

Reznitskii L, Clark CM, Hawthorne FC, Grice JD, Skogby H, Hålenius U, Bosi F (2014) Chromo-alumino-povondraite, $\mathrm{NaCr}_{3}\left(\mathrm{Al}_{4} \mathrm{Mg}_{2}\right)\left(\mathrm{Si}_{6} \mathrm{O}_{18}\right)\left(\mathrm{BO}_{3}\right)_{3}(\mathrm{OH})_{3} \mathrm{O}$, a new mineral species of the tourmaline supergroup. Am Mineral 99: 1767-1773

Sheldrick G M (2013) SHELXL2013. University of Göttingen, Germany

Skogby H, Bosi F, Lazor P (2012) Short-range order in tourmaline: a vibrational spectroscopic approach to elbaite. Phy Chem Minerals 39: 811-816

Wright SE, Foley JA, Hughes JM (2000) Optimization of site occupancies in minerals using quadratic programming. Am Mineral 85: 524-531 


\section{List of tables}

Table 1. Methodologies used to characterize the six oxy-tourmaline samples used in this study and references.

Table 2. Single-crystal X-ray diffraction data details for oxy-chromium-dravite (T89104) and oxy-dravite (PR108).

Table 3. Fractional atom coordinates and site occupancy for oxy-chromium-dravite (T89104) and oxy-dravite (PR108).

Table 4. Displacement parameters $\left(\AA^{2}\right)$ for oxy-chromium-dravite (T89104) and oxydravite (PR108).

Table 5. Selected bond distances $(\AA)$ for oxy-chromium-dravite (T89104) and oxy-dravite (PR108).

Table 6. Chemical composition for oxy-chromium-dravite (T89104) and oxy-dravite (PR108).

Table 7. Cation site populations (apfu), mean atomic numbers and mean bond lengths ( $(\AA)$ for oxy-chromium-dravite (T89104) and oxy-dravite (PR108).

Table 8. Structural formulae of six oxy-tourmalines used in this study.

Table 9. Sample thicknesses and relative peak area intensities for infrared- and Ramanbands

\section{List of figures and figure captions}

Figure 1. FTIR spectra polarized parallel (a) and perpendicular (b) to the c-axis direction. From top to bottom: sample PR108, PR107, Tm1p43e, PR85v, Tmt6b and T89104. Dotted spectra indicate the two fitted bands for the T89104 spectrum. Spectra are vertically offset for clarity.

Figure 2. Raman spectra polarized parallel to the c-axis direction. From top to bottom: sample PR107, Tm1p43e, PR85v and T89104. Spectra are vertically offset for clarity. 
Figure 3. Ternary diagram of the $\mathrm{V}_{\text {total }}-\mathrm{Cr}_{\text {total }}-\mathrm{Al}_{\text {total }}$ subsystem for oxy-tourmaline $\mathrm{Na}^{\mathrm{Y}}\left(R^{3+}\right)_{3}{ }^{\mathrm{Z}}\left(R_{4}{ }^{3+} \mathrm{Mg}_{2}\right) \mathrm{Si}_{6} \mathrm{O}_{18}\left(\mathrm{BO}_{3}\right)_{3}(\mathrm{OH})_{3} \mathrm{O}$. The solid black circles represent the samples used in this study. $\mathrm{Cr}_{5} \mathrm{Al}_{2}$ and $\mathrm{Cr}_{1.5} \mathrm{Al}_{5.5}$ indicate the borderlines between oxy-chromium-dravite and chromo-alumino-povondraite and between oxy-dravite and chromo-alumino-povondraite, respectively.

Figure 4. (a) PAI for the $3565 \mathrm{~cm}^{-1}$ band versus $\mathrm{Mg}$ at $Y$. Dashed lines indicate expected correlation for ideal solid-solution between oxy-chromium-dravite-oxy-dravite and oxy-chromium-dravite-(fluor-)dravite. (b) PAI for the $3519 \mathrm{~cm}^{-1}$ band versus $\mathrm{Cr}$ at $Y$. Dashed line indicates expected correlation for ideal solidsolution between oxy-dravite and oxy-chromium-dravite. Solid lines are linear regressions for the experimental data fitted through the origin.

Figure 5. Plots of peak area distribution for the $3565 \mathrm{~cm}^{-1}$ and $3519 \mathrm{~cm}^{-1}$ bands versus cation occupancy at the $Z$ site. Solid lines are guide for the eye, dashed lines represent a linear distribution between the end-members. (a) PAI for the 3519 $\mathrm{cm}^{-1}$ band versus $\mathrm{Cr}$ at $Z$. (b) PAI for the $3519 \mathrm{~cm}^{-1}$ band versus $\mathrm{Cr}$ at $Z$. (c) PAI for the $3565 \mathrm{~cm}^{-1}$ band versus $\mathrm{Al}$ at $Z$. (d) PAI for $3519 \mathrm{~cm}^{-1}$ band versus $\mathrm{Al}$ at $Z$. (e) PAI for the $3565 \mathrm{~cm}^{-1}$ band versus $\mathrm{Mg}$ at $Z$. (f) PAI for the 3519 $\mathrm{cm}^{-1}$ band versus $\mathrm{Mg}$ at $Z$. See text for further explanation. 
Figure 1

Click here to download high resolution image
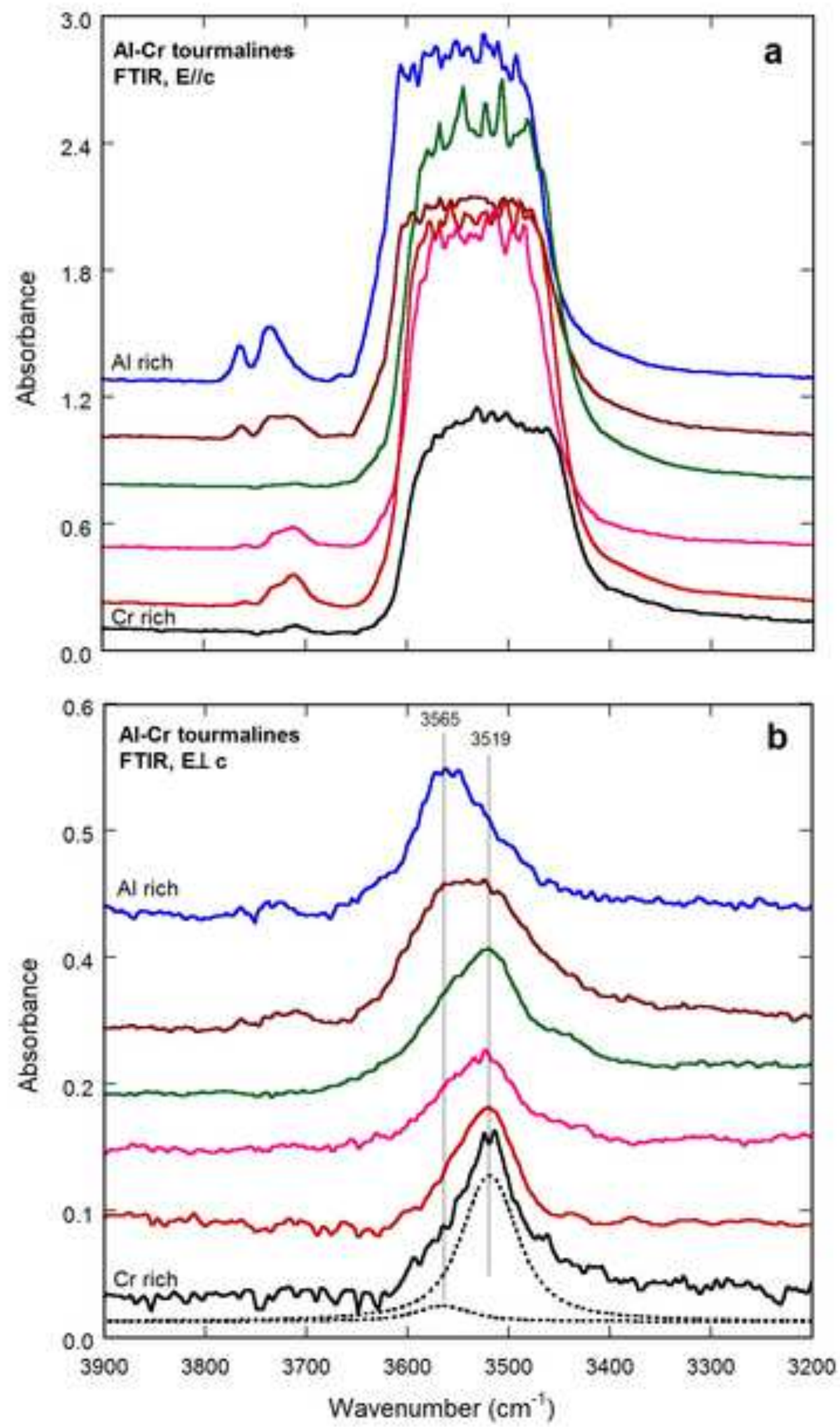


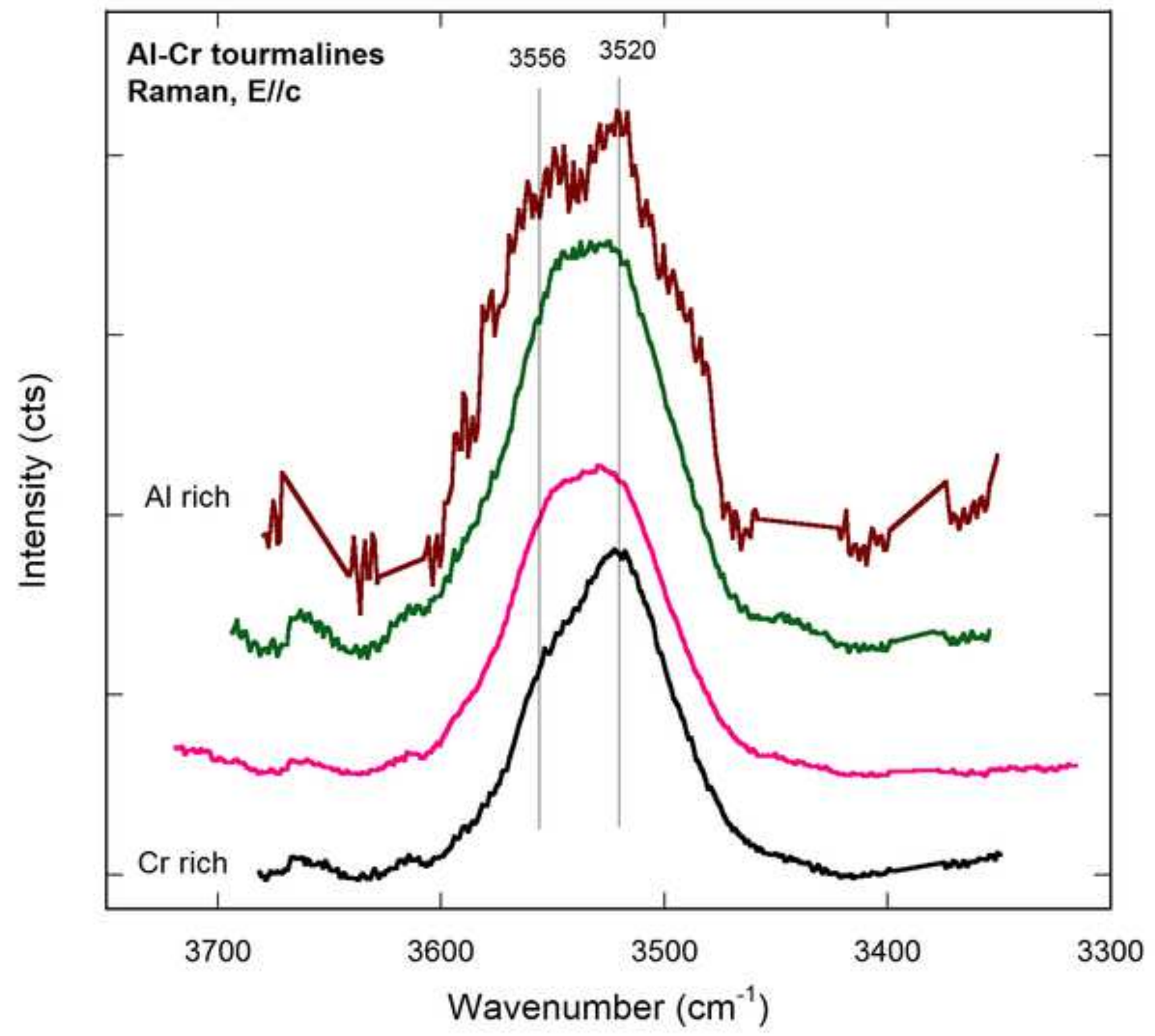




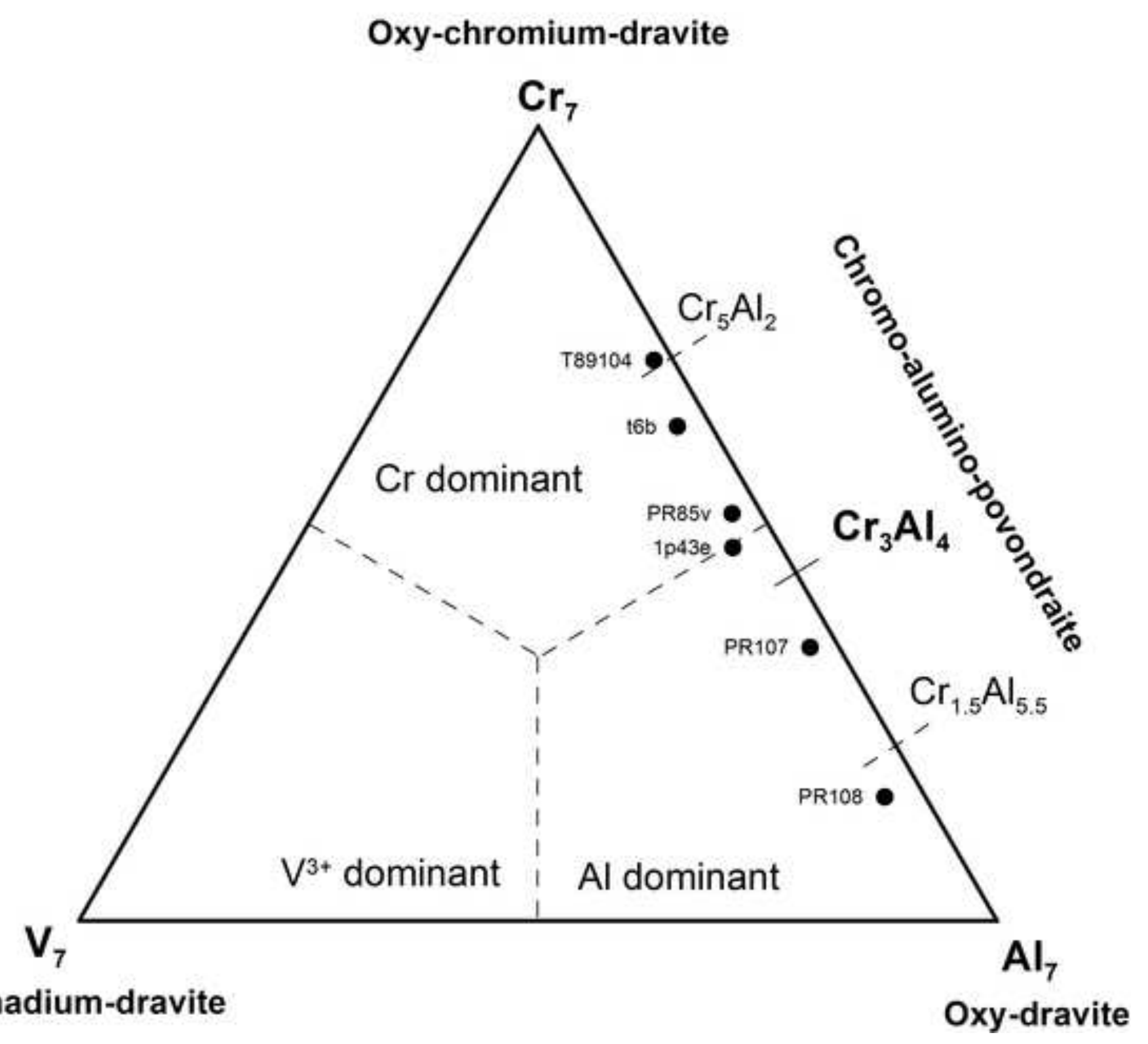


Figure 4

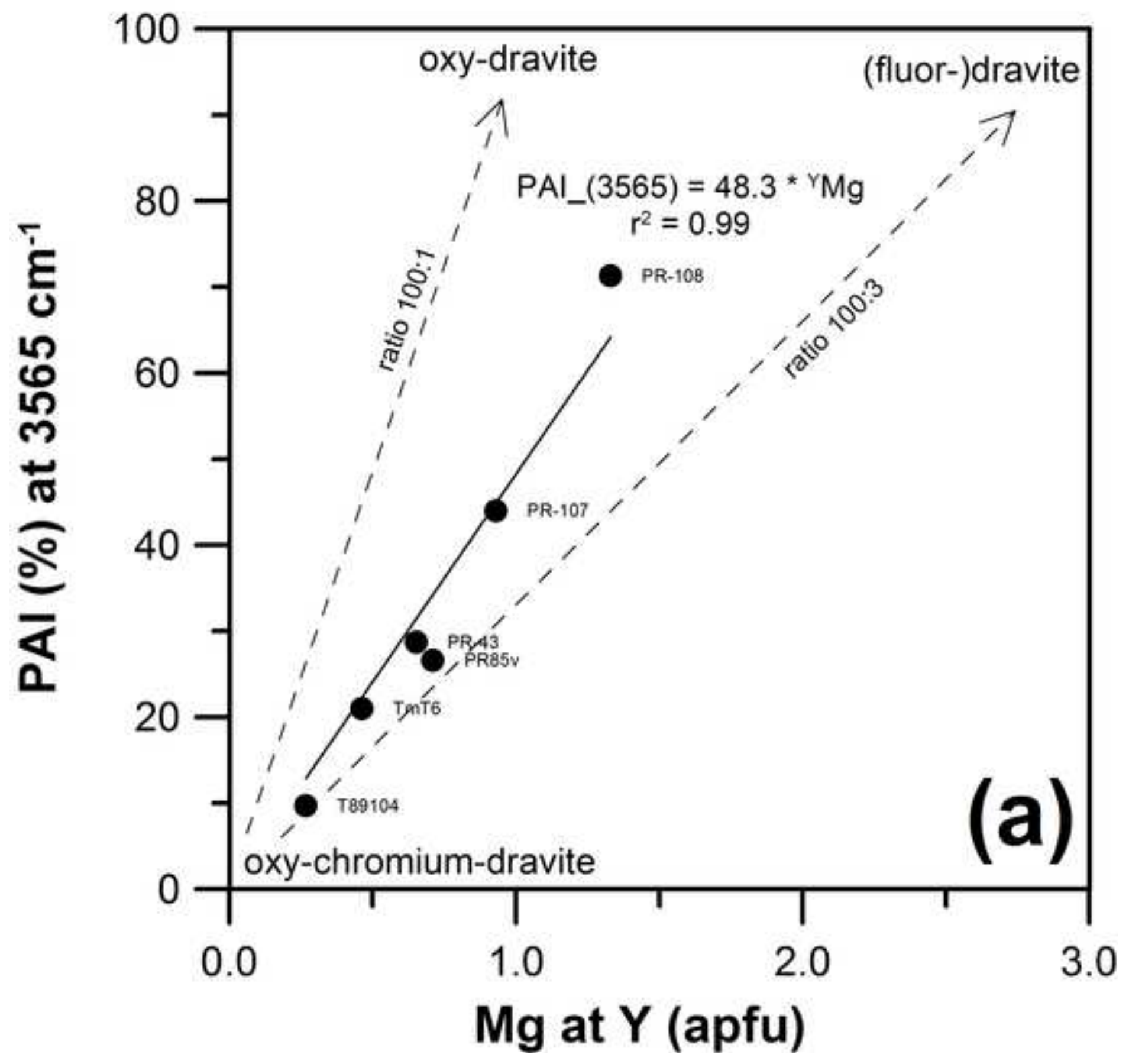


Figure 4

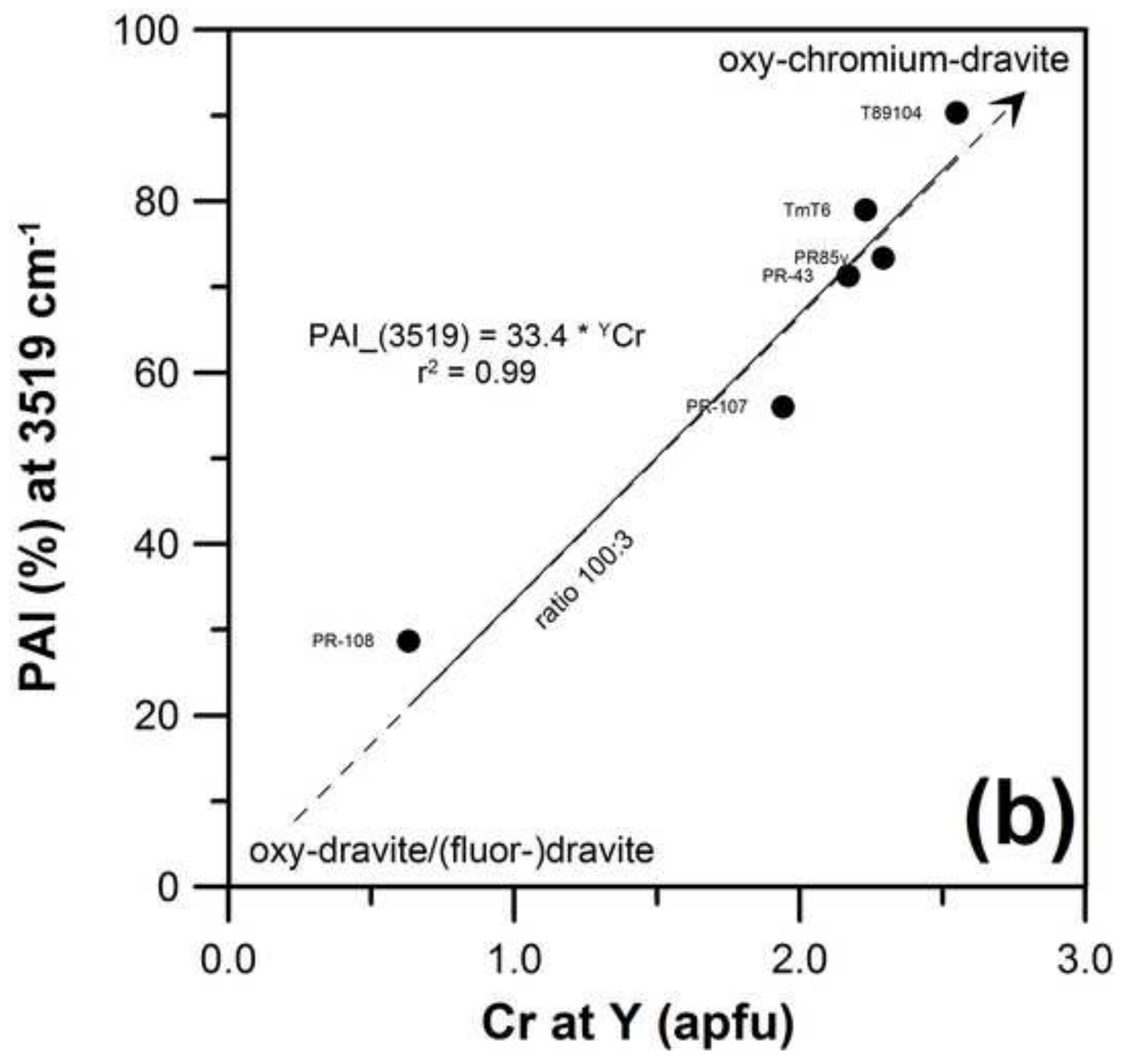


Figure 5

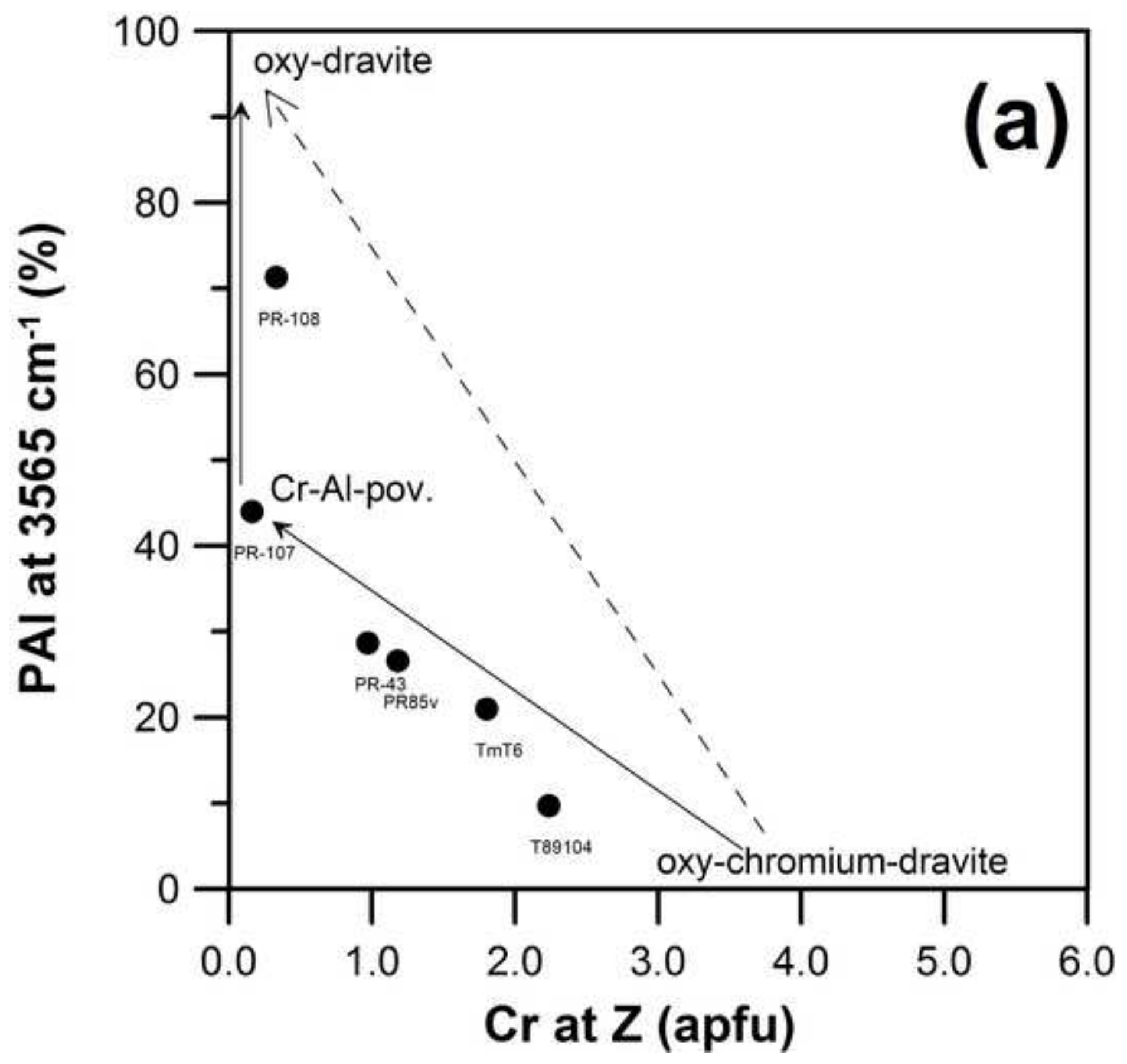


Figure 5

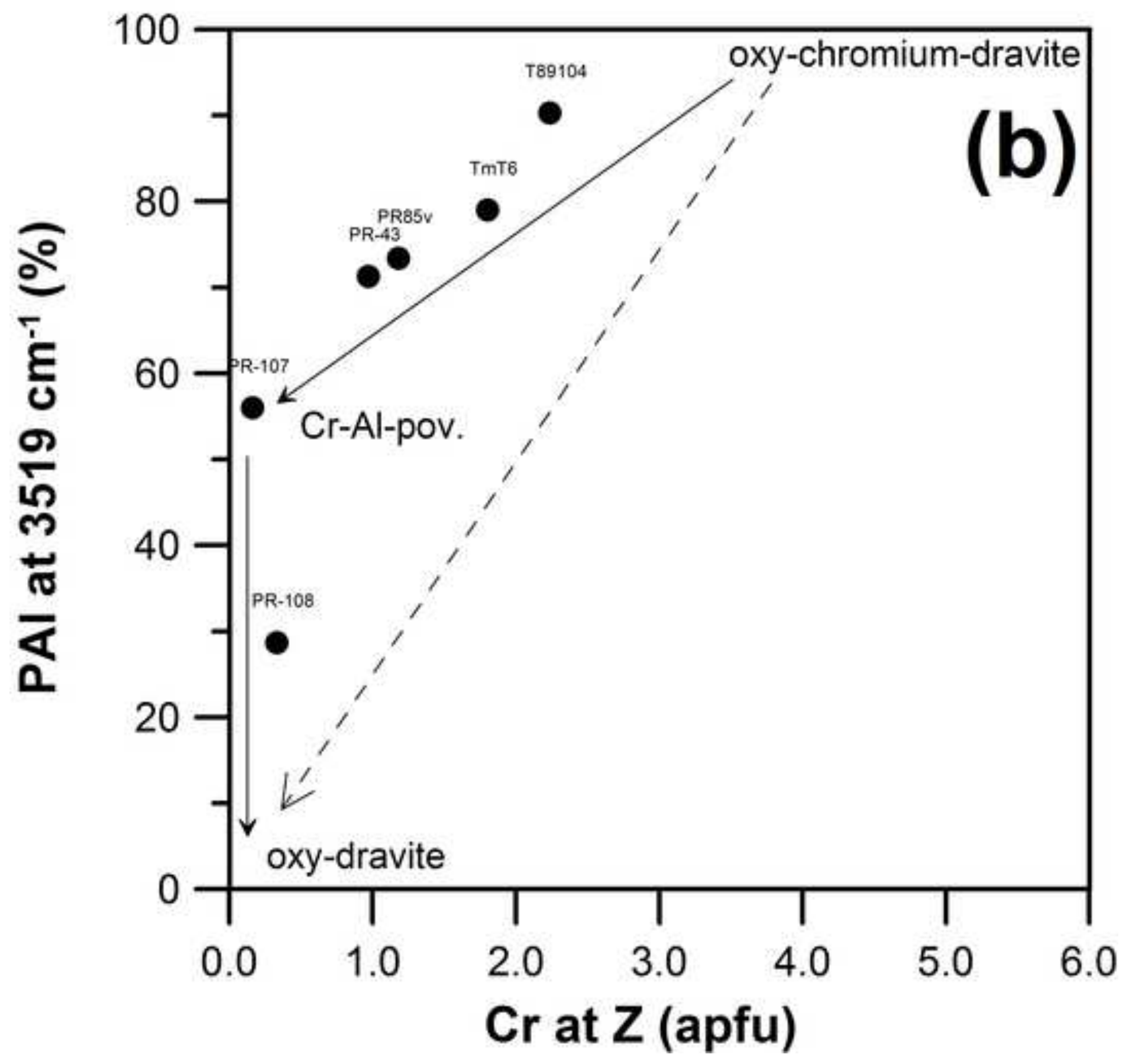


Figure $5 c$

Click here to download high resolution image

Figure 5

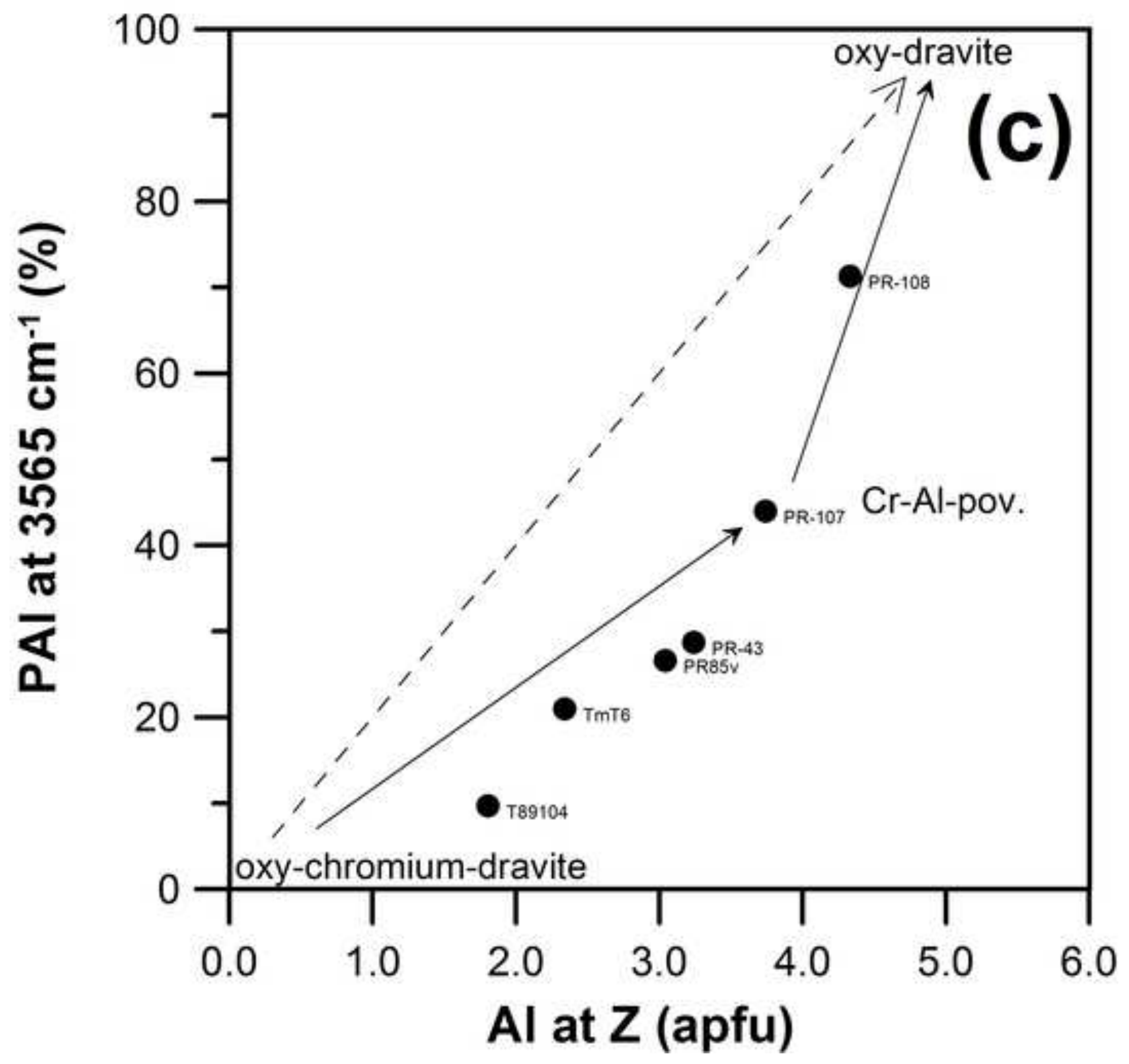


Figure 5

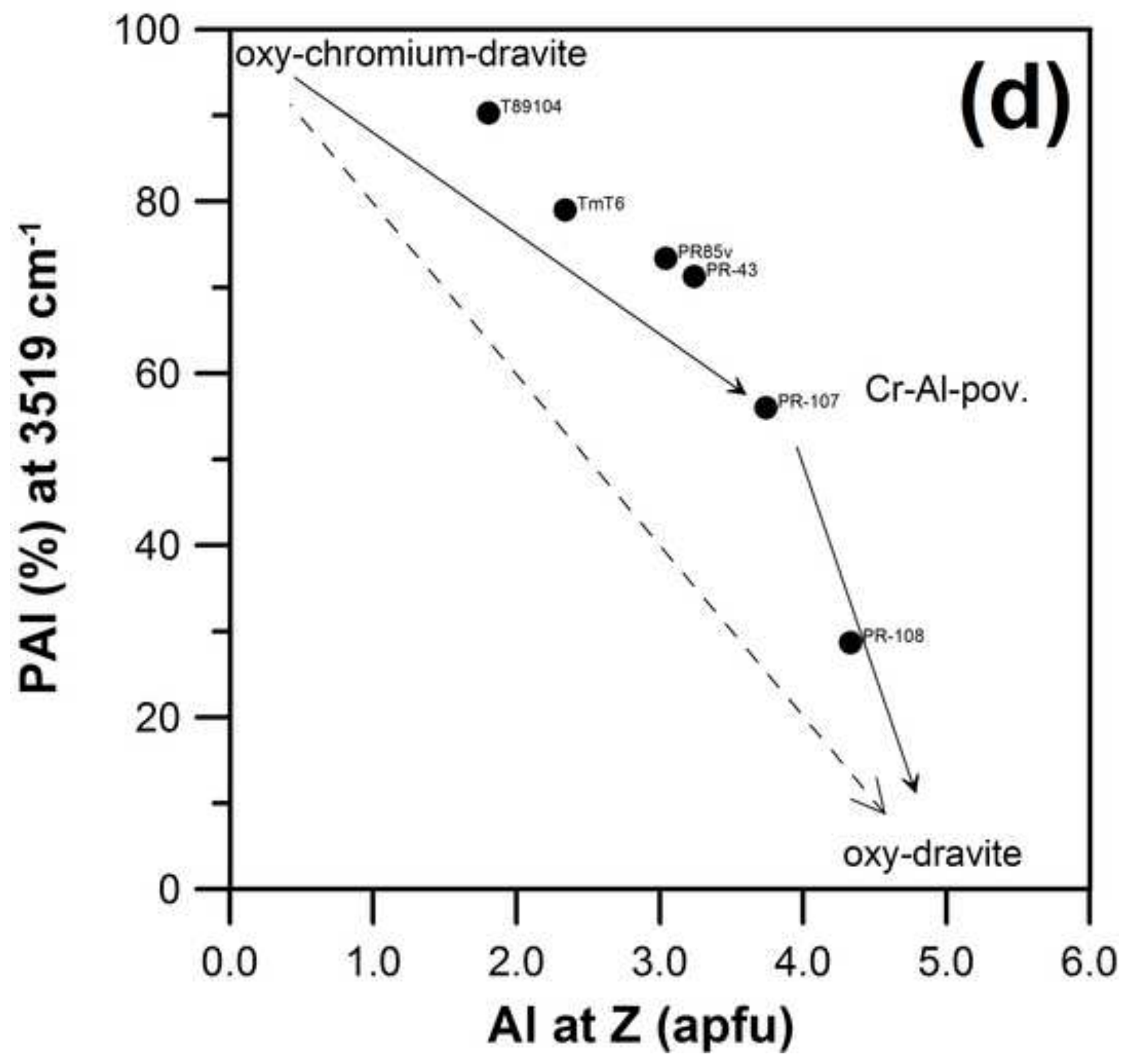


Figure 5

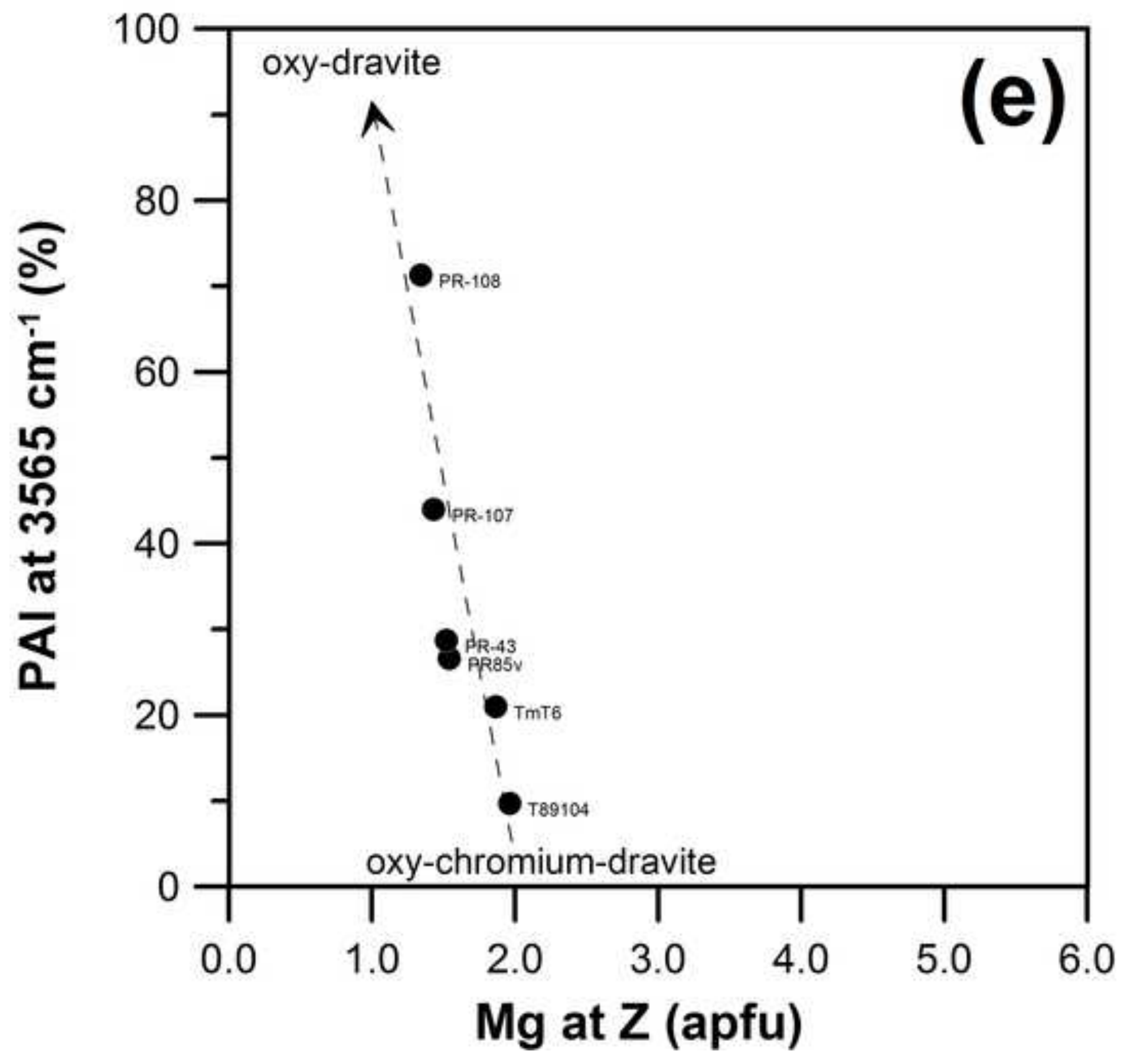


Figure $5 f$

Click here to download high resolution image

Figure 5

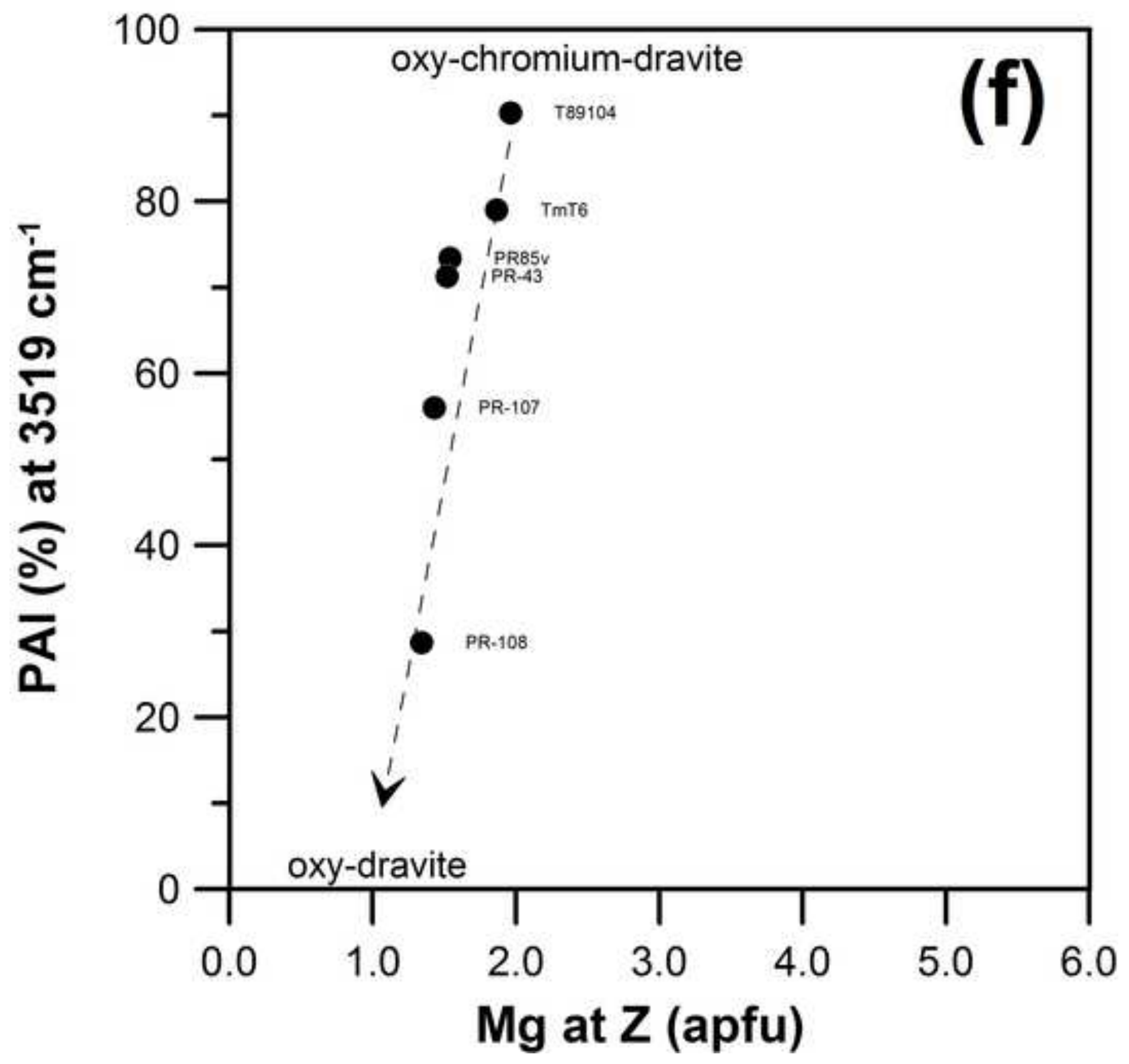


Figure 1

Click here to download high resolution image
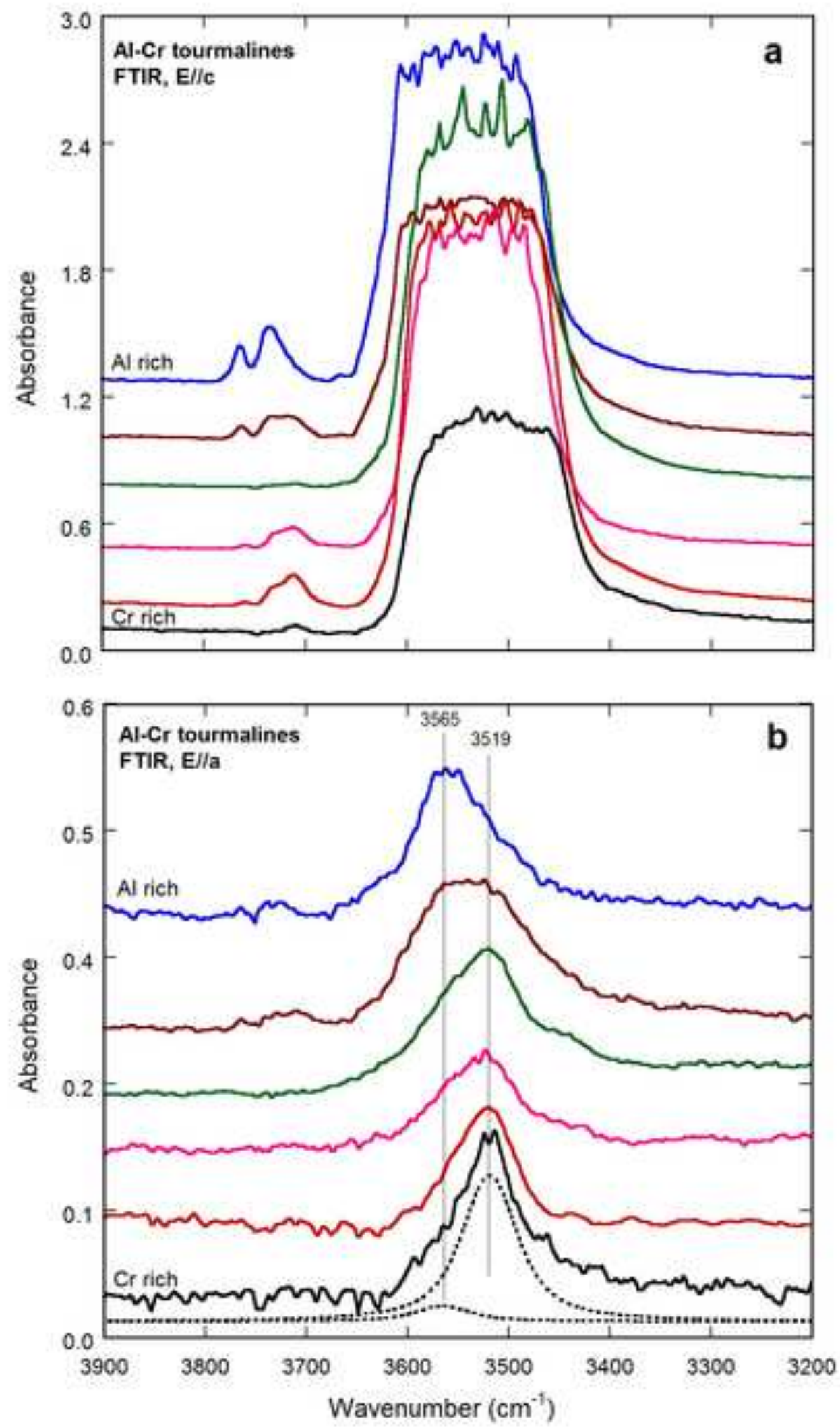
TABLE 2. Single-crystal X-ray diffraction data details for oxy-chromium-dravite (T89104) and oxy-dravite (PR108)

\begin{tabular}{lll}
\hline Sample & T89104 & PR108 \\
\hline Crystal size $(\mathrm{mm})$ & $0.11 \times 0.18 \times 0.20$ & $0.15 \times 0.17 \times 0.25$ \\
$a(\AA)$ & $16.0572(3)$ & $15.9710(2)$ \\
$c(\AA)$ & $7.33280(10)$ & $7.22710(10)$ \\
$V\left(\AA^{3}\right)$ & $1637.34(5)$ & $1596.46(5)$ \\
Range for data collection, $2 \theta\left(^{\circ}\right)$ & $5-73$ & $5-65$ \\
Reciprocal space range $h k l$ & $-26 \leq h \leq 24$ & $-24 \leq h \leq 22$ \\
& $-23 \leq k \leq 26$ & $-24 \leq k \leq 20$ \\
& $-6 \leq l \leq 12$ & $-9 \leq l \leq 10$ \\
Total number of frames & 1469 & 3265 \\
Set of measured reflections & 5024 & 6874 \\
Unique reflections, $R_{\text {int }}(\%)$ & $1416,1.46$ & $1354,1.86$ \\
Redundancy & 5 & 10 \\
Absorption correction method & SADABS & SADABS \\
Refinement method & Full-matrix last-squares on $F^{2}$ & Full-matrix last-squares on $F^{2}$ \\
Structural refinement program & SHELXL-2013 & SHELXL-2013 \\
Extinction coefficient & $0.00062(8)$ & $0.0003(2)$ \\
Flack parameter & $0.07(2)$ & $0.07(4)$ \\
$w R 2(\%)$ & 2.79 & 3.99 \\
$R 1(\%)$ all data & 1.29 & 1.63 \\
$R 1(\%)$ for $I>2 \sigma(I)$ & 1.28 & 1.60 \\
GooF & 1.096 & 1.073 \\
Largest diff. peak and hole $\left( \pm \mathrm{e}^{-} / \AA^{3}\right)$ & 0.42 and -0.26 & 0.34 and -0.28 \\
\hline
\end{tabular}

Notes: $R_{\text {int }}=$ merging residual value; $R 1=$ discrepancy index, calculated from $F$-data; $w R 2=$ weighted discrepancy index, calculated from $F^{2}$-data; GooF = goodness of fit; Diff. Peaks = maximum and minimum residual electron density.

Radiation, $\mathrm{Mo} K \alpha=0.71073 \AA$. Data collection temperature $=293 \mathrm{~K}$. Space group $R 3 m ; Z=3$. 
TABLE 3. Fractional atom coordinates and site occupancy for oxy-chromium-dravite (T89104) and oxy-dravite (PR108)

\begin{tabular}{|c|c|c|c|c|c|c|c|c|}
\hline \multirow{2}{*}{$\frac{\text { Sample }}{\text { Site }}$} & \multicolumn{3}{|c|}{ T89104 } & \multirow[b]{2}{*}{ Site occupancy } & \multicolumn{3}{|c|}{ PR108 } & \multirow[b]{2}{*}{ Site occupancy } \\
\hline & $x$ & $y$ & $z$ & & $x$ & $y$ & $z$ & \\
\hline$X$ & 0 & 0 & $0.22571(18)$ & $\mathrm{Na}_{1.029(7)}$ & 0 & 0 & $0.2285(2)$ & $\mathrm{Na}_{1.132(10)}$ \\
\hline$Y$ & $0.123327(16)$ & $0.061663(8)$ & $0.63791(6)$ & $\mathrm{Cr}_{0.906(4)} \mathrm{Mg}_{0.094(4)}$ & $0.12370(4)$ & $0.06185(2)$ & $0.63654(10)$ & $\mathrm{Cr}_{0.341(6)} \mathrm{Mg}_{0.659(2)}$ \\
\hline$Z$ & $0.297699(16)$ & $0.261729(17)$ & $0.60850(5)$ & $\mathrm{Cr}_{0.396(3)} \mathrm{Mg}_{0.604(3)}$ & $0.29807(4)$ & $0.26190(4)$ & $0.61116(10)$ & $\mathrm{Al}_{1.028(4)}$ \\
\hline$B$ & $0.10971(6)$ & $0.21943(12)$ & $0.4543(2)$ & $\mathrm{B}_{1.00}$ & $0.10995(10)$ & $0.21989(19)$ & $0.4538(4)$ & $\mathrm{B}_{1.00}$ \\
\hline$T$ & $0.189916(18)$ & $0.18822(2)$ & 0 & $\mathrm{Si}_{1.00}$ & $0.19128(3)$ & $0.18954(3)$ & 0 & $\mathrm{Si}_{1.00}$ \\
\hline $\mathrm{O} 1$ & 0 & 0 & $0.7652(2)$ & $\mathrm{O}_{1.00}$ & 0 & 0 & $0.7690(4)$ & $\mathrm{O}_{1.00}$ \\
\hline $\mathrm{O} 2$ & $0.06026(4)$ & $0.12052(7)$ & $0.48998(14)$ & $\mathrm{O}_{1.00}$ & $0.06067(6)$ & $0.12135(13)$ & $0.4848(3)$ & $\mathrm{O}_{1.00}$ \\
\hline $\mathrm{O} 3$ & $0.25583(8)$ & $0.12792(4)$ & $0.50932(15)$ & $\mathrm{O}_{1.00}$ & $0.26107(14)$ & $0.13053(7)$ & $0.5117(3)$ & $\mathrm{O}_{1.00}$ \\
\hline $\mathrm{O} 4$ & $0.09254(4)$ & $0.18509(9)$ & $0.07194(15)$ & $\mathrm{O}_{1.00}$ & $0.09264(7)$ & $0.18529(15)$ & $0.0717(3)$ & $\mathrm{O}_{1.00}$ \\
\hline O5 & $0.18281(8)$ & $0.09141(4)$ & $0.09112(14)$ & $\mathrm{O}_{1.00}$ & $0.18263(14)$ & $0.09131(7)$ & $0.0918(3)$ & $\mathrm{O}_{1.00}$ \\
\hline O6 & $0.19125(5)$ & $0.18199(5)$ & $0.78034(11)$ & $\mathrm{O}_{1.00}$ & $0.19406(9)$ & $0.18448(9)$ & $0.7787(2)$ & $\mathrm{O}_{1.00}$ \\
\hline $\mathrm{O} 7$ & $0.28301(5)$ & $0.28266(5)$ & $0.07273(11)$ & $\mathrm{O}_{1.00}$ & $0.28446(9)$ & $0.28403(8)$ & $0.07746(19)$ & $\mathrm{O}_{1.00}$ \\
\hline $\mathrm{O} 8$ & $0.20717(6)$ & $0.26765(6)$ & $0.43740(12)$ & $\mathrm{O}_{1.00}$ & $0.20886(9)$ & $0.26956(9)$ & $0.4401(2)$ & $\mathrm{O}_{1.00}$ \\
\hline $\mathrm{H} 3$ & $0.2554(16)$ & $0.1277(8)$ & $0.393(3)$ & $\mathrm{H}_{1.00}$ & $0.257(3)$ & $0.1287(13)$ & $0.402(5)$ & $\mathrm{H}_{1.00}$ \\
\hline
\end{tabular}


TABLE 4. Displacement parameters $\left(\AA^{2}\right)$ for oxy-chromium-dravite (T89104) and oxy-dravite (PR108)

\begin{tabular}{|c|c|c|c|c|c|c|c|}
\hline \multirow[b]{2}{*}{ Site } & $U^{11}$ & $U^{22}$ & $U^{33}$ & $U^{23}$ & $U^{13}$ & $U^{12}$ & $U_{\text {eq }} / U_{\text {iso }} *$ \\
\hline & & & & \multicolumn{4}{|l|}{ T89104 } \\
\hline$X$ & $0.0236(5)$ & $0.0236(5)$ & $0.0199(6)$ & 0 & 0 & $0.0118(3)$ & $0.0223(4)$ \\
\hline$Y$ & $0.00441(10)$ & $0.00434(8)$ & $0.00661(9)$ & $-0.00017(3)$ & $-0.00034(7)$ & $0.00221(5)$ & $0.00511(6)$ \\
\hline$Z$ & $0.00439(11)$ & $0.00480(11)$ & $0.00581(9)$ & $0.00044(7)$ & $-0.00004(7)$ & $0.00233(8)$ & $0.00498(6)$ \\
\hline$B$ & $0.0061(4)$ & $0.0071(6)$ & $0.0092(5)$ & $0.0010(4)$ & $0.0005(2)$ & $0.0035(3)$ & $0.0074(2)$ \\
\hline$T$ & $0.00503(12)$ & $0.00458(11)$ & $0.00662(11)$ & $-0.00037(8)$ & $-0.00031(9)$ & $0.00229(9)$ & $0.00546(6)$ \\
\hline $\mathrm{O} 1$ & $0.0059(4)$ & $0.0059(4)$ & $0.0076(6)$ & 0 & 0 & $0.0029(2)$ & $0.0064(3)$ \\
\hline $\mathrm{O} 2$ & $0.0054(3)$ & $0.0051(4)$ & $0.0080(4)$ & $0.0011(3)$ & $0.00055(15)$ & $0.0026(2)$ & $0.00620(18)$ \\
\hline $\mathrm{O} 3$ & $0.0102(5)$ & $0.0107(4)$ & $0.0070(4)$ & $0.00038(17)$ & $0.0008(3)$ & $0.0051(2)$ & $0.00937(19)$ \\
\hline $\mathrm{O} 4$ & $0.0079(3)$ & $0.0166(5)$ & $0.0093(4)$ & $-0.0008(4)$ & $-0.00039(18)$ & $0.0083(3)$ & $0.01029(19)$ \\
\hline O5 & $0.0144(5)$ & $0.0069(3)$ & $0.0085(4)$ & $0.00064(18)$ & $0.0013(4)$ & $0.0072(3)$ & $0.00911(18)$ \\
\hline O6 & $0.0091(3)$ & $0.0064(3)$ & $0.0059(3)$ & $-0.0008(2)$ & $-0.0003(2)$ & $0.0038(3)$ & $0.00717(13)$ \\
\hline $\mathrm{O} 7$ & $0.0077(3)$ & $0.0060(3)$ & $0.0100(3)$ & $-0.0013(2)$ & $-0.0023(2)$ & $0.0007(3)$ & $0.00910(13)$ \\
\hline $\mathrm{O} 8$ & $0.0048(3)$ & $0.0084(3)$ & $0.0171(3)$ & $0.0030(3)$ & $0.0011(3)$ & $0.0029(3)$ & $0.01028(14)$ \\
\hline \multirow[t]{2}{*}{$\mathrm{H} 3$} & & & & & & & $0.014^{*}$ \\
\hline & & & & \multicolumn{4}{|l|}{ PR108 } \\
\hline$X$ & $0.0136(6)$ & $0.0136(6)$ & $0.0147(9)$ & 0 & 0 & $0.0068(3)$ & $0.0140(5)$ \\
\hline$Y$ & $0.0059(3)$ & $0.0046(2)$ & $0.0079(3)$ & $-0.00104(9)$ & $-0.00209(18)$ & $0.00293(14)$ & $0.00598(19)$ \\
\hline$Z$ & $0.0061(2)$ & $0.0064(2)$ & $0.0066(2)$ & $0.00035(17)$ & $-0.00021(16)$ & $0.00297(17)$ & $0.00641(14)$ \\
\hline$B$ & $0.0075(8)$ & $0.0081(10)$ & $0.0075(10)$ & $-0.0001(8)$ & $0.0000(4)$ & $0.0040(5)$ & $0.0076(4)$ \\
\hline$T$ & $0.0059(2)$ & $0.00550(19)$ & $0.0070(2)$ & $-0.00074(15)$ & $-0.00070(16)$ & $0.00264(15)$ & $0.00621(12)$ \\
\hline $\mathrm{O} 1$ & $0.0114(8)$ & $0.0114(8)$ & $0.0100(14)$ & 0 & 0 & $0.0057(4)$ & $0.0110(5)$ \\
\hline $\mathrm{O} 2$ & $0.0107(6)$ & $0.0066(7)$ & $0.0141(9)$ & $0.0010(6)$ & $0.0005(3)$ & $0.0033(4)$ & $0.0109(4)$ \\
\hline $\mathrm{O} 3$ & $0.0210(9)$ & $0.0151(6)$ & $0.0062(8)$ & $0.0004(3)$ & $0.0008(6)$ & $0.0105(5)$ & $0.0135(4)$ \\
\hline $\mathrm{O} 4$ & $0.0092(5)$ & $0.0188(9)$ & $0.0114(8)$ & $-0.0009(7)$ & $-0.0004(3)$ & $0.0094(5)$ & $0.0121(3)$ \\
\hline O5 & $0.0164(9)$ & $0.0084(5)$ & $0.0121(8)$ & $0.0012(3)$ & $0.0025(6)$ & $0.0082(4)$ & $0.0114(3)$ \\
\hline O6 & $0.0120(6)$ & $0.0105(5)$ & $0.0073(5)$ & $-0.0018(4)$ & $-0.0014(4)$ & $0.0061(4)$ & $0.0097(2)$ \\
\hline $\mathrm{O} 7$ & $0.0096(5)$ & $0.0081(5)$ & $0.0112(6)$ & $-0.0009(4)$ & $-0.0028(4)$ & $0.0019(4)$ & $0.0107(2)$ \\
\hline $\mathrm{O} 8$ & $0.0065(5)$ & $0.0100(6)$ & $0.0183(6)$ & $0.0024(4)$ & $0.0008(5)$ & $0.0039(5)$ & $0.0117(3)$ \\
\hline $\mathrm{H} 3$ & & & & & & & $0.02 *$ \\
\hline
\end{tabular}

Notes: Equivalent $\left(U_{\text {eq }}\right)$ and isotropic ( $\left.U_{\text {iso }}\right)$ displacement parameters; H-atom was constrained to have a $U_{\text {iso }} 1.5$ times the $U_{\text {eq }}$ value of the $\mathrm{O} 3$ oxygen. 
TABLE 5. Selected bond distances $(\AA)$ for oxy-chromiumdravite (T89104) and oxy-dravite (PR108)

\begin{tabular}{|c|c|c|}
\hline Sample & T89104 & PR108 \\
\hline$X-\mathrm{O} 2^{\mathrm{B}, \mathrm{F}}(\times 3)$ & $2.5620(14)$ & $2.500(2)$ \\
\hline$X-\mathrm{O}^{\mathrm{B}, \mathrm{F}}(\times 3)$ & $2.7271(12)$ & $2.712(2)$ \\
\hline$X-\mathrm{O} 4^{\mathrm{B}, \mathrm{F}}(\times 3)$ & $2.8099(13)$ & $2.802(2)$ \\
\hline$\langle X-\mathrm{O}\rangle$ & 2.700 & 2.673 \\
\hline$Y-\mathrm{O} 1$ & $1.9524(8)$ & $1.9607(16)$ \\
\hline$Y-\mathrm{O}^{\mathrm{C}}(\times 2)$ & $1.9764(8)$ & $1.9882(13)$ \\
\hline$Y-\mathrm{O} 2^{\mathrm{B}}(\times 2)$ & $2.0130(7)$ & $2.0186(13)$ \\
\hline$Y-\mathrm{O} 3$ & $2.0699(11)$ & $2.103(2)$ \\
\hline$\langle Y-\mathrm{O}\rangle$ & 2.000 & 2.014 \\
\hline$Z-O 8^{\mathrm{E}}$ & $1.9502(8)$ & $1.9066(13)$ \\
\hline$Z-O 7^{\mathrm{E}}$ & $1.9641(8)$ & $1.9205(14)$ \\
\hline Z-O8 & $1.9583(8)$ & $1.9358(14)$ \\
\hline Z-O6 & $1.9901(8)$ & $1.9236(14)$ \\
\hline $\mathrm{Z}-\mathrm{O} 7^{\mathrm{D}}$ & $1.9915(8)$ & $1.9637(13)$ \\
\hline $\mathrm{Z}-\mathrm{O} 3$ & $2.0379(5)$ & $2.0068(10)$ \\
\hline$\langle\mathrm{Z}-\mathrm{O}\rangle$ & 1.982 & 1.945 \\
\hline$B-\mathrm{O}^{\mathrm{A}}(\times 2)$ & $1.3609(11)$ & $1.3717(19)$ \\
\hline$B-\mathrm{O} 2$ & $1.400(2)$ & $1.381(3)$ \\
\hline$\langle B-\mathrm{O}\rangle$ & 1.374 & 1.375 \\
\hline$T-\mathrm{O} 7$ & $1.5974(7)$ & $1.5998(12)$ \\
\hline$T^{*-\mathrm{O} 6}$ & $1.6147(8)$ & $1.6032(15)$ \\
\hline$T-\mathrm{O} 4$ & $1.6269(4)$ & $1.6272(8)$ \\
\hline$T-\mathrm{O} 5$ & $1.6427(5)$ & $1.6443(9)$ \\
\hline$\langle T-\mathrm{O}\rangle$ & 1.620 & 1.620 \\
\hline $\mathrm{H} 3-\mathrm{O} 3$ & $0.85(2)$ & $0.80(4)$ \\
\hline
\end{tabular}

Notes: Standard uncertainty in parentheses. Superscript letters: $\mathrm{A}=(\mathrm{y}-$ $\mathrm{x}, \mathrm{y}, \mathrm{z}) ; \mathrm{B}=(\mathrm{y}-\mathrm{x},-\mathrm{x}, \mathrm{z}) ; \mathrm{C}=(\mathrm{x}, \mathrm{x}-\mathrm{y}, \mathrm{z}) ; \mathrm{D}=(\mathrm{y}-\mathrm{x}+1 / 3,-\mathrm{x}+2 / 3$, $z+2 / 3) ; E=(-y+2 / 3, x-y+1 / 3, z+1 / 3) ; F=(-y, x-y, z)$. Transformations relate coordinates to those of Table 3 .

* Positioned in adjacent unit cell. 
TABLE 7. Cation site populations (apfu), mean atomic numbers and mean bond lengths $(\AA)$ for oxy-chromium-dravite (T89104) and oxy-dravite (PR108)

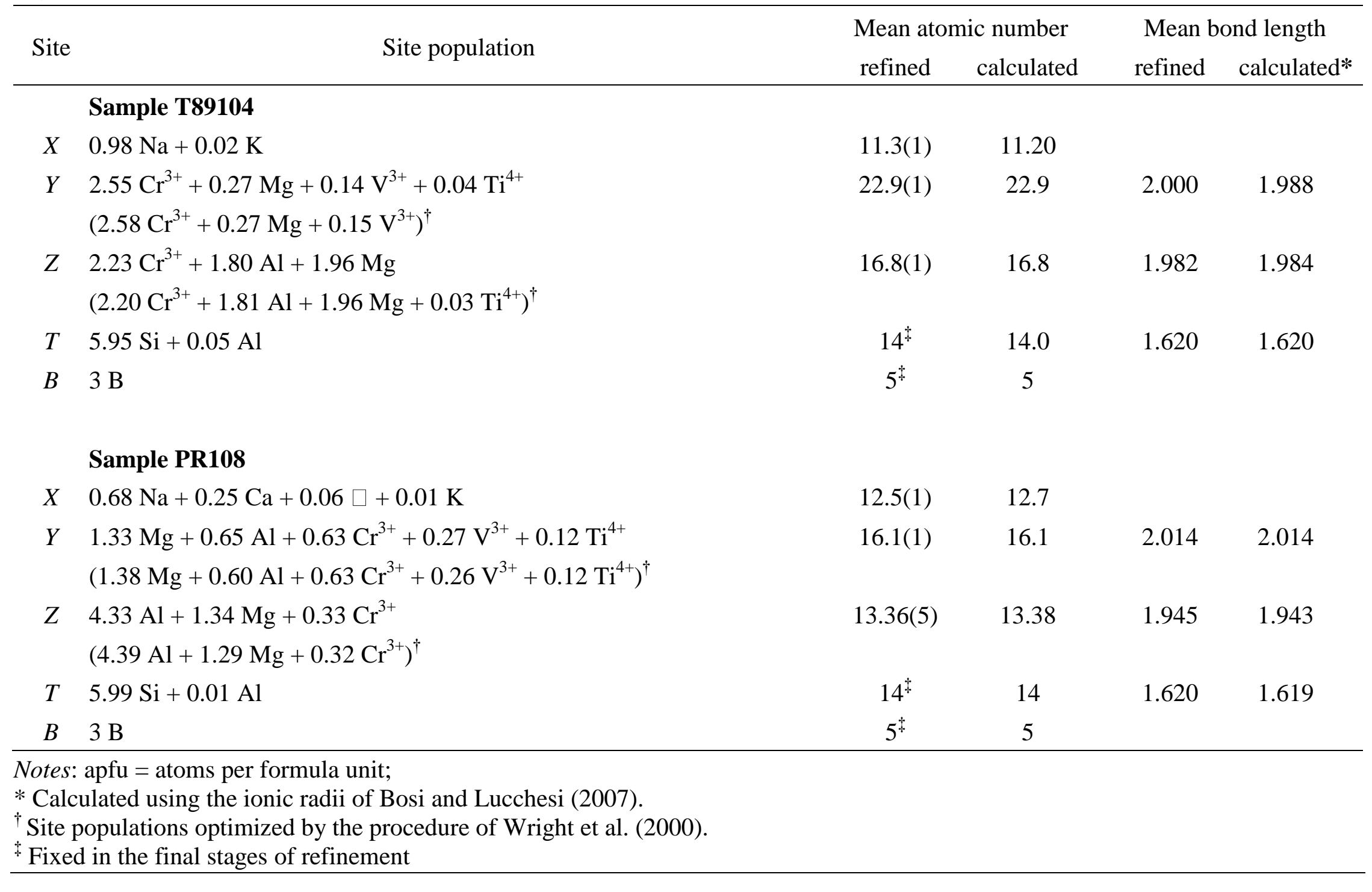


TABLE 8. Structural formulae of six oxy-tourmalines used in this study

\begin{tabular}{|c|c|c|}
\hline Sample & Structural formula & Reference \\
\hline $\begin{array}{c}\text { PR108 } \\
\text { (oxy-dravite) }\end{array}$ & 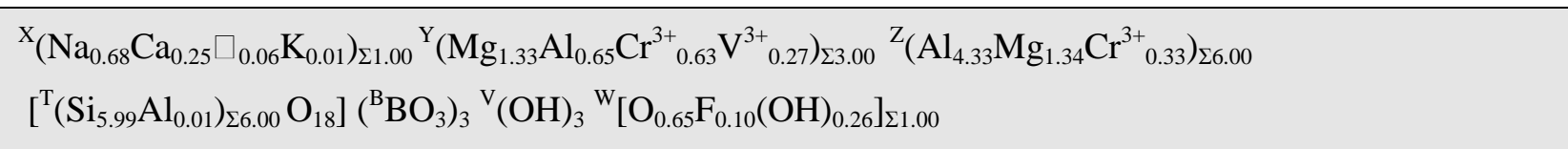 & [1] \\
\hline $\begin{array}{l}\text { PR107 } \\
\text { (chromo-alumino-povondraite) }\end{array}$ & $\begin{array}{l}\mathrm{X}^{\mathrm{X}}\left(\mathrm{Na}_{0.76} \mathrm{Ca}_{0.19} \square_{0.03} \mathrm{~K}_{0.02}\right)_{\Sigma 1.00}{ }^{\mathrm{Y}}\left(\mathrm{Cr}^{3+}{ }_{1.94} \mathrm{Mg}_{0.93} \mathrm{Al}_{0.07} \mathrm{Ti}^{4+}{ }_{0.06}\right)_{\Sigma 3.00}{ }^{\mathrm{Z}}\left(\mathrm{Al}_{3.74} \mathrm{Mg}_{1.43} \mathrm{Fe}^{3+}{ }_{0.32} \mathrm{~V}^{3+}{ }_{0.19} \mathrm{Cr}^{3+}{ }_{0.16} \mathrm{Fe}^{2+}{ }_{0.15}\right)_{\Sigma 6.00} \\
{\left[{ }^{\mathrm{T}}\left(\mathrm{Si}_{5.99} \mathrm{Al}_{0.01}\right)_{\Sigma 6.00} \mathrm{O}_{18}\right]\left({ }^{\mathrm{B}} \mathrm{BO}_{3}\right)_{3}{ }^{\mathrm{V}}(\mathrm{OH})_{3}{ }^{\mathrm{W}}\left[\mathrm{O}_{0.69} \mathrm{~F}_{0.23}(\mathrm{OH})_{0.08}\right]_{\Sigma 1.00}}\end{array}$ & [2] \\
\hline $\begin{array}{l}\text { Tm1p43e } \\
\text { (chromo-alumino-povondraite) }\end{array}$ & $\begin{array}{l}{ }^{\mathrm{x}}\left(\mathrm{Na}_{0.89} \mathrm{Ca}_{0.03} \square_{0.06} \mathrm{~K}_{0.02}\right)_{\Sigma 1.00}{ }^{\mathrm{Y}}\left(\mathrm{Cr}^{3+}{ }_{2.17} \mathrm{Mg}_{0.65} \mathrm{Al}_{0.10} \mathrm{~V}^{3+}{ }_{0.06} \mathrm{Zn}_{0.02}\right)_{\Sigma 3.00}{ }^{\mathrm{Z}}\left(\mathrm{Al}_{3.25} \mathrm{Mg}_{1.52} \mathrm{Cr}^{3+}{ }_{0.97} \mathrm{~V}^{3+}{ }_{0.22} \mathrm{Fe}^{2+}{ }_{0.04}\right)_{\Sigma 6.00} \\
{\left[{ }^{\mathrm{T}}\left(\mathrm{Si}_{5.99} \mathrm{Al}_{0.01}\right)_{\Sigma 6.00} \mathrm{O}_{18}\right]\left({ }^{\mathrm{B}} \mathrm{BO}_{3}\right)_{3}{ }^{\mathrm{V}}(\mathrm{OH})_{3}{ }^{\mathrm{W}}\left[\mathrm{O}_{0.71} \mathrm{~F}_{0.26}(\mathrm{OH})_{0.03}\right]_{\Sigma 1.00}}\end{array}$ & [4] \\
\hline $\begin{array}{l}\text { PR85v } \\
\text { (chromo-alumino-povondraite) }\end{array}$ & 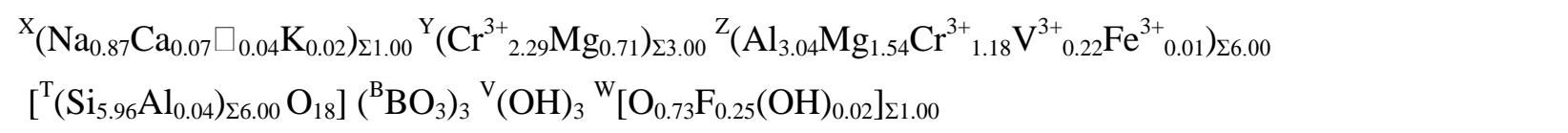 & [3] \\
\hline $\begin{array}{l}\text { Tmt6b } \\
\text { (chromo-alumino-povondraite) }\end{array}$ & 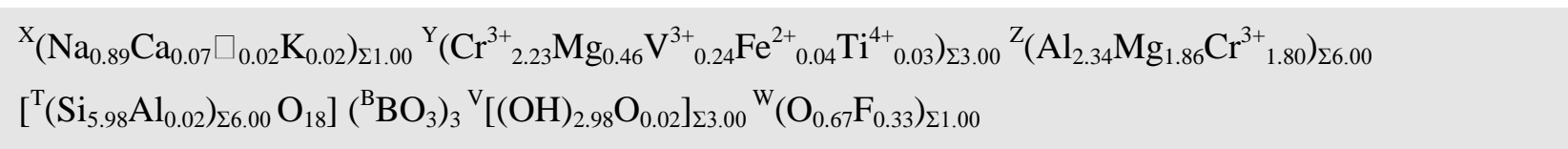 & [4] \\
\hline $\begin{array}{l}\text { T89104 } \\
\text { (oxy-chromium-dravite) }\end{array}$ & $\begin{array}{l}\mathrm{X}\left(\mathrm{Na}_{0.98} \mathrm{~K}_{0.02}\right)_{\Sigma 1.00}{ }^{\mathrm{Y}}\left(\mathrm{Cr}^{3+}{ }_{2.55} \mathrm{~V}^{3+}{ }_{0.14} \mathrm{Mg}_{0.27} \mathrm{Ti}^{4+}{ }_{0.04}\right)_{\Sigma 3.00}{ }^{\mathrm{Z}}\left(\mathrm{Cr}^{3+}{ }_{2.23} \mathrm{Al}_{1.80} \mathrm{Mg}_{1.96}\right)_{\Sigma 6.00} \\
{\left[{ }^{\mathrm{T}}\left(\mathrm{Si}_{5.95} \mathrm{Al}_{0.05}\right)_{\Sigma 6.00} \mathrm{O}_{18}\right]\left({ }^{\mathrm{B}} \mathrm{BO}_{3}\right)_{3}{ }^{\mathrm{V}}\left[(\mathrm{OH})_{2.92} \mathrm{O}_{0.08}\right]_{\Sigma 3.00}{ }^{\mathrm{W}}\left(\mathrm{O}_{0.68} \mathrm{~F}_{0.32}\right)_{\Sigma 1.00}}\end{array}$ & [1] \\
\hline
\end{tabular}

[1] = present study, [2] = Bosi et al. (2013), [3] = Reznitskii et al. (2014), [4] = Bosi et al. (2004) 
Table 9 Sample thicknesses and peak area intensities for infrared- and Raman-bands

\begin{tabular}{|c|c|c|c|c|c|c|}
\hline Sample & PR108 & PR107 & PR85v & Tm1p43e & Tmt6b & T89104 \\
\hline Thickness $(\mu \mathrm{m})$ & 48 & 47 & 26 & 45 & 50 & 41 \\
\hline \multicolumn{7}{|c|}{ Infrared-bands } \\
\hline PAI (\%) 3519 & 29 & 56 & 73 & 71 & 79 & 90 \\
\hline PAI (\%) 3565 & 71 & 44 & 27 & 29 & 21 & 10 \\
\hline \multicolumn{7}{|c|}{ Raman-bands } \\
\hline PAI (\%) 3520 & - & $60^{\mathrm{a}}$ & 62 & 60 & - & 82 \\
\hline PAI (\%) 3556 & - & $40^{\mathrm{a}}$ & 38 & 40 & - & 18 \\
\hline
\end{tabular}

$\mathrm{PAI}=$ Fitted relative peak area intensity for the vibrational-bands

${ }^{\mathrm{a}}$ Large fitting error ( 15\%) 
TABLE 1. Methodologies used to characterized the six oxy-tourmaline samples used in this study and references

\begin{tabular}{|c|c|c|c|c|c|c|}
\hline Sample & EMP & SREF & MS & OAS & IR & RAMAN \\
\hline PR108 & This study & This study & - & - & This study & - \\
\hline PR107 & Bosi et al. (2013) & Bosi et al. (2013) & Bosi et al. (2013) & Bosi et al. (2013) & Bosi et al. (2013) & This study \\
\hline PR85v & Reznitskii et al. (2014) & Reznitskii et al. (2014) & - & Reznitskii et al. (2014) & Reznitskii et al. (2014) & This study \\
\hline Tm1p43e & Bosi et al. (2004) & Bosi et al. (2004) & - & - & This study & This study \\
\hline Tmt6b & Bosi et al. (2004) & Bosi et al. (2004) & - & - & This study & - \\
\hline T89104 & This study & This study & - & - & This study & This study \\
\hline
\end{tabular}

EMP = electron microprobe; SREF = structural refinement; MS = Mössbauer spectroscopy; OAS = optical absorption spectroscopy; IR = infrared spectroscopy; RAMAN = Raman spectroscopy 
TABLE 2. Single-crystal X-ray diffraction data details for oxy-chromium-dravite (T89104) and oxy-dravite (PR108)

\begin{tabular}{lll}
\hline Sample & T89104 & PR108 \\
\hline Crystal size $(\mathrm{mm})$ & $0.11 \times 0.18 \times 0.20$ & $0.15 \times 0.17 \times 0.25$ \\
$a(\AA)$ & $16.0572(3)$ & $15.9710(2)$ \\
$c(\AA)$ & $7.3328(1)$ & $7.2471(1)$ \\
$V\left(\AA^{3}\right)$ & $1637.34(5)$ & $1600.88(5)$ \\
Range for data collection, $2 \theta\left(^{\circ}\right)$ & $5-73$ & $5-65$ \\
Reciprocal space range $h k l$ & $-26 \leq h \leq 24$ & $-24 \leq h \leq 22$ \\
& $-23 \leq k \leq 26$ & $-24 \leq k \leq 20$ \\
& $-6 \leq l \leq 12$ & $-9 \leq l \leq 10$ \\
Total number of frames & 1469 & 3265 \\
Set of measured reflections & 5024 & 6874 \\
Unique reflections, $R_{\text {int }}(\%)$ & $1416,1.46$ & $1354,1.86$ \\
Redundancy & 5 & 10 \\
Absorption correction method & SADABS & SADABS \\
Refinement method & Full-matrix last-squares on $F^{2}$ & Full-matrix last-squares on $F^{2}$ \\
Structural refinement program & SHELXL-2013 & SHELXL-2013 \\
Extinction coefficient & $0.00060(9)$ & $0.0003(2)$ \\
Flack parameter & $0.073(19)$ & $0.07(4)$ \\
$w R 2(\%)$ & 2.80 & 4.02 \\
$R 1(\%)$ all data & 1.29 & 1.65 \\
$R 1(\%)$ for $I>2 \sigma(I)$ & 1.28 & 1.61 \\
GooF & 1.099 & 1.083 \\
Largest diff. peak and hole $\left( \pm \mathrm{e}^{-} / \AA^{3}\right)$ & 0.42 and -0.29 & 0.34 and -0.30 \\
\hline
\end{tabular}

Notes: $R_{\text {int }}=$ merging residual value; $R 1=$ discrepancy index, calculated from $F$-data; $w R 2=$ weighted discrepancy index, calculated from $F^{2}$-data; GooF = goodness of fit; Diff. Peaks = maximum and minimum residual electron density.

Radiation, $\mathrm{Mo} K \alpha=0.71073 \AA$. Data collection temperature $=293 \mathrm{~K}$. Space group $R 3 m ; Z=3$. 
TABLE 6. Chemical composition for oxy-chromium-dravite (T89104) and oxy-dravite (PR108)

\begin{tabular}{|c|c|c|}
\hline Sample & T89104 & PR108 \\
\hline $\mathrm{SiO}_{2} \mathrm{wt} \%$ & $32.61(9)$ & $36.25(33)$ \\
\hline $\mathrm{TiO}_{2}$ & $0.28(5)$ & $0.95(1)$ \\
\hline $\mathrm{B}_{2} \mathrm{O}_{3}$ & $9.53 *$ & $10.51 *$ \\
\hline $\mathrm{Al}_{2} \mathrm{O}_{3}$ & $8.62(33)$ & $25.51(55)$ \\
\hline $\mathrm{Cr}_{2} \mathrm{O}_{3}$ & $33.16(58)$ & $7.42(52)$ \\
\hline $\mathrm{V}_{2} \mathrm{O}_{3}$ & $0.98(15)$ & $2.09(3)$ \\
\hline $\mathrm{MgO}$ & $8.20(12)$ & $10.83(15)$ \\
\hline $\mathrm{CaO}$ & bdl & $1.43(11)$ \\
\hline $\mathrm{Na}_{2} \mathrm{O}$ & $2.76(6)$ & $2.11(4)$ \\
\hline $\mathrm{K}_{2} \mathrm{O}$ & $0.10(2)$ & $0.05(1)$ \\
\hline $\mathrm{F}$ & $0.56(5)$ & $0.20(9)$ \\
\hline $\mathrm{H}_{2} \mathrm{O}$ & $2.40 *$ & $2.95 *$ \\
\hline$-\mathrm{O} \equiv \mathrm{F}$ & -0.24 & -0.08 \\
\hline Total & 99.96 & 100.62 \\
\hline
\end{tabular}

Atomic proportions normalized to 31 anions

\begin{tabular}{lcc}
$\mathrm{Si}$ apfu & 5.95 & 5.99 \\
$\mathrm{Ti}^{4+}$ & 0.04 & 0.12 \\
$\mathrm{~B}$ & 3.00 & 3.00 \\
$\mathrm{Al}$ & 1.85 & 4.97 \\
$\mathrm{Cr}^{3+}$ & 4.78 & 0.97 \\
$\mathrm{~V}^{3+}$ & 0.14 & 0.28 \\
$\mathrm{Mg}$ & 2.23 & 2.67 \\
$\mathrm{Ca}$ & - & 0.25 \\
$\mathrm{Na}$ & 0.98 & 0.68 \\
$\mathrm{~K}$ & 0.02 & 0.01 \\
$\mathrm{~F}$ & 0.32 & 0.10 \\
$\mathrm{OH}$ & 2.92 & 3.26 \\
\hline
\end{tabular}

* Calculated by stoichiometry.

Notes: Errors for oxides are standard deviations (in brackets) of 7 spot analyses; apfu = atoms per formula unit. 
TABLE 3. Fractional atom coordinates and site occupancy for oxy-chromium-dravite (T89104) and oxy-dravite (PR108)

\begin{tabular}{|c|c|c|c|c|c|c|c|c|}
\hline \multirow{2}{*}{$\frac{\text { Sample }}{\text { Site }}$} & \multicolumn{3}{|c|}{ T89104 } & \multirow[b]{2}{*}{ Site occupancy } & \multicolumn{3}{|c|}{ PR108 } & \multirow[b]{2}{*}{ Site occupancy } \\
\hline & $x$ & $y$ & $z$ & & $x$ & $y$ & $z$ & \\
\hline$X$ & 0 & 0 & $0.22571(23)$ & $\mathrm{Na}_{1.030(8)}$ & 0 & 0 & $0.22857(24)$ & $\mathrm{Na}_{1.131(10)}$ \\
\hline$Y$ & $0.12333(2)$ & $0.06166(2)$ & $0.63792(7)$ & $\mathrm{Cr}_{0.905(5)} \mathrm{Mg}_{0.095(5)}$ & $0.12371(4)$ & $0.06185(2)$ & $0.63655(10)$ & $\mathrm{Cr}_{0.340(6)} \mathrm{Mg}_{0.660(6)}$ \\
\hline$Z$ & $0.29770(2)$ & $0.26173(2)$ & $0.60851(6)$ & $\mathrm{Cr}_{0.396(3)} \mathrm{Mg}_{0.604(3)}$ & $0.29807(4)$ & $0.26189(4)$ & $0.61118(10)$ & $\mathrm{Al}_{1.029(4)}$ \\
\hline$B$ & $0.10971(7)$ & $0.21941(15)$ & $0.45434(26)$ & $\mathrm{B}_{1.00}$ & $0.10994(10)$ & $0.21987(20)$ & $0.45380(38)$ & $\mathrm{B}_{1.00}$ \\
\hline$T$ & $0.18992(2)$ & $0.18822(2)$ & 0 & $\mathrm{Si}_{1.00}$ & $0.19129(3)$ & $0.18953(3)$ & 0 & $\mathrm{Si}_{1.00}$ \\
\hline $\mathrm{O} 1$ & 0 & 0 & $0.76520(29)$ & $\mathrm{O}_{1.00}$ & 0 & 0 & $0.76915(44)$ & $\mathrm{O}_{1.00}$ \\
\hline $\mathrm{O} 2$ & $0.06026(5)$ & $0.12052(9)$ & $0.48998(18)$ & $\mathrm{O}_{1.00}$ & $0.06066(7)$ & $0.12133(13)$ & $0.48483(28)$ & $\mathrm{O}_{1.00}$ \\
\hline $\mathrm{O} 3$ & $0.25584(10)$ & $0.12792(5)$ & $0.50928(19)$ & $\mathrm{O}_{1.00}$ & $0.26110(14)$ & $0.13055(7)$ & $0.51161(28)$ & $\mathrm{O}_{1.00}$ \\
\hline $\mathrm{O} 4$ & $0.09255(5)$ & $0.18509(11)$ & $0.07200(18)$ & $\mathrm{O}_{1.00}$ & $0.09265(7)$ & $0.18530(15)$ & $0.07174(28)$ & $\mathrm{O}_{1.00}$ \\
\hline O5 & $0.18281(8)$ & $0.09141(4)$ & $0.09112(14)$ & $\mathrm{O}_{1.00}$ & $0.18259(14)$ & $0.09130(7)$ & $0.09175(27)$ & $\mathrm{O}_{1.00}$ \\
\hline O6 & $0.19124(7)$ & $0.18200(7)$ & $0.78035(13)$ & $\mathrm{O}_{1.00}$ & $0.19404(9)$ & $0.18448(9)$ & $0.77871(20)$ & $\mathrm{O}_{1.00}$ \\
\hline $\mathrm{O} 7$ & $0.28300(7)$ & $0.28267(6)$ & $0.07274(13)$ & $\mathrm{O}_{1.00}$ & $0.28445(9)$ & $0.28404(8)$ & $0.07748(19)$ & $\mathrm{O}_{1.00}$ \\
\hline $\mathrm{O} 8$ & $0.20715(7)$ & $0.26764(7)$ & $0.43738(15)$ & $\mathrm{O}_{1.00}$ & $0.20886(9)$ & $0.26956(9)$ & $0.44006(21)$ & $\mathrm{O}_{1.00}$ \\
\hline $\mathrm{H} 3$ & $0.2555(19)$ & $0.1278(9)$ & $0.393(3)$ & $\mathrm{H}_{1.00}$ & $0.2546(25)$ & $0.1273(12)$ & $0.386(3)$ & $\mathrm{H}_{1.00}$ \\
\hline
\end{tabular}


TABLE 4. Displacement parameters $\left(\AA^{2}\right)$ for oxy-chromium-dravite (T89104) and oxy-dravite (PR108)

\begin{tabular}{|c|c|c|c|c|c|c|c|}
\hline \multirow[b]{2}{*}{ Site } & $U^{11}$ & $U^{22}$ & $U^{33}$ & $U^{23}$ & $U^{13}$ & $U^{12}$ & $U_{\text {eq }} / U_{\text {iso }} *$ \\
\hline & & & & \multicolumn{4}{|l|}{ T89104 } \\
\hline$X$ & $0.0236(6)$ & $0.0236(6)$ & $0.0198(8)$ & 0 & 0 & $0.0118(3)$ & $0.0223(5)$ \\
\hline$Y$ & $0.00439(13)$ & $0.00433(10)$ & $0.00659(11)$ & $-0.00017(4)$ & $-0.00035(8)$ & $0.00220(6)$ & $0.00510(8)$ \\
\hline$Z$ & $0.00439(13)$ & $0.00479(13)$ & $0.00581(11)$ & $0.00044(8)$ & $-0.00004(8)$ & $0.00232(10)$ & $0.00498(8)$ \\
\hline$B$ & $0.0062(5)$ & $0.0071(7)$ & $0.0092(7)$ & $0.0010(6)$ & $0.0005(3)$ & $0.0035(4)$ & $0.0074(3)$ \\
\hline$T$ & $0.00502(15)$ & $0.00459(14)$ & $0.00661(13)$ & $-0.00037(10)$ & $-0.00031(11)$ & $0.00229(11)$ & $0.00546(8)$ \\
\hline $\mathrm{O} 1$ & $0.0058(5)$ & $0.0058(5)$ & $0.0077(8)$ & 0 & 0 & $0.0029(3)$ & $0.0064(4)$ \\
\hline $\mathrm{O} 2$ & $0.0054(4)$ & $0.0051(5)$ & $0.0081(5)$ & $0.0011(4)$ & $0.00053(19)$ & $0.0025(2)$ & $0.0062(2)$ \\
\hline $\mathrm{O} 3$ & $0.0102(6)$ & $0.0106(4)$ & $0.0071(5)$ & $0.0004(2)$ & $0.0008(4)$ & $0.0051(3)$ & $0.0093(2)$ \\
\hline $\mathrm{O} 4$ & $0.0079(4)$ & $0.0166(7)$ & $0.0094(5)$ & $-0.0008(4)$ & $-0.0004(2)$ & $0.0083(3)$ & $0.0103(2)$ \\
\hline O5 & $0.0144(6)$ & $0.0069(4)$ & $0.0085(5)$ & $0.0006(2)$ & $0.0013(4)$ & $0.0072(3)$ & $0.0091(2)$ \\
\hline O6 & $0.0091(4)$ & $0.0064(4)$ & $0.0059(3)$ & $-0.0007(3)$ & $-0.0003(3)$ & $0.0038(3)$ & $0.00717(16)$ \\
\hline $\mathrm{O} 7$ & $0.0077(4)$ & $0.0061(4)$ & $0.0099(3)$ & $-0.0013(3)$ & $-0.0023(3)$ & $0.0007(3)$ & $0.00910(16)$ \\
\hline $\mathrm{O} 8$ & $0.0048(4)$ & $0.0084(4)$ & $0.0171(4)$ & $0.0030(3)$ & $0.0011(3)$ & $0.0029(3)$ & $0.01030(17)$ \\
\hline \multirow[t]{2}{*}{$\mathrm{H} 3$} & & & & & & & $0.011 *$ \\
\hline & & & & \multicolumn{4}{|l|}{ PR108 } \\
\hline$X$ & $0.0135(6)$ & $0.0135(6)$ & $0.0148(9)$ & 0 & 0 & $0.0067(3)$ & $0.0139(5)$ \\
\hline$Y$ & $0.0058(3)$ & $0.0045(2)$ & $0.0080(3)$ & $-0.00106(9)$ & $-0.00212(18)$ & $0.00288(14)$ & $0.00596(19)$ \\
\hline$Z$ & $0.0062(2)$ & $0.0064(2)$ & $0.0067(2)$ & $0.00037(17)$ & $-0.00018(17)$ & $0.00298(18)$ & $0.00649(14)$ \\
\hline$B$ & $0.0074(8)$ & $0.0080(10)$ & $0.0077(11)$ & $0.0000(8)$ & $0.0000(4)$ & $0.0040(5)$ & $0.0077(4)$ \\
\hline$T$ & $0.0058(2)$ & $0.0055(2)$ & $0.0071(2)$ & $-0.00073(15)$ & $-0.00072(16)$ & $0.00264(16)$ & $0.00622(12)$ \\
\hline $\mathrm{O} 1$ & $0.0114(8)$ & $0.0114(8)$ & $0.0102(14)$ & 0 & 0 & $0.0057(4)$ & $0.0110(6)$ \\
\hline $\mathrm{O} 2$ & $0.0107(6)$ & $0.0065(7)$ & $0.0144(9)$ & $0.0010(6)$ & $0.0005(3)$ & $0.0033(4)$ & $0.0110(4)$ \\
\hline $\mathrm{O} 3$ & $0.0206(9)$ & $0.0148(6)$ & $0.0066(8)$ & $0.0005(3)$ & $0.0010(7)$ & $0.0103(5)$ & $0.0134(4)$ \\
\hline $\mathrm{O} 4$ & $0.0092(5)$ & $0.0187(9)$ & $0.0118(8)$ & $-0.0009(7)$ & $-0.0004(3)$ & $0.0094(5)$ & $0.0122(3)$ \\
\hline O5 & $0.0163(9)$ & $0.0083(5)$ & $0.0122(8)$ & $0.0012(3)$ & $0.0024(7)$ & $0.0082(4)$ & $0.0114(3)$ \\
\hline O6 & $0.0120(6)$ & $0.0104(5)$ & $0.0074(5)$ & $-0.0018(4)$ & $-0.0014(4)$ & $0.0061(4)$ & $0.0097(2)$ \\
\hline $\mathrm{O} 7$ & $0.0095(5)$ & $0.0080(5)$ & $0.0113(6)$ & $-0.0009(4)$ & $-0.0028(4)$ & $0.0019(4)$ & $0.0107(3)$ \\
\hline $\mathrm{O} 8$ & $0.0064(5)$ & $0.0099(6)$ & $0.0188(6)$ & $0.0023(4)$ & $0.0008(5)$ & $0.0039(5)$ & $0.0118(3)$ \\
\hline $\mathrm{H} 3$ & & & & & & & $0.016^{*}$ \\
\hline
\end{tabular}

Notes: Equivalent $\left(U_{\text {eq }}\right)$ and isotropic $\left(U_{\text {iso }}\right)$ displacement parameters; H-atom was constrained to have a $U_{\text {iso }} 1.2$ times the $U_{\text {eq }}$ value of the $\mathrm{O} 3$ oxygen. 
TABLE 5. Selected bond distances $(\AA)$ for oxy-chromiumdravite (T89104) and oxy-dravite (PR108)

\begin{tabular}{|c|c|c|}
\hline Sample & T89104 & PR108 \\
\hline$X-\mathrm{O} 2^{\mathrm{B}, \mathrm{F}}(\times 3)$ & $2.562(2)$ & $2.503(2)$ \\
\hline$X-\mathrm{O} 5^{\mathrm{B}, \mathrm{F}}(\times 3)$ & $2.727(2)$ & $2.713(2)$ \\
\hline$X-\mathrm{O} 4^{\mathrm{B}, \mathrm{F}}(\times 3)$ & $2.810(2)$ & $2.804(2)$ \\
\hline$\langle X-\mathrm{O}\rangle$ & 2.700 & 2.673 \\
\hline$Y-\mathrm{O} 1$ & $1.953(1)$ & $1.962(2)$ \\
\hline$Y-\mathrm{O6}^{\mathrm{C}}(\times 2)$ & $1.977(1)$ & $1.990(1)$ \\
\hline$Y-\mathrm{O} 2^{\mathrm{B}}(\times 2)$ & $2.0131(9)$ & $2.020(1)$ \\
\hline$Y-\mathrm{O} 3$ & $2.070(1)$ & $2.105(2)$ \\
\hline$\langle Y-\mathrm{O}\rangle$ & 2.000 & 2.015 \\
\hline$Z-O 8^{\mathrm{E}}$ & $1.950(1)$ & $1.909(1)$ \\
\hline $\mathrm{Z}-\mathrm{O} 7^{\mathrm{E}}$ & $1.964(1)$ & $1.923(1)$ \\
\hline Z-O8 & $1.959(1)$ & $1.938(1)$ \\
\hline Z-O6 & $1.990(1)$ & $1.926(1)$ \\
\hline $\mathrm{Z}-\mathrm{O} 7^{\mathrm{D}}$ & $1.992(1)$ & $1.965(1)$ \\
\hline $\mathrm{Z}-\mathrm{O} 3$ & $2.0380(7)$ & $2.008(1)$ \\
\hline$\langle\mathrm{Z}-\mathrm{O}\rangle$ & 1.982 & 1.945 \\
\hline$B-\mathrm{O}^{\mathrm{A}}(\times 2)$ & $1.361(1)$ & $1.372(2)$ \\
\hline$B-\mathrm{O} 2$ & $1.400(2)$ & $1.381(3)$ \\
\hline$\langle B-\mathrm{O}\rangle$ & 1.374 & 1.375 \\
\hline$T-\mathrm{O} 7$ & $1.5974(9)$ & $1.601(1)$ \\
\hline$T^{*-\mathrm{O} 6}$ & $1.615(1)$ & $1.608(2)$ \\
\hline$T-\mathrm{O} 4$ & $1.6271(5)$ & $1.6279(8)$ \\
\hline$T-\mathrm{O5}$ & $1.6426(6)$ & $1.6447(9)$ \\
\hline$\langle T-\mathrm{O}\rangle$ & 1.621 & 1.620 \\
\hline $\mathrm{H} 3-\mathrm{O} 3$ & $0.93(2)$ & $0.92(2)$ \\
\hline O3-O5 & 3.230 & 3.231 \\
\hline
\end{tabular}

Notes: Standard uncertainty in parentheses. Superscript letters: $\mathrm{A}=(\mathrm{y}-$ $\mathrm{x}, \mathrm{y}, \mathrm{z}) ; \mathrm{B}=(\mathrm{y}-\mathrm{x},-\mathrm{x}, \mathrm{z}) ; \mathrm{C}=(\mathrm{x}, \mathrm{x}-\mathrm{y}, \mathrm{z}) ; \mathrm{D}=(\mathrm{y}-\mathrm{x}+1 / 3,-\mathrm{x}+2 / 3$, $z+2 / 3) ; E=(-y+2 / 3, x-y+1 / 3, z+1 / 3) ; F=(-y, x-y, z)$. Transformations relate coordinates to those of Table 3 .

* Positioned in adjacent unit cell. 
TABLE 7. Cation site populations (apfu), mean atomic numbers and mean bond lengths $(\AA)$ for oxy-chromium-dravite (T89104) and oxy-dravite (PR108)

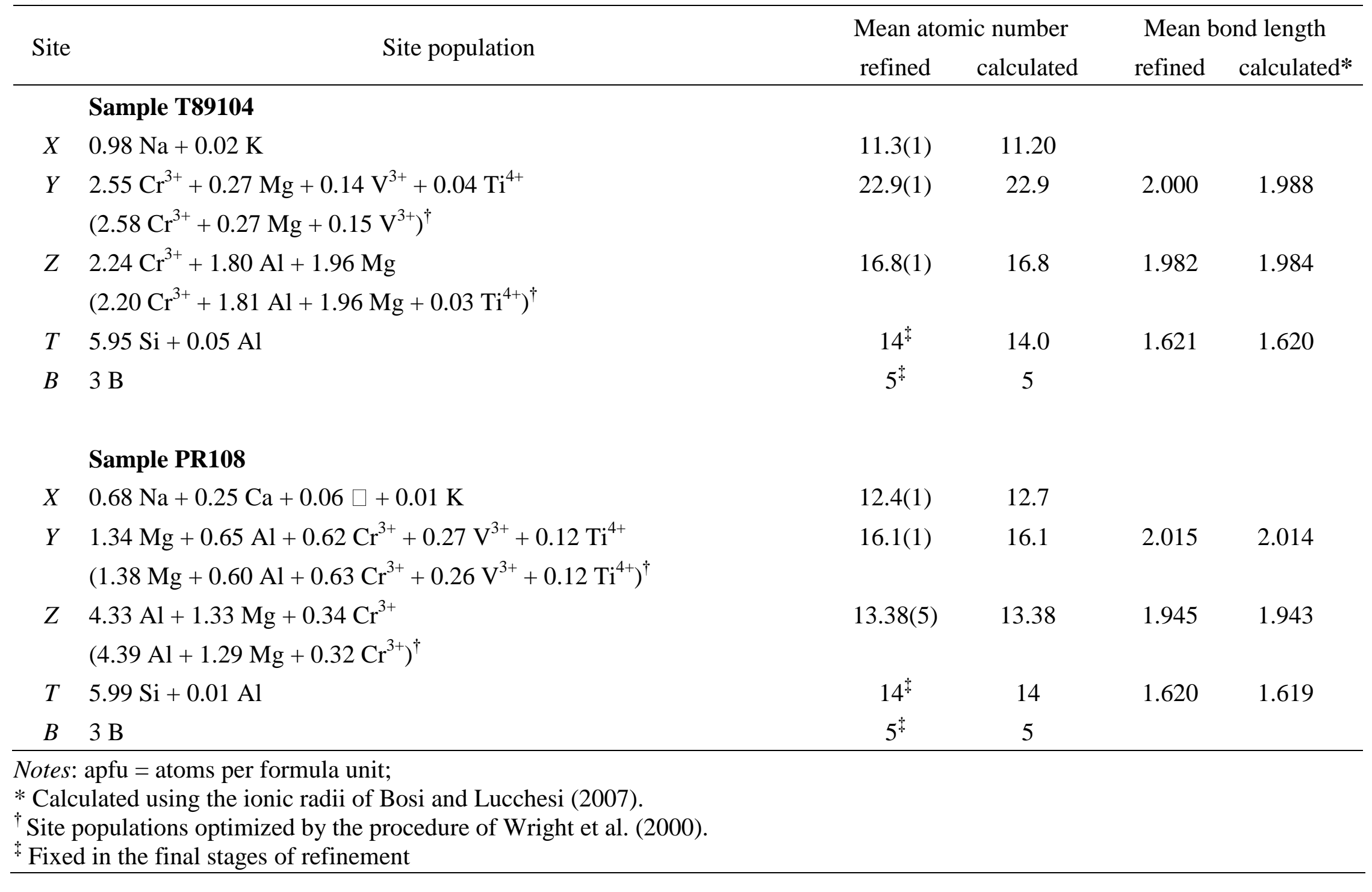


TABLE 8. Structural formulae of six oxy-tourmalines used in this study

\begin{tabular}{|c|c|c|}
\hline Sample & Structural formula & Reference \\
\hline $\begin{array}{c}\text { PR108 } \\
\text { (oxy-dravite) }\end{array}$ & $\begin{array}{l}{ }^{\mathrm{X}}\left(\mathrm{Na}_{0.68} \mathrm{Ca}_{0.25} \square_{0.06} \mathrm{~K}_{0.01}\right)_{\Sigma 1.00}{ }^{\mathrm{Y}}\left(\mathrm{Mg}_{1.34} \mathrm{Al}_{0.65} \mathrm{Cr}^{3+}{ }_{0.62} \mathrm{~V}^{3+}{ }_{0.27} \mathrm{Ti}^{4+}{ }_{0.12}\right)_{\Sigma 3.00}{ }^{\mathrm{Z}}\left(\mathrm{Al}_{4.33} \mathrm{Mg}_{1.33} \mathrm{Cr}^{3+}{ }_{0.34}\right)_{\Sigma 6.00} \\
{\left[{ }^{\mathrm{T}}\left(\mathrm{Si}_{5.99} \mathrm{Al}_{0.01}\right)_{\Sigma 6.00} \mathrm{O}_{18}\right]\left({ }^{\mathrm{B}} \mathrm{BO}_{3}\right)_{3}{ }^{\mathrm{V}}(\mathrm{OH})_{3}{ }^{\mathrm{W}}\left[\mathrm{O}_{0.65} \mathrm{~F}_{0.10}(\mathrm{OH})_{0.26}\right]_{\Sigma 1.00}}\end{array}$ & [1] \\
\hline $\begin{array}{l}\text { PR107 } \\
\text { (chromo-alumino-povondraite) }\end{array}$ & $\begin{array}{l}{ }^{\mathrm{X}}\left(\mathrm{Na}_{0.76} \mathrm{Ca}_{0.19} \square_{0.03} \mathrm{~K}_{0.02}\right)_{\Sigma 1.00}{ }^{\mathrm{Y}}\left(\mathrm{Cr}^{3+}{ }_{1.94} \mathrm{Mg}_{0.93} \mathrm{Al}_{0.07} \mathrm{Ti}^{4+}{ }_{0.06}\right)_{\Sigma 3.00}{ }^{\mathrm{Z}}\left(\mathrm{Al}_{3.74} \mathrm{Mg}_{1.43} \mathrm{Fe}^{3+}{ }_{0.32} \mathrm{~V}^{3+}{ }_{0.19} \mathrm{Cr}^{3+}{ }_{0.16} \mathrm{Fe}^{2+}{ }_{0.15}\right)_{\Sigma 6.00} \\
\left.{ }^{\mathrm{T}}\left(\mathrm{Si}_{5.99} \mathrm{Al}_{0.01}\right)_{\Sigma 6.00} \mathrm{O}_{18}\right]\left({ }^{\mathrm{B}} \mathrm{BO}_{3}\right)_{3}{ }^{\mathrm{V}}(\mathrm{OH})_{3}{ }^{\mathrm{W}}\left[\mathrm{O}_{0.69} \mathrm{~F}_{0.23}(\mathrm{OH})_{0.08}\right]_{\Sigma 1.00}\end{array}$ & [2] \\
\hline $\begin{array}{l}\operatorname{Tm} 1 \mathrm{p} 43 \mathrm{e} \\
\text { (chromo-alumino-povondraite) }\end{array}$ & 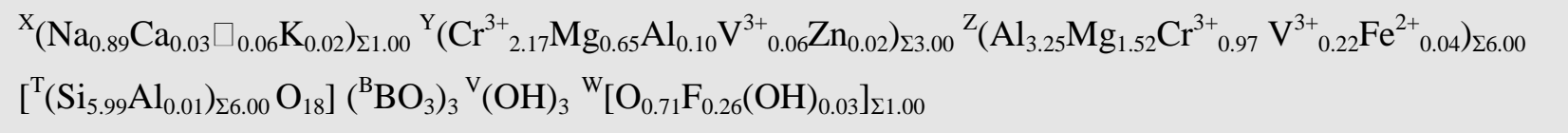 & {$[4]$} \\
\hline $\begin{array}{l}\text { PR85v } \\
\text { (chromo-alumino-povondraite) }\end{array}$ & $\begin{array}{l}{ }^{\mathrm{X}}\left(\mathrm{Na}_{0.87} \mathrm{Ca}_{0.07} \square_{0.04} \mathrm{~K}_{0.02}\right)_{\Sigma 1.00}{ }^{\mathrm{Y}}\left(\mathrm{Cr}^{3+}{ }_{2.29} \mathrm{Mg}_{0.71}\right)_{\Sigma 3.00}{ }^{\mathrm{Z}}\left(\mathrm{Al}_{3.04} \mathrm{Mg}_{1.54} \mathrm{Cr}^{3+}{ }_{1.18} \mathrm{~V}^{3+}{ }_{0.22} \mathrm{Fe}^{3+}{ }_{0.01}\right)_{\Sigma 6.00} \\
{\left[{ }^{\mathrm{T}}\left(\mathrm{Si}_{5.96} \mathrm{Al}_{0.04}\right)_{\Sigma 6.00} \mathrm{O}_{18}\right]\left({ }^{\mathrm{B}} \mathrm{BO}_{3}\right)_{3}{ }^{\mathrm{V}}(\mathrm{OH})_{3}{ }^{\mathrm{W}}\left[\mathrm{O}_{0.73} \mathrm{~F}_{0.25}(\mathrm{OH})_{0.02}\right]_{\Sigma 1.00}}\end{array}$ & [3] \\
\hline $\begin{array}{l}\text { Tmt6b } \\
\text { (chromo-alumino-povondraite) }\end{array}$ & 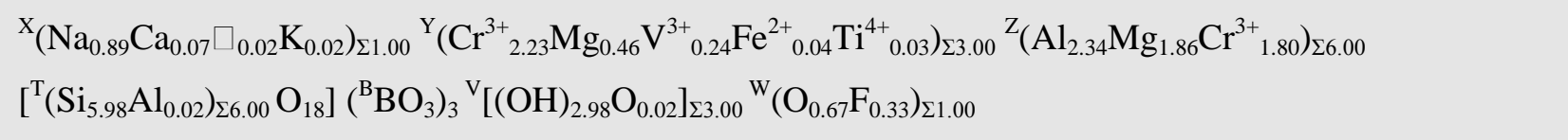 & [4] \\
\hline $\begin{array}{l}\text { T89104 } \\
\text { (oxy-chromium-dravite) }\end{array}$ & 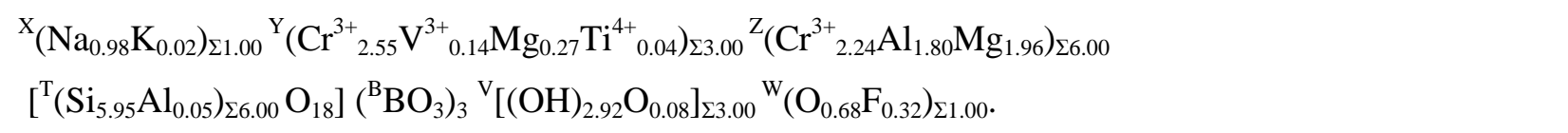 & [1] \\
\hline
\end{tabular}

Note: Minor deviations in the amounts of $\mathrm{O}$ and $\mathrm{OH}$ at the $V$ and $W$ positions may occur due to disordering effects (see text).

[1] = present study, [2] = Bosi et al. (2013), [3] = Reznitskii et al. (2014), [4] = Bosi et al. (2004) 
Table 9 Sample thicknesses and relative peak area intensities for infrared $(\mathbf{E} \perp \mathbf{c})$ and Raman (E // c) bands.

\begin{tabular}{|c|c|c|c|c|c|c|}
\hline Sample & PR108 & PR107 & PR85v & Tm1p43e & Tmt6b & T89104 \\
\hline Thickness $(\mu \mathrm{m})$ & 48 & 47 & 26 & 45 & 50 & 41 \\
\hline \multicolumn{7}{|c|}{ Infrared-bands } \\
\hline PAI (\%) 3519 & 29 & 56 & 73 & 71 & 79 & 90 \\
\hline PAI (\%) 3565 & 71 & 44 & 27 & 29 & 21 & 10 \\
\hline \multicolumn{7}{|c|}{ Raman-bands } \\
\hline PAI (\%) 3520 & - & $60^{\mathrm{a}}$ & 62 & 60 & - & 82 \\
\hline PAI (\%) 3556 & - & $40^{\mathrm{a}}$ & 38 & 40 & - & 18 \\
\hline
\end{tabular}

$\mathrm{PAI}=$ Fitted relative peak area intensity for the vibrational-bands

${ }^{\mathrm{a}}$ Large fitting error $(\sim 15 \%)$ 